\title{
Wolność ekspresji artystycznej. Regulacje europejskie a rozwiązania polskiego systemu prawnego
}

Ochrona uczuć religijnych jest wartością osadzoną w treści art. 25 ust. 1-3 oraz w art. 53 ust. 1-7 Konstytucji. Pozostawać ona może jednak w antynomii do innych wolności konstytucyjnych, w tym wolności prasy i innych środków społecznego przekazu (art. 14 Konstytucji), wolności słowa (art. 54 ust. 1 Konstytucji) i wreszcie wolności twórczości artystycznej, badań naukowych oraz ogłaszania ich wyników, wolności nauczania i wolności korzystania z dóbr kultury. $Z$ treści art. 73 Konstytucji wywodzi się wolność ekspresji artystycznej, widząc dodatkową gwarancję tej wolności w przepisie art. 54 ust. 1 Konstytucji, zapewniającym wolność wyrażania swoich poglądów oraz rozpowszechniania informacji. Pod pojęciem rozpowszechniania informacji należy także niewątpliwie rozumieć prezentację działań artystycznych. Gwarancją możliwości takowej prezentacji zdaje się być dyspozycja art. 54 ust. 2 Konstytucji, w którym sformułowano zakaz cenzury prewencyjnej. Rozstrzygnięcie wspomnianej antynomii jest zadaniem trudnym, ale możliwym do przeprowadzenia.

Ekspresja artystyczna towarzyszy - jak się wydaje - człowiekowi od zarania dziejów. Sztuka stanowiła zawsze immanentną część kultury i cywilizacji. Bez sztuki bardzo trudno byłoby zrozumieć nie tylko życie prywatne w poszczególnych epokach, dzieje kultury, a nawet historię gospodarczą i polityczną. Sztuka zdaje się nie znać granic geograficznych i chronologicznych. Stale poszerza swój zasięg, obejmując kulturę, religię, systemy polityczne, zawłaszcza gospodarkę, stymulując zachowania rynkowe, tworząc nowe zawody, zapewniając utrzymanie rzeszom pracowników, którzy w prawdzie sami sztuki nie tworzą, ale nią administrują, konserwują jej dzieła, zbierają związane z nią przekazy, handlują nimi. Praktycznie od początku swojego istnienia sztuka wydaje się być związana z religią, którą częstokroć wyraża oraz z prawem. To ostatnie stara się z jednej strony zdefiniować pojęcie sztuki, z drugiej wyznaczyć jej granice. Przekonaniu artystów, że sztuka jest wolna i nie pod- 
lega żadnej reglamentacji, towarzyszą stale podejmowane próby wyznaczenia dopuszczalnych prawnie sposobów i form ekspresji. W gruncie rzeczy od starożytności po dzień dzisiejszy zauważyć można mniej lub bardziej świadomą walkę o wolność sztuki. Motywy, jakimi kierują się władze publiczne, starając się swobodę tę ograniczyć, mają różne źródła i same przez się zasługują na pogłębioną analizę socjologiczną. Najczęściej wynikają z przyczyn religijnych, osadzone są w pewnych schematach kulturowych, przyzwyczajeniach estetycznych. Według teologów i kapłanów reprezentujących różne religie, sztuka może obrażać uczucia religijne wiernych, podważać dogmaty, ośmieszać symbole. Zdaniem polityków, zwłaszcza w systemach autorytarnych, sztuka winna służyć państwu, zmierzać do konsolidacji jego obywateli, wyrażać treści aprobowane przez rządzących. W myśl tej koncepcji artysta powinien identyfikować się z reżimem politycznym, służąc mu wiernie i z przekonaniem. Oczywiście są całe rzesze artystów, często niezwykle utalentowanych, którzy gotowi są spełnić zapotrzebowanie czynników religijnych bądź politycznych, tworzyć na zamówienie, które chociaż bywa określane mianem zamówienia społecznego, jest w istocie zamówieniem, które wypływa z kanonów estetycznych, przyjętych za właściwe przez zwierzchników politycznych bądź religijnych. Kanony te, z racji posiadanej władzy, potrafią oni narzucić społeczeństwu jako jedynie możliwe do akceptacji.

Twórczość artystyczna charakteryzuje się jednak tym, że nie daje się łatwo tłoczyć schematom. Artyści zwykle wyprzedzają swoją epokę i to czasem o wiele lat. Dzieła, które tworzą, prowokują, częstokroć szokują, godzą w przyzwyczajenia. Artysta wyrażając swoje przeżycia, dając upust żywionym uczuciom, chce jednak zdobyć uznanie społeczeństwa, przekonać do prezentowanej wizji, czasem narzucić swój odbiór rzeczywistości. Poeta i powieściopisarz może przez lata pisać do przysłowiowej ,szuflady”, nie mając widoków na publikację swoich dzieł - chociaż dzisiaj, w dobie internetu, możliwe okazało się udostępnienie takich utworów w formie elektronicznej. Rzeźbiarz, malarz, twórca filmowy, pożądają publiczności, w ekshibicjonistyczny sposób obnażają swoje uczucia, z wewnętrznym masochizmem spodziewając się bicza krytyki - licząc jednak, że jego duchowe cierpienie nie będzie daremne, że przekona do swoich wizji artystycznych.

Określenie w treści art. 73 Konstytucji wolności twórczości artystycznej, podobnie z resztą jak i badań naukowych, nakłada na władze publiczne zakaz podejmowania działań utrudniających lub przekreślających swobodę prowadzenia badań naukowych, wolność twórczości artystycznej oraz wolność ogłaszania wyników badań. Obowiązki te mają charakter negatywny, gdyż przedmiotem ich jest wolność ${ }^{1}$. W Konstytucji nie sformułowano nato-

${ }^{1}$ W doktrynie, a jeszcze częściej w procesie legislacyjnym, utożsamia się pojęcia „wolności” i ,„praw” jednostki. Czasami traktuje się te terminy jako synonim obowiązku. Wskazuje się jednak na to, że między kategoriami „,wolność” i ,prawo” występują różnice i dlatego nie jest właściwe za- 
miast żadnych pozytywnych obowiązków władz publicznych w odniesieniu do badań naukowych oraz do ludzi podejmujących takie badania. Władze te same, według przyjętych przez siebie kryteriów, mogą określać więc zasady przyznawania środków na prowadzenie badań naukowych, publikacje oraz określać skład zespołów badawczych - pod warunkiem, że nie naruszają one wspomnianej wyżej autonomii szkół wyższych.

Zadeklarowanie w Konstytucji wolności ekspresji artystycznej nie oznacza jednak, że ma ona charakter absolutny i nie może podlegać prawnym ograniczeniom. W doktrynie od dawna poszukiwano granic wolności, wskazując, że mogą one mieć charakter: aktualny i potencjalny, w zależności od tego, czy istnieją w chwili obecnej, czy też mogą wystąpić w przyszłości; przekraczalny, czyli dający się usunąć i nieprzekraczalny, czyli taki, którego nie można lub nie powinno się usuwać; zewnętrzny wobec podmiotu i wewnętrzny, wbudowany w psychikę podmiotu; normatywny i faktyczny. Wśród ograniczeń faktycznych, jako wewnętrzne granice wolności wskazuje się najczęściej zdolności i umiejętności człowieka, a wśród zewnętrznych - sytuacje (konflikty interesów, sploty okoliczności, ograniczone zasoby) oraz działania intencjonalne innych ludzi (groźby, naciski, arbitralne dyrektywy). Wśród ograniczeń normatywnych wskazuje się granice wewnętrzne w postaci wybranych przez podmiot norm moralnych oraz zewnętrzne (prawo, obyczaje, moralność). Za-

mienne ich używanie, a także posługiwanie się ich swoistą ,zbitką”, na przykład: prawo do wolności osobistej, prawo do wolności sumienia i wyznania. Wskazuje się, że akt normatywny dotyczący wolności powinien mieć formę normy deklarującej wolność (jednak nie kreującej jej, gdyż wolność ma charakter przyrodzony), wyczerpująco wymieniać ograniczenia wolności w formie zakazów, nakazów oraz sankcji, wreszcie gwarantować prawnie, instytucjonalnie i materialnie możliwości realizacji wolności w części nie podlegającej ograniczeniom. „Prawo człowieka” ma charakter roszczenia do świadczenia ustalonego w akcie normatywnym. Powstaje ono z chwilą wejścia w życie normy prawnej, kreującej to prawo, nie jest więc prawem przyrodzonym i niezbywalnym. Akt normatywny tworzący prawo jednostki powinien określać treść tego prawa oraz gwarantować realność prawa i możliwość jego dochodzenia przed organami administracyjnymi i sądowymi. Konsekwencją rozróżnienia „wolności” jednostki od „prawa” jednostki jest to, iż obywatel, realizując swoje wolności, nie musi szukać w obowiązującym prawie zezwolenia, lecz jedynie ograniczenia wolności. Ustawa musi wyczerpująco określać zakres prawa albo precyzyjnie statuować zakazy, gdy reguluje sprawę wolności. Organy państwa, odnosząc się do sprawy z zakresu wolności, nie mogą wydawać decyzji o charakterze zezwolenia, a jedynie rejestrować to, o czym zadecydował obywatel. W przypadku praw obywatela państwo przyznaje obywatelowi uprawnienia rodzące określone roszczenia, przyjmując na siebie obowiązek działań zapewniających realizację tych roszczeń. W przypadku wolności obywatelskich państwo sankcjonuje sferę działania jednostki wolną od ingerencji państwa, biorąc na siebie obowiązek zagwarantowania swobody działania w ramach zakreślonych przez prawo przedmiotowe. W odróżnieniu od praw i obowiązków, wolności obywatelskie charakteryzują się nałożeniem przez prawo przedmiotowe na obywatela nakazu lub zakazu określonego w postępowaniu. Jednocześnie państwo powinno zapewnić warunki umożliwiające obywatelowi wywiązanie się z nałożonych na niego obowiązków. Por. L. Wiśniewski, Prawo a wolność człowieka - pojęcie i konstrukcja prawna, [w:] Podstawowe prawa jednostki i ich sądowa ochrona, red. L. Wiśniewski, Warszawa 1997, s. 51 nn.; Prawa czlowieka, geneza, koncepcje, ochrona, red. B. Banaszak, Wrocław 1993. 
uważa się, że granice wolności mogą się wzajemnie redukować, przy czym zewnętrzne wobec podmiotu fakty ograniczające jego wolność dzieli się na behawioralne (oparte na intencjonalnych zachowaniach innych ludzi) i sytuacyjne (spontaniczne i obiektywne istniejące w rzeczywistości) ${ }^{2}$. W sensie filozoficznym przyjmuje się zazwyczaj, iż granicą wolności jest dobro osoby ludzkiej i stwierdza, iż granicą wolności jednostki jest wolność innego człowieka. Uważa się, iż wolność jest atrybutem i prawem każdego człowieka również w wymiarze społecznym. Zwraca się jednak uwagę na możliwości nadużycia wolności zarówno w płaszczyźnie osobisto-indywidualnej, jak i społecznej. Ta ostatnia kwestia szczególnie silnie podkreślana jest w nauce społecznej Kościoła katolickiego, w ramach której zauważa się, iż skrajny indywidualizm i liberalizm słusznie bronią wolności każdego człowieka, ale oba te nurty izolują wolność od całości ludzkiej osoby i właściwych jej wartości. Podnosi się, iż wolność jest prawem i szansą każdego człowieka, ale powinna to być wolność odpowiedzialna, służąca dobru człowieka i jego osoby33.

Granice tej wolności niewątpliwie określa art. 31 Konstytucji, zwłaszcza w ust. 3, ale również w ust. 2. Analizując treść tych przepisów, warto pamiętać, że adresatem ich jest władza publiczna rozumiana jako zbiór podmiotów, które wykonują kompetencje władcze, bądź przygotowują lub organizują wykonywanie tych kompetencji ${ }^{4}$. Wśród wymienionych $\mathrm{w}$ treści art. 31 ust. 3 Konstytucji przesłanek materialnych ograniczeń w zakresie korzystania w zakresie konstytucyjnych wolności i praw, których katalog ma charakter wyczerpujący, szczególnie ważne w odniesieniu do badań naukowych wydają się te, które są konieczne dla bezpieczeństwa lub porządku publicznego, zdrowia i moralności publicznej. Mniejsze znaczenie będą miały - co nie oznacza, że zupełnie nie wystąpią - ograniczenia odnoszące się do ochrony środowiska oraz wolności praw innych osób. Należy zauważyć, że tak czy inaczej, wszystkie ewentualne ograniczenia mogą być ustanawiane i wprowadzane tylko i wyłącznie wtedy, gdy są konieczne w demokratycznym państwie. W literaturze zwraca się uwagę na trudności, jakie rodzą określenia: ,przesłanki bezpieczeństwa państwa” oraz „przesłanki bezpieczeństwa publicznego"5.

2 Por. W. Lamentowicz, O wolnościach i ich granicach, [w:] Historia. Idee. Polityka, księga dedykowana profesorowi Janowi Baszkiewiczowi, red. F. Ryszka, Warszawa 1995, s. 396 nn.

3 Por encykliki: Centessimus annus i Veritatis splendor. Zob. także: St. Kowalczyk, Wolność natura i prawem człowieka, Sandomierz 2000, s. 26; idem, Koncepcja wolności odpowiedzialnej $w$ encyklice Veritatis Splendor Jana Pawła II, [w:] Wolność we współczesnej kulturze. Materiały V Światowego Kongresu Filozofii Chrześcijańskiej KUL - Lublin 20-25 sierpnia 1996, Lublin 1997, s. 331-339; S. Karasek, Koncepcja wolności w encyklice ,, Veritatis splendor” Jana Pawła II, Lublin 1994, s. 37-65.

${ }^{4}$ L. Garlicki, Komentarz do art. 30 Konstytucji [w:] Konstytucja Rzeczypospolitej Polskiej. Komentarz, red. L. Garlicki, t. III, Warszawa 2003, s. 19.

${ }^{5}$ K. Wojtyczek, Granice ingerencji ustawodawczej $w$ sfere praw człowieka $w$ Konstytucji RP, Kraków 1991, s. 183; M. Wyrzykowski, Granice praw i wolności-granice władzy, [w:] Obywatel, jego wolności i prawa, oprac. B. Oliwa-Radzikowska, Warszawa 1998, s. 50. 
Wskazuje się, iż pod pojęciem „porządek publiczny” należy rozumieć takie ukształtowanie stosunków społecznych wewnątrz państwa, które umożliwia normalne współżycie jednostek ${ }^{6}$.

Zauważana antynomia istnieje nie tylko na gruncie polskiego prawa konstytucyjnego, lecz także w płaszczyźnie systemu prawnego Rady Europy na tle treści art. 9 ust. 1 stojącego na straży wolności myśli, sumienia i wyznania oraz art. 10 chroniącego wolność wyrażania opinii ${ }^{7}$. Jeszcze mocniej akcentuje ją Karta Podstawowych Praw Unii Europejskiej, której art. 10 chroni wolność myśli, sumienia i wyznania, art. 11 wolność wypowiedzi i informacji, a art. 13 wolność sztuk i nauk ${ }^{8}$.

Na tle treści art. 9 Europejskiej Konwencji Praw Człowieka zauważono, że wolność gwarantowana tym przepisem musi zezwalać na otwartą debatę w kwestiach odnoszących się do religii i przekonań z uwzględnieniem, że nowoczesne społeczeństwo składa się z osób różnych wyznań. Podniesiono, że ataki na poszczególne osoby ze względu na wyznawaną przez nich religię są niedopuszczalne, ale ewentualne bluźnierstwa nie mogą być wykorzystywane do ograniczenia wolności słowa i myśli. Różnorodność kulturowa Europy winna stać się źródłem wzajemnego wzbogacenia, a nie napięć. Podkreślono, że prawo dozwalające karanie za bluźnierstwo, krytykę praktyk religijnych i dogmatów miało w przeszłości negatywny wpływ na postęp naukowy i społeczny. Dodano, że w społeczeństwie demokratycznym, wspólnoty religijne mają prawo bronić się przed krytyką czy kpinami, zgodnie ze standardami praw człowieka, jednak satyra, humor i artystyczna wypowiedź winny korzystać z szerszej swobody, a przesada w tym względzie nie może być dostrzegana jako prowokacja. Niedopuszczalna jest przy tym mowa nienawiści przeciwko żadnej z istniejących grup religijnych. Debata na temat wolności słowa i szacunku dla przekonań religijnych winna się odbyć - jak wskazano w rezolucji - we wszystkich parlamentach Państw Członkowskich. Konieczne jest przy tym przedstawienie przez wspólnoty religijne innym zasad swej wiary tak, aby możliwe było wzajemne zrozumienie. Zgromadzenie zachęciło do dialogu międzykulturowego i międzyreligijnego $\mathrm{w}$ oparciu o uniwersalne prawa człowieka, zachęcając organy Rady Europy do aktywnego działania $\mathrm{w}$ sprawie zapobiegania szerzenia nienawiści, skierowanej pod ad-

${ }^{6}$ Wyroki Trybunału Konstytucyjnego: z 12 stycznia 1999 r., sygn. P 2/98; z 12 stycznia 2000, P11/99; z 7 lutego 2001 r. K27/00, OTK ZU 2001, Nr 2, poz. 29, s. 162-163.

${ }^{7}$ W kwestii tej zob. L. Garlicki, Uwagi do art. 9 i 10 Konwencji o Ochronie Praw Człowieka i Podstawowych Wolności, [w:] Konwencja o Ochronie Praw Czlowieka i Podstawowych Wolności, red. L. Garlicki, t. I, Warszawa 2010, s. 550-649.

${ }^{8}$ J. Sobczak, W. Sobczak, Uwagi do art. 10 Karty Praw Podstawowych Unii Europejskiej, [w:] Karta Praw Podstawowych Unii Europejskiej, red. A. Wróbel Warszawa 2013, s. 346-420, J. Sobczak, Uwagi do art. 11 Karty Praw Podstawowych Unii Europejskiej, [w:] Karta Praw Podstawowych..., s. 421-477; J. Sobczak, Uwagi do art. 13 Karty Praw Podstawowych Unii Europejskiej, [w:] Karta Praw Podstawowych..., s. 500-550. 
resem różnych grup etnicznych i religijnych. Efektem tego stanowiska było zalecenie (rekomendacja) 1805 (2007) w sprawie bluźnierstwa, znieważania religii i mowy nienawiści przeciwko jednostkom z powodu ich wyznania, przyjęte w dniu 29 czerwca $2007 \mathrm{r}$. W teście tego dokumentu stwierdzono, że w wielokulturowych społeczeństwach istnieje potrzeba pogodzenia wolności ekspresji, myśli, przekonań i religii. Musi to być jednak konieczne w demokratycznym społeczeństwie i proporcjonalne do przyjętych celów. Zdaniem Zgromadzenia, bluźnierstwo jako obraza religii nie powinno być uznawane za przestępstwo. Jest przy tym oczywiste, że w demokratycznym społeczeństwie grupy religijne, podobnie jak wszelkie inne, muszą tolerować krytyczne publiczne wypowiedzi, dotyczące ich aktywności, nauk i wierzeń, z tym, że krytyka ta nie może prowadzić do celowych i nieuzasadnionych zniewag, mowy nienawiści oraz powodować zakłócenia spokoju, przemocy czy dyskryminacji członków danej grupy wyznaniowej. Konieczne jest, aby członkowie społeczeństwa wiedzieli wiele o swoich religiach, gdyż wtedy mniej prawdopodobnym okaże się zniewaga, wywodząca się z ignorancji. Zauważono, że prawa $\mathrm{w}$ poszczególnych krajach i praktyka sądowa odnośnie bluźnierstwa i zniewagi wyznania odzwierciedlała dominującą pozycję określonej religii w jakimś państwie. Podkreślono, że prawo do wolności religijnej, gwarantowane przez art. 9 Konwencji, chroni religię w ten sposób, że nie pozwala atakować wartości cennych dla wyznawców. W końcu zalecono, aby Komitet Ministrów Rady Europy zachęcił rządy Państw Członkowskich do ratyfikacji Protokołu 12 Europejskiej Konwencji Praw Człowieka i spowodował depenalizację bluźnierstwa w ustawodawstwach krajowych.

Działalność artystyczna może rodzić poważne zagrożenia dla innych naruszając ich godność, prywatność, wolność sumienia i wyznania. Wolność ekspresji artystycznej nie miałaby żadnej doniosłości społecznej, gdyby nie towarzyszyła jej wolność nauczania i korzystania z dóbr kultury. Kwestie zakresu wolności ekspresji artystycznej stały się także przedmiotem licznych orzeczeń Europejskiego Trybunału Praw Człowieka w Strasburgu. Europejski Trybunał wielokrotnie podkreślił, że ochroną swobody wypowiedzi, wynikającą z art. 10 Europejskiej Konwencji, objęte są wszystkie rodzaje ekspresji wyrażające opinie, idee lub informacje niezależnie od ich treści oraz sposobu komunikowania ${ }^{9}$.

9 Orzecznictwo Europejskiego Trybunału Praw Człowieka w tym zakresie było wielokrotnie analizowane w doktrynie zob. m.in. J. Sobczak, Wolność sztuki, twórczości artystycznej i satyry. Czy istnieje kontratyp sztuki? Regulacje europejskie a rozwiąania polskiego systemu prawnego, [w:] Uniwersalny i regionalny wymiar ochrony praw człowieka. Nowe wyzwania - nowe rozwiazania, red. J. Jaskiernia, t. III, Warszawa 2014, s. 360-370; idem, Wolność środków spolecznego przekazu czy wolność ekspresji w orzecznictwie Trybunalu Sprawiedliwości w Strasburgu, [w:] Kulturowe instrumentalium wolności. Etyka i prawo, red. R. Paradowski, Poznań 2015, s. 163-208; tenże, Wolność ekspresji artystycznej. Standardy europejskie i rzeczywistość polska, [w:] Rada Europy a przemiany demokratyczne w państwach Europy Środkowej $i$ Wschodniej w latach 1989- 
Szczególnym rodzajem ekspresji artystycznej jest satyra, będąca swoistą krytyką poszczególnych ludzi bądź całych grup społecznych, zwyczajów, obyczajów, postaw światopoglądowych, artystycznych, zmierzająca do napiętnowania wad i przywar ${ }^{10}$. Wyjątkowo wdzięcznym obiektem działań satyrycznych staje się polityka i politycy. Im bardziej ci ostatni gotowi traktować się serio, tym chętniej, celniej i z większą zjadliwością gotowi uderzać w nich satyrycy. W literaturze podkreśla się, że istotą wypowiedzi satyrycznych jest negacja, chętnie posługująca się środkami komicznej deformacji: groteską, dowcipem, ironia, kpiną i szyderstwem. Twórca satyry pozornie nie przedstawia wzoru pozytywnego, nie formułuje programów, nie wskazuje ideałów, nie określa wzorów i standardów ${ }^{11}$. Niemniej program pozytywny wbrew pozorom w satyrze także istnieje, ale na ogół jest on głęboko ukryty. To raczej odbiorca utworu satyrycznego ma niejako samodzielnie, przyjmując za swoje negatywne oceny twórcy satyry dojść do aprobowanych, choć nieformułowanych bezpośrednio przez satyryka wniosków. Na tym właśnie zasadza się moc satyry, na tym polega jej niebezpieczeństwo dla jednostek i grup osób, które stały się obiektem satyrycznego przekazu - żeby nie powiedzieć: ataku. Dlatego też utwory satyryczne tak chętnie odbierane są przez społeczeństwo i z taką zajadłością zwalczane przez tych, którzy zostali dotknięci ich ostrzem.

Zjawisko satyry pojawia się już w starożytności, a utwory satyryczne pisano nawet w starożytnej Grecji ${ }^{12}$. Do XVIII w. satyra była traktowana jako

-2009, red. J. Jaskiernia, Toruń 2010, s. 612-630; idem, Wolność ekspresji artystycznej, [w:] Media - czwarta władza?, red. M. Gołda-Sobczak, W. Machura, J. Sobczak, t. 2, Poznań-Opole 2011, s. 397-420. Por. także I. C. Kamiński, Ograniczenia swobody wypowiedzi dopuszczalne w Europejskiej Konwencji Praw Człowieka. Analiza krytyczna, Warszawa 2010, s. 399 nn. M. Skwarzyński, Bluźnierstwo w świetle standardów ochrony praw człowieka, [w:] Odpowiedzialność karna artysty za obrazę uczuć religijnych, red. F. Ciepły, Warszawa 2014, s. 95-107. Wspomnieć jedynie wypada o orzeczeniach w sprawach: Handyside przeciwko Wielkiej Brytanii, skarga nr 5493/72, wyrok z dnia 7 grudnia 1976 r., http://hudoc.echr.coe.int/eng?i=001-57499, [dostęp: 13.11.2015, 18:41]; Otto-Preminger-Institut przeciwko Austrii, wyrok z dnia 20 września 1994 r., skarga nr 13470/87, http://hudoc.echr.coe.int/eng?i=001-57897, [dostęp: 13.11.2015, 18:43]; Sunday Times przeciwko Wielkiej Brytanii, wyrok z dnia 26 kwietnia 1979 r., skarga nr 6538/74, http://hudoc.echr. coe.int/eng?i=001-57584, [dostęp: 13.11.2015, 18:45]; Müller i inni przeciwko Szwajcarii, wyrok z dnia 24 maja 1988 r., skarga $\mathrm{nr}$ 10737/84, http://hudoc.echr.coe.int/eng?i=001-57487, [dostęp: 13.11.2015, 18:50]; Wingrove przeciwko Wielkiej Brytanii, wyrok z dnia 25 listopada 1996 r., skarga nr 17419/90, http://hudoc.echr.coe.int/eng?i=001-58080, [dostęp: 13.11.2015, 18:53]; Hachette Filipacchi Associés przeciwko Francji, wyrok z dnia 12 listopada 2007 r., skarga nr 71111/01, http:// hudoc.echr.coe.int/eng?i=001-81066, [dostęp: 13.11.2015, 18:55].

${ }^{10}$ I.I.H. Dee, Satyra jako gra retoryczna, [w:] Nowa proza amerykańska. Szkice krytyczne, Warszawa 1983, s. 38; J. Elsberg, Woprosy tieorii satiry, Moskwa 1957, passim; Literatura polska. Przewodnik encyklopedyczny, t. II, Warzsawa 1985, s. 338.

${ }_{11}$ M. Głowiński, A. Okopień-Sławińska, J. Sławiński, Zarys teorii literatury, Warszawa 1986, s. 436-438; A. Bereza, Problemy teorii stylizacji w satyrze, Warszawa 1966, s. 17 nn.; R.C. Ellliot, The Power of Satire, Princeton 1960, passim; G. Mighet, The Anatomy of Satire, Princeton 1962, passim.

12 Przykładem zjadliwej satyry politycznej są komedie Arystofanesa, a satyry wymierzonej w wierzenia i urządzenia społeczne dzieła Meniposa z Gadary. Pojęciem „satyra” (saturae) jako 
odrębny gatunek literacki, ,pozostając poza klasyfikacją genealogiczną, we wszystkich typach ekspresji nie mieszczących się w tym gatunku" "W. Współcześnie satyra nie stanowi już odrębnego rodzaju ani gatunku literackiego. Może pojawiać się zarówno w wypowiedziach lirycznych, epickich, utworach dramatycznych, zwłaszcza w komediach, poematach, opowiadaniach, bajkach, epigramatach, felietonach, szopkach, monologach, skeczach, kupletach, piosenkach i w tzw. „kawałach"14. Od lat trwają spory o definicję satyry ${ }^{15}$, chociaż współczesne encyklopedie i słowniki formułują ją w zbliżony sposób $^{16}$. Zauważa się, że obecnie satyra to zarówno utwory literackie, a także ra-

pierwszy posłużył się Quintus Ennius na przełomie III i II w. p.n.e. Za właściwego twórcę tego gatunku w literaturze rzymskiej uważa się jednak Calusa Lucyliusa, autora zbioru Saturarum libri, który ustalił charakter i miarę wierszowaną. Utwory Lucyliusza - gorzkie i niekiedy złośliwe, osobiste w treści - wymierzone były w polityczno-społeczne nieprawidłowości. To dzięki niemu satyra rzymska stała się odrębną formą gatunkową, przybierając charakter ,pouczającego lub napastliwego utworu wierszowanego o własnych rygorach kompozycyjnych, stylistycznych i wersyfikacyjnych, będącego monologiem, dialogiem lub narracją na tematy obyczajowe, polityczne lub literackie". Literatura polska, red. J. Krzyżanowski, Cz. Hernas, Warszawa 1985, s. 338. Przedstawicielami satyry rzymskiej byli Marek Terentius Varro, Quintus Horatius Flaccus, Decimus Junius Juvenalis. Satyra odznaczała się na początku rozmaitością formy. Od czasów Horacego zasadniczo jednak ujmowana była w miarę heksametru.

${ }_{13}$ Slownik terminów literackich, red. J. Sławiński, Wrocław 1988, s. 457.

${ }^{14}$ Zob. A. G. Bem, Teorya poezji polskiej z przykladami w zarysie popularnym analitycznodziejowym, Petersburg 1989, s. 15; F. Pruchnicki, Lwów 1920, s. 82; H. Galle, Stylistyka i teorya literatury, Warszawa 1915, s. 4; B. Tomaszewski, Poetyka, Poznań 1935, s. 18; H. Cegielski, Nauka poezji, Poznań 1879, s. 115; S. Skwarczyńska, O pojęciu literatury stosowanej, [w:] Szkice i felietony, „Rocznik Literacki”, Warszawa 1937-1938; M. Promiński, Gorzkie migdały poezji, „Kurier Literacko - Naukowy”, 1936, nr 28; M. R. Mayenowa, Poetyka opisowa, Warszawa 1949, s. 13; K. Brodziński, Pisma estetyczno-krytyczne, Wrocław 1964, s. 32.

${ }^{15}$ Według Ignacego Chrzanowskiego: „trzy główne pierwiastki składają się na satyrę: dydaktyczny - pod postacią moralizacyj, liryczny - pod postacią uczucia autora, epiczny, który się objawia już to jako opowiadanie o jakiemś zdarzeniu, już to jako obrazowa i żywa charakterystyka danej postaci. Od sposobu wykonania każdej z tych rzeczy, części składowych satyry oraz wzajemnego ich stosunku zależy jej wartość artystyczna. Kiedy moralizacja jest sucha, uczucia wypowiedziane słabo lub nieszczerze, a opowiadanie bez plastyki i życia, wówczas satyra nie ma wartości, niewiele posiada i wtedy, gdy pierwszy pierwiastek dusi dwa drugie, wówczas bowiem satyra przestaje być poezyją i staje się prozą dydaktyczną".

$16 \mathrm{~W}$ przedwojennym słowniku M. Artcta: satyra to ,utwór prozą lub wierszem potępiający, wyszydzający lub z lekka ośmieszający przywary, wady i nałogi ludzkie. To wyszydzanie wszelkiej śmieszności z humorem i dowcipem”, M. Arct, Słownik wyrazów obcych, Warszawa 1938. Późniejsze słowniki i encyklopedie przytaczają zbliżone definicje tego pojęcia. W myśl Słownika wyrazów obcych: „Satyra (łac. satira) to utwór literacki ośmieszający wady i przywary ludzkie, sposoby postępowania i poglądy, obyczajowość, stosunki polityczne i społeczne”, por. Stownik wyrazów obcych PWN, Warszawa, 1978. Niemal identycznie definiuje satyrę Stownik języka polskiego, red. M. Szymczak, t. III, Warszawa 1989, s. 182, a także Uniwersalny stownik języka polskiego red. S. Dubisz, t. III, Warszawa 2003. Z kolei Wielka Encyklopedia Powszechna: „,satyra to utwór literacki będący wyrazem krytycznego stanowiska autora wobec rzeczywistości społecznej, ośmieszający lub nawet piętnujący przedstawione zjawiska, wady i przywary ludzkie, obyczajowość, stosunki socjalne, postawy i orientacje polityczne, sposoby postępowania i poglądy", zob. Wielka Encyklopedia Powszechna, t. X, Warszawa 1967, s. 370. Identyczną definicję przynosi tom XXIV Wielkiej 
diowe i telewizyjne programy rozrywkowe ${ }^{17}$. Satyryczny charakter miewają często anonimowe wierszowane hasła na murach ${ }^{18}$. Nośnikiem satyry bywają programy kabaretowe, przedstawienia teatralne ${ }^{19}$. Od satyry nie są wolne nawet reklamy, a umiejętne posługiwanie się nią zwiększa atrakcyjność takich przekazów ${ }^{20}$.

Encyklopedii Powszechnej PWN, Warszawa 2004. Niekiedy, nie definiując satyry, podkreśla się, że pojęcie to bywało różnie rozumiane w różnych okresach literackich. Zauważa się, że w okresie oświecenia termin ten „funkcjonował przede wszystkim jako nazwa gatunku literackiego, który obejmował utwory poetyckie prezentujące wyjaskrawiony obraz uznanych za szkodliwe zjawisk rzeczywistości społecznej (postaw politycznych, obyczajów, wad i przywar ludzkich) i realizujące przy tym utrwalone długą tradycją normy kompozycyjno-stylistyczne, a nawet wersyfikacyjne". Tak widzą satyrę polskiego oświecenia M. Grzędzielska i T. Kostkiewiczowa. Por. Slownik literatury polskiego Oświecenia, wyd. II, Wrocław-Warszawa-Kraków 1996, s. 554, E. Wróblewska w odniesieniu do literatury polskiej XIX w. podkreśla jedynie, że satyra tego okresu przyjęła wiele wzorów wypracowanych w dobie oświecenia przez najwybitniejszych przedstawicieli tego gatunku. Jednak zatraciła właśnie w XIX w. charakter odrębnego gatunku literackiego, występując w różnych formach liryki, epiki czy dramatu, bądź jako element zasadniczy, bądź - poboczny. Zob. Stownik literatury polskiej XIX wieku, red. J. Bachusz, A. Kowalczykowa, Wrocław-Warszawa-Kraków 1997 , s. 862-863. Zwykle wskazuje się, iż podstawy nowego, ponadgatunkowego rozumienia satyry zostały zawarte w rozprawie K. Brodzińskiego O satyrze, Warszawa 1822.

17 T. Stępień, O satyrze, Katowice 1996, s. 7.

18 Zob. J. Sobczak, P. Piesiewicz, Graffiti - dzieło sztuki czy forma dewastacji obiektów architektonicznych, [w:] Street art. Między wolnościq a anarchiq, red. M. Duchowski, E.A. Sekuła, Warszawa 2011, s. 58-68; J. Dąbrowski, „, The medium is the message” - graffiti writing jako McLuhanowski środek przekazu, [w:] Street art..., s. 32-57; C. Lewisohn, Street Art.: The Graffiti Revolution, Tate Publishing 2008.

${ }^{19}$ Utwory satyryczne pojawiały się w dziejach literatury polskiej zarówno w okresie staropolskim, jak i w dobie odrodzenia, w czasach saskich, oświecenia, kiedy to gatunki satyryczne rozwijały się szczególnie bujnie, a także w późniejszych okresach literackich. Jednak poważniejszych analiz doczekała się satyra tylko w niektórych z tych epok. Zob. I. Chrzanowski, Z dziejów satyry polskiej XVIII wieku, Warszawa 1909; A. Bereza, Problemy teorii stylizacji w satyrze, Wrocław 1966; P. Buchwald-Pelcowa, Satyra czasów saskich, Wrocław 1966, Z. Jastrzębski, Kpina i terror, „Teksty”, 1972, z. 3; Woźnikowski, Pamflet polityczny w czasach Stanisława Augusta, Wrocław 1973, J. Nowak-Dłużewski, Satyra polityczna Sejmu Czteroletniego, Warszawa 1933; idem, Satyra polityczna konfederaci targowickiej i sejmu grodzieńskiego, Warszawa 1935; W. Floryan, Satyry Kasickiego a Boi-Leau, [w:] Księga referatów zjazdu naukowego im. I. Krasickiego, Warszawa 1936; D. Hopensztand, Satyry Krasickiego, [w:] Stylistyka teoretyczna w Polsce, red. K. Budzyk, Warszawa 1946, s. 54; A. Aleksandrowicz, Twórczość satyryczna Adama Naruszewicza, Warszawa 1964, J. T. Pokrzywniak, J. Goryczewski. Thumacz, satyryk i krytyk; ,Satyra prawdę mówi” czyli rzecz o fatszywych przesłankach, „Pamiętnik Literacki”, 1984, z. 4, s. 57, M. Grzędzielska, T. Kostkiewiczowa, Satyra, [w:] Stownik literatury polskiego Oświecenia, red. T. Kostkiewiczowa, wyd. II, Wrocław-Warszawa-Kraków 1996, s. 594-560; E. Wróblewska, Satyra polityczna Wielkiej Emigracji, Poznań 1977; także: Satyra, [w:] Stownik literatury polskiej XIX wieku, red. J. Bachórz, A. Kowalczykowa, Wrocław-Warszawa-Kraków 1991, s. 862-867; S. Frybes, W krainie groteski. Problemy satyry galicyjskiej drugiej połowy XIX w., Warszawa 1979; E. Warzynica-Zalewska, Pojęcie humoru, jego rola w powieściopisarstwie polskim drugiej polowy XIX w., „Przegląd Humanistyczny", 1992, nr 6, s. 82.

20 O. Toscani, Reklama uśmiechnięte ścierwo, Warszawa 2009; A. Hordecka, Mitologiczny świat reklam, Kraków 2002, s. 55-110. Przykłady satyry w reklamie zob. materiał ilustracyjny R. Grochowski, Granice prawne i etyczne reklamy, Poznań-Opole 2010, s. 295, 299, 302. 
W teorii literatury podkreśla się, że satyra jest zjawiskiem ponadliterackim, interartystycznym i intersemiotycznym, funkcjonującym między szeroko rozumianą literaturą, plastyką i formami audiowizualnymi (estrada, film, radio i telewizja). Operuje ona tylko dwoma podstawowymi sposobami kształtowania rzeczywistości. Pierwszy z nich polega na przedstawianiu rzeczywistości w „krzywym zwierciadle” na drodze selektywnej, wybiórczej rejestracji krytykowanych aspektów otaczającego świata. Takim ujęciem rzeczywistości operowały staropolskie utwory satyryczne, a współcześnie większa część felietonów, wierszy lub piosenek. Drugi sposób kształtowania rzeczywistości wykorzystywany przez satyrę stanowi groteska, będąca posuniętą do skrajności deformacją rzeczywistości, kontrastująca jakości estetyczne wywołujące poczucie absurdu istnienia ${ }^{21}$. Satyra miała spełniać wiele funkcji, wśród nich - dydaktyczną, polityczną - definiowaną częstokroć jako funkcję walki ${ }^{22}$. Zauważa się, że funkcja dydaktyczna satyry z biegiem czasu zaczęła ustępować ludycznej, co prowadziło do zatarcia granicy między satyrą, komizmem a humorem ${ }^{23}$. Niektórzy zastanawiają się nad stosunkiem satyry do komizmu, podkreślając że o przynależności jakiegoś utworu do satyry decydują nie jego formalno-gatunkowe cechy, ale fakt agresywnego, bezkompromisowego dyskredytowania i ośmieszania w tym utworze zjawisk stanowiących jego przedmiot $^{24}$. Podejmowane są też próby odpowiedzi na pytanie czym satyra różni się od humoru ${ }^{25}$. Nie sposób się jednak oprzeć wrażeniu, że wynikające z tych

21 T. Stępień, O satyrze, s. 7 nn.

$22 \mathrm{~W}$ kwestii funkcji dydaktycznej satyry por. uwagi Jana Lemańskiego w przedmowie do książki J. Lemański, Satyra polska. Antologia, Warszawa 1958, s. 6. Na funkcję dydaktyczną zwraca uwagę zarówno Ignacy Krasicki pisząc: „I śmiech niekiedy moży być nauką”, jak i św. Augustyn zauważając: „miłość bliźniego nakazuje niekiedy śmiać się z błędów ludzi, aby ich samych skłonić do śmiania się z nich i unikania ich”, zob. S. Garczyński, Anatomia komizmu, Poznań 1989, s. 74-75.

23 T. Stępień, Zabawa, poetyka, polityka, Katowice 2002, s. 30.

24 Stanowisko takie prezentuje Bogdan Dziemidok, wyodrębniając komizm prosty (farsowowodewilowy) oraz komizm złożony, który dzieli na humorystyczny i niehumorystyczny. Satyrę jako przekaz zaangażowany społecznie, zwalczający zło z punktu widzenia określonych ideałów zalicza on do komizmu niehumorystycznego, czyli dezaprobującego. Jego zdaniem na miano ,,satyrycznego" zasługuje utwór, którym dominuje dążenia do agresywnego i bezkompromisowego dyskredytowania i ośmieszania. Utwory, w których takie elementy jedynie się ujawniają (ale nie dominują), nie są satyrą, a mogą mieć co najwyżej satyryczne zabarwienie. Zob. B. Dziemidok, O komizmie, Warszawa 1967, s. 92-94.

${ }^{25}$ Zob. H. Sawecka, Humor i satyra, [w:] Humor europejski, red. M. Abramowicz, D. Bertrand, T. Strużyński, Lublin 1994, s. 24. Według tej autorki satyra ma wywoływać pogardę dla złych i bezmyślnych, ulepszyć świat, przyjmując moralność jako probierz rzeczywistości. Ma charakteryzować się postawą krytyczną, nieugiętością, agresywnością, tropić słabości, ma uciekać się do porównań, operując parodią i karykaturą. Adresowana jest do osób skłonnych do krytykowania. Natomiast humor powinien wzbudzać zrozumienie i współczucie dla dziwacznych aspektów świata, winien być zdystansowany, przychylny, tolerancyjny i wyrozumiały, oparty na realistycznej obserwacji, preferujący opowiadania w pierwszej osobie, chętnie posługujący się dialektami i językami zawodowymi. 
prób systematyki podziały mają charakter czysto spekulacyjnych rozważań i niewiele wnoszą do istoty zagadnienia.

Satyra ma wiele odmian. Wskazuje się wśród nich satyrę literacką - wymierzoną w konwencję i szablony twórczości pisarskiej, chętnie uciekającą się do parodii, trawestacji, pastiszu i persyflarzu, satyrę społeczno-obyczajową - atakującą konkretne zwyczaje, niedomogi życia społecznego, przesądy, mody i snobizmy, satyrę osobistą - ośmieszającą w sposób aluzyjny lub wprost osoby powszechnie znane na forum publicznym (pełniące funkcje publiczne). Ten ostatni typ satyry chętnie odwołuje się do formy paszkwilu. Najistotniejszą rolę zdaje się odgrywać jednak satyra polityczna, skierowana przeciwko postaciom i instytucjom życia politycznego. Warto zauważyć, że pojęcie satyry politycznej nie zostało w literaturze zdefiniowane. Można natomiast zaryzykować stwierdzenie, że satyrą polityczną są wszelkie utwory (zwłaszcza literackie - w tym wiersze, piosenki, skecze, parodie, monologi, felietony, tzw. kawały; plastyczne - zwłaszcza rysunki, karykatury, fotomontaże; filmy, programy radiowe i telewizyjne), które w całości lub we fragmentach ośmieszają, wyszydzają, piętnują działalność władz państwowych, ich przedsięwzięcia, cele, formy działalności, zadania i metody realizacji tych zadań, a także wyszydzające konkretne osoby biorące czynny udział w życiu politycznym. Satyra polityczna w wielu przypadkach tożsama z satyrą osobistą $^{26}$. Jakkolwiek satyryczne utwory o charakterze politycznym chętnie są czytane, oglądane, powtarzane z ust do ust, to jednak dość szybko ulegają zapomnieniu, ponieważ po wielu latach niezrozumiały staje się ich kontekst. Część politycznych przekazów o charakterze satyrycznym udało się ocalić dzięki rozmaitym zbiorom i antologiom, albo z tej tylko racji, że zostały odnotowane na łamach pism satyrycznych. Wiele przepadło na zawsze w mrokach niepamięci. Niektóre zachowały się dzięki pamiętnikom i wspomnieniom ${ }^{27}$.

26 P. Buchwald-Pelcowa, Satyra, [w:] Literatura polska. Przewodnik encyklopedyczny, t. II, Warszawa 1985, s. 338-339.

27 Wśród zbiorów takich wypada wspomnieć: Dowcip polityczny: Polska '93, Białystok 1993; Dowcip polityczny 1989-1992, Lublin 1992; Komuno wróć, Warszawa 1993; Na erewiańskiej fali, Warszawa 1990; Najnowszy dowcip polityczny, Lublin 1993; Nie chcem, ale muszem. 300 dowcipów o Lechu Watęsie i nie tylko, Łódź 1992; Nowy dowcip polityczny, Warszawa 1997 ; Zielone pająki, Warszawa 1993; 501 dowcipów politycznych Wałbrzych 1993; Anegdota prawdę co powie..., wybór i oprac. J. Mikołajczak, B. Paluszkiewicz, M. Frajtak, Poznań 1995; Antologia satyry polskiej 1944-1955, red. A. Marianowicz, Warszawa 1955; A. Binkot, P. Binkot, W. Cesarski, Małe vademecum Peerelu $z$ wycinków gazet podziemnych $w$ formie kalendarza robotniczego na rok 1990, wstęp S. Bratkowski, Warszawa 1990; Z. Bosacki, Pierwszy lepszy Sejm. Stenogramy nie-parlamentarne, Poznań 1993; Dowcip surowo wzbroniony. Antologia polskiego dowcipu politycznego, red. V. Syguła-Gregowicz, M. Waloch, Toruń 1990; Dowcip surowo wzbroniony. Antologia polskiego dowcipu politycznego, t. II, red. V. Syguła-Gregowicz, M. Waloch, Toruń 1991; Kawal polski, red. M. Radecka, Warszawa 1983; Satyra polska w walce o pokój (wstęp J. Szeląg), Warszawa 1950; Satyra prawdę mówi... 1928-1939, red. Z. Mitzner, L. Pasternak, Warszawa 1963; Żarty niepoświęcone (pozbierał i opowiedział ks. Jan Kracik), Kraków 1993; zob. także: J. Krzywda Pogorzelski, Pieśni $i$ wiersze satyryczne opozycji do rządów legionowo-sanacyjnych 1926-1939, 
Nie wdając się w problematykę historyczno-literacką, pomijając kuszące zagadnienia teoretycznoliterackie, pozostawiając na uboczu bliższą klasyfikację satyry, ciekawe kwestie odnoszące się do form wypowiedzi satyrycznych, należy zauważyć, że satyra polityczna - zarówno w przeszłości, jaki w chwili obecnej - narażała twórców utworów satyrycznych na odpowiedzialność, wiodąc ich jako oskarżonych w sprawach karnych lub pozwanych w postępowaniu cywilnym przed oblicze organu sprawiedliwości. Wielokrotnie osoby ugodzone ostrzem satyry pomijały drogę prawną, rozprawiając się z twórcami utworów przy użyciu siepaczy i płatnych zabójców. Musi dziwić fakt, że jak dotąd brak w literaturze dzieła, które w sposób pełny i całościowy prezentowałoby te zjawiska ${ }^{28}$.

Od starożytności po dzień dzisiejszy społeczeństwo gotowe jest przyznawać satyrykom, twórcom żartów, pamfletów, paszkwili, kalamburów i dowcipów prawo do wykpiwania rozmaitych stron życia społecznego ${ }^{29}$. W przeszłości z tej swoistej licencji korzystali błaźni ${ }^{30}$. Dowcip polityczny nie jest jedynie bronią, której przeciwko politykom używają członkowie społeczeń-

Detroit 1981; T. Szczerbakowski, O grach językowych w tekstach polskiego i rosyjskiego kabaretu lat osiemdziesiątych, Kraków 1994; J. Fedorowcz, Felietony i dialogi, Warszawa 1989; J. Pietrzak, Co jest grane panie Janku, Warszawa 1992, S. Latanowicz, Satyra i polemika prasowa z przed stu laty, Poznań 1931; M. Tobera, Wesołe gazetki. Prasa satyryczno-humorystyczna w Królestwie Polskim w latach 1905-1914, Warszawa-Łódź 1988; E. Skorupa, Lwowska satyra polityczna, Kraków 1992; W. Filler, Szczutek, Cyrulik Sewilski, Szpilki, Warszawa 1995; A. Garlicki, J. Kochanowski, Józef Piłsudski w karykaturze, Warszawa 1931; W. Husarski, Karykatura w Polsce, Warszawa 1926; H. Górska, E. Lipiński, Z dziejów karykatury polskiej, Warszawa 1977; A Zakrzewski, Prosto z Wiejskiej, Wrocław-Warszawa-Kraków 1990; Z dziejów cnoty. Szpilki 1935-1985, Warszawa 1985; J. Lenica, A. Marianowicz, J. Szeląg, Polska karykatura polityczna, Kraków 1951; M. Raczkowski, Historyjki obrazkowe, Kraków 2004; Kawały, czyli anegdoty polityczne z PRL i nie tylko, Warszawa 2005; L. Straszewicz, Śmiech w kajdanach. Kawaty warszawskie z czasów okupacji, Kraków 1946; E. Lipiński, J. Szeląg, Pożegnanie z Hitlerem, Warszawa 1946; M.R. Buczkowski, Warszawski dowcip w walce 1939-1944, Warszawa 1947; Proletariusze wszystkich krajów, przepraszam. Komuna w dowcipie, Warszawa 1991; Absurdy PRLu. Antologia, oprac. M. Rychlewski, Poznań 2006; M. Ogórek, Przewodnik po Polsce, Warszawa 1991; Diplomex. Noty i anegdoty polityczne, Warszawa 1977; S. Kobyliński, Jak dobrze mieć sąsiada, Warszawa 1974; idem, Domysty, Warszawa 1975; Nie tylko do śmiechu. Dowcipu z czasów Peerelu 1948-1989. Z wieloletniej kolekcji Bronisława Sałudy, wybrał oraz rysunkami opatrzył S. Kobyliński, Warszawa 1991. Znakomitą teoretyczną analizę języka polskiej satyry politycznej z początku lat dwudziestych przynosi mało znana, a świetnie udokumentowana praca Ireny Kamińskiej-Szmaj, Judzi, zohydza, ze czci oddziela. Język propagandy politycznej w prasie 1918-1923, Wrocław 1994.

${ }^{28}$ Kwestiom tym poświęcił uwagę J. Sobczak, Ramy prawne satyry politycznej, [w:] Fenomen radości, red. A. Grzegorczyk, J. Grad, P. Szkudlarek, Poznań 2007, s. 209-240; P. Wasilewski, Wolność prasowej wypowiedzi satyrycznej. Studium cywilistyczne na tle porównawczym, Warszawa 2012, passim; R. Tymiec, Satyra a ochrona czci w polskim prawie cywilnym, [w:] Wybrane zagadnienia prawa cywilnego, red. M. Warciński, K. Zaradkiewicz, Warszawa 2006, s. 185-192.

29 R. Quintero, A Companion to Satire, Blackwell Publishing, s. $1 \mathrm{nn}$.

30 B. Fabiani, Niziolki, łokietki, karlikowie: Z dziejów karłów nadwornych w Europie, Warszawa 1980, passim; M. Wilska, Błazen na dworze Jagiellonów, Warszawa 1998, passim; M. Słowiński, Błazen dzieje postaci i motywu, Warszawa 1993, passim; M. Sznajderman, Błazen. Maski metafory, Gdańsk 2000, passim. 
stwa. Ze środka tego korzystają chętnie sami politycy, gdy okazuje się, że jest to oręż bardziej skuteczna niż uczone teoretyczne wywody ${ }^{31}$.

Wypada wyraźnie zauważyć, że wszelka sztuka, w tym w szczególności wypowiedź artystyczna, a już zwłaszcza satyra może godzić w dobra chronione zarówno przez prawo karne, jak i cywilne. Może naruszać zarówno część zewnętrzną, jak i wewnętrzną, zniesławiać, znieważać, naruszać uczucia religijne, dobre imię. Zauważalna antynomia między społecznym przyzwoleniem nie tylko na krytykę działalności zawodowej, publicznej i twórczej, na formułowanie ujemnych ocen naukowych bądź artystycznych, a także na żarty, kpiny formułowane w formie przekazów satyrycznych bądź karykatur, a potrzebą ochrony takich dóbr jak cześć, godność, dobre imię i sława, doprowadziła do sformułowania kontratypu dozwolonej krytyki satyry i karykatury ${ }^{32}$. Kontratyp ten określony został w treści art. 41 ustawy z dnia 26 stycznia 1984 r., według której prawo prasowe ${ }^{33}$ stanowi istotne rozszerzenie kontratypu dozwolonej krytyki, przewidzianego w treści art. $213 \S 2$ k.k. ${ }^{34}$. Nie ulega także obiekcji zakres wolności wypowiedzi ${ }^{35}$, mocno obudowany zarówno orzecz-

31 E. Lanowski, Nie igra się z humorem Prasa polityczna i jej rysuneczki, [w:] Humor europejski, Lublin 1994, s. 27.

32 Jak wskazano w literaturze kontratypy to okoliczności wyłączające bezprawność czynu. Każdy kontratyp musi zaistnieć w sytuacji kolizji dóbr mających wartość społeczną, kiedy jedyną możliwą drogą rozwiązania tej kolizji jest poświęcenie jednego z dóbr, przy czym poświęcenie to jest społecznie opłacalne. Por. A. Zoll, „Pozaustawowe” okoliczności wyłączajace odpowiedzialność karna $w$ świetle konstytucyjnej zasady podziału władzy, [w:] W kręgu teorii i praktyki prawa karnego. Księga poświęcona pamięci prof. Andrzeja Wąska, red. L. Leszczyński, ed. E. Skrętowicz, Z. Hołda, Lublin 2005 s. 425-438. Jako podstawę wyłączenia bezprawności wskazuje się zwykle albo brak społecznej szkodliwości (W. Wolter, O kontratypach i braku społecznej szkodliwości czynu, „Państwo i Prawo”, 1963, nr 10, s. 502 nn.; A. Zoll, Stosunek kontratypów do ustawowej określoności czynu, „Państwo i Prawo”, 1975, nr 4, s. 83-92), albo przesłanki formalne (A. Krukowski, Materialna treść czynu a okoliczności wyłączajace bezprawność karną, „Nowe Prawo", 1971, nr 12, s. 1764), albo wreszcie inne czynniki np. w postaci niecelowości karania (M. Marek, J. Waszczyński, Obrona konieczna w prawie karnym na tle teorii i orzecznictwa Sądu Najwyższego, Warszawa 1979, ss. 176).

33 Dz. U. 1984, Nr 5, poz. 24 z późn. zm.

34 W kwestii kontratypu dozwolonej krytyki zob. komentarz J. Sobczaka do art. 213 k.k. [w:] Kodeks karny. Komentarz Online, red. R.A. Stefański, Wyd. Beck; także J. Sobczak, Kontratyp dozwolonej krytyki, [w:] Przestepstwa przeciwko czci i nietykalności cielesnej, IV Lubelskie Seminarium Karnistyczne, red. M. Mozgawa, w druku. Zob. także J. Sobczak, Prawo prasowe. Komentarz, Warszawa 2008, s. 856-866.

35 W przedmiocie tym zob. J. Sobczak, Wolność ekspresji artystycznej. Standardy europejskie i rzeczywistość polska, [w:] Rada Europy a przemiany demokratyczne $w$ państwach Europy Środkowej $i$ Wschodniej w latach 1989-2009, red. J. Jaskiernia, Torun 2010, s. 612-638. Zob. także J. Sobczak, Swoboda wypowiedzi w orzecznictwie Trybunatu Praw Człowieka w Strasburgu, cz. I, „Ius Novum”, 2007, nr 2-3, s. 5-38; cz. II, „Ius Novum”, 2007, nr 4, s. 5-43; idem, Wolność wypowiedzi prasowej a zniewaga, „Środkowoeuropejskie Studia Polityczne”, 2012, nr 1, s. 143-174; idem, Wolność środków społecznego przekazu czy wolność ekspresji o orzecznictwie Trybunaty w Strasburgu, [w:] Kulturowe instrumentalium wolności. Etyka i prawo, red. R. Paradowski, Poznań 2005, s. 163-208; idem, Prawo do prywatności a wolność słowa i druku, [w:] Wolności i prawa jednostki oraz ich gwarancje w praktyce, red. L. Wiśniewski, Warszawa 2006, s. 152-171. 
nictwem Europejskiego Trybunału Praw Człowieka, jak i rozważaniami doktryny $^{36}$, także na gruncie Karty Praw Podstawowych Unii Europejskiej ${ }^{37}$.

Problem wolności ekspresji artystycznej dotyka także kwestii odnoszących się do wolności sumienia i wyznania. Wolność ta ma postać osobista (jest wolnością osobistą) i jako taka ma charakter podmiotowy bezwzględny, czyli jest skuteczna wobec wszystkich. Zważywszy, iż statuują tę wolność zarówno akty prawa międzynarodowego publicznego systemu ONZ, jak i normy obu systemów praw europejskich (Rady Europy i Unii Europejskiej), a także normy polskiego prawa, wypada zaznaczyć, że we wszystkich tych systemach prawnych wolność sumienia i wyznania jest publicznym prawem podmiotowym. Tym samym zgodnie z tymi wszystkimi systemami prawnymi przysługuje ona każdemu. Z punktu widzenia Międzynarodowego Paktu Praw Obywatelskich i Politycznych „każdym” jest wszelka jednostka ludzka, ale nie tylko ${ }^{38}$. Warto zauważyć, że Pakty posługują się terminem „każda istota ludzka” (art.6), „każda osoba” (art.10), „każdy człowiek” (art. 12), „każdy” (art.16, 18, 19, 22) i wreszcie „każdy obywatel” (art.25). Znacznie bardziej precyzyjna w tym zakresie wydaje się Powszechna Deklaracja Praw Człowieka, która dość jednoznacznie operuje terminem „każdy człowiek” (art. 2, 3, 6, $8,10,11,13-15,17-29)^{39}$.

Należy już w tym miejscu podkreślić, iż treść regulacji zawartej w art.18 Powszechnej Deklaracji Praw Człowieka jest zbieżna, lecz nie identyczna, z tekstem art. 18 Międzynarodowego Paktu Praw Obywatelskich i Politycznych. Nie wchodząc na razie w obszar zakresu przedmiotowego trzeba podkreślić, że ujęcie zawarte w Powszechnej Deklaracji Praw Człowieka, posługującej się terminem „każdy człowiek”, wydaje się bardziej precyzyjne, ale jednocześnie węższe od określenia „każdy”, do którego ucieka się Między-

36 Por. w tym przedmiocie Konwencja o ochronie Praw Człowieka i Podstawowych Wolności, red. L. Garlicki, t. I, Warszawa 2010, s. 583-648; por. także I.C. Kamiński, Swoboda wypowiedzi w orzeczeniach Europejskiego Trybunału Prawa Człowieka w Strasburgu, wyd. III, Kraków 2006, s. 17 nn.; idem, Ograniczenia swobody wypowiedzi dopuszczalne w Europejskiej Konwencji Praw Człowieka. Analiza krytyczna, Warszawa 2010, passim; L. Gardocki, Europejskie standardy wolności wypowiedzi a polskie prawo karne, „Państwo i Prawo”, 1993, z. 3, s. 11 nn.; P. Hofmański, Komentarz do wybranych przepisów Europejskiej Konwencji o ochronie praw człowieka i podstawowych wolności, [w:] Standardy prawne Rady Europy. Tekst i komentarze. Prawo Karne, Warszawa 1997, s. 103. Polski tekst Konwencji został opublikowany w Dz. U. 1993 Nr 61, poz. 284; G. Roch-Bajorek, Władcy ust. Granice swobody wypowiedzi polityków $i$ wypowiedzi o politykach w świetle orzecznictwa Europejskiego Trybunatu Praw Człowieka w Strasburgu, Torun 2010, passim.

37 Zob. uwagi J. Sobczaka do art. 11 Karty Praw Podstawowych Unii Europejskiej [w:] Karta Praw Podstawowych Unii Europejskiej, red. A. Wróbel, Warszawa 2013, s. 421-477, ibidem: zestawienie literatury s. 421-425.

38 Międzynarodowy Pakt Praw Obywatelskich i Politycznych otwarty do podpisu w Nowym Jorku dnia 19 grudnia 1966 r. ratyfikowany przez Polskę 3 marca 1977 r. Dz. U. 1977 Nr 38, poz. 167.

39 Prawa Człowieka. Międzynarodowe zobowiązania Polski (Wybór dokumentów), red. A.D. Rotfeld, Warszawa 1989, s. 17-18. 
narodowy Pakt Praw Obywatelskich i Politycznych. Z treści sformułowania „każdy” można by domniemywać, że jest to prawo przysługujące nie tylko jednostkom ludzkim, lecz także osobom prawnym, tzn. kościołom, związkom wyznaniowym, stowarzyszeniom religijnym itd. Kwestia ta nie stała się jak dotąd przedmiotem analiz w literaturze prawniczej. Wypada jednak zauważyć, że nie tyle treść przywołanych przypisów, ile przyjęte zasady legislacyjne każą traktować wspomniane normy prawa międzynarodowego jako gwarantujące sformułowane w nich wolności poszczególnym jednostkom. Należy jednak pamiętać, że z treści art. 53 ust. 2 Konstytucji oraz z art. 10 ust. 1 Karty Podstawowych Praw Unii Europejskiej, a także z art. 9 ust. 1 Europejskiej Konwencji Praw Człowieka i Podstawowych Wolności wynika, że wspomniana wolność może być ,uzewnętrzniana indywidualnie lub z innymi”. W aspekcie podmiotowym zakres ochrony obejmuje nie tylko osoby fizyczne, ale i zbiorowości. A zatem ofiarą naruszenia wspomnianych przepisów i zawartych w ich treściach wolności mogą być nie tylko osoby fizyczne, lecz także wspólnoty religijne. W zasięgu prawa krajowego może budzić wątpliwości zdolność procesowa takich wspólnot, jeżeli nie należą one do grupy tych wspólnot (kościołów bądź związków wyznaniowych), które posiadają osobowość prawną w rozumieniu prawa cywilnego. W systemie prawnym Rady Europy podstawą roszczeń takich podmiotów będących wspólnotami wyznaniowymi może być art. 34 Europejskiej Konwencji o Ochronie Praw Człowieka i Podstawowych Wolności wymieniający wśród podmiotów uprawnionych do wnoszenia skargi organizacje pozarządowe lub grupy jednostek $^{40}$. Jednobrzmiące rozwiązania zostały przyjęte w Europejskiej Konwencji o Ochronie Praw Człowieka i Podstawowych Wolności (art. 9 ust.1) ${ }^{41}$ i Karty Podstawowych Praw Unii Europejskiej (art. 10 ust.1) ${ }^{42}$. Z ich treści wynika, że ustawodawca traktuje wolność myśli, sumienia i wyznania jako prawo osobiste przysługujące jednostce ludzkiej - człowiekowi. Podobnie art. 53 Konstytucji z 1997 r., zaliczając tę wolność do wolności i praw o charakterze osobistym, wiąże ją z treścią art. 25 statuującego jako zasadę ustrojową stosunek państwa (władz publicznych) do kościołów i związków wyznanio-

40 S. Hambura, M. Muszyński, Karta Praw Podstawowych z komentarzem, Bielsko-Biała 2001, s. 77. Jednak błędnie wskazano tu jako podstawę prawną, dyspozycję art. 25 Europejskiej Konwencji o Ochronie Praw Człowieka i Podstawowych Wolności, który dotyczy kancelarii i sekretarzy prawnych Trybunału Praw Człowieka w Strasburgu.

41 Konwencja o Ochronie Praw Człowieka i Podstawowych Wolności sporządzona w Rzymie 4 listopada 1950 r. zmieniona następnie Protokołami nr 3, 5 i 8 oraz uzupełniona Protokołem nr 2 ratyfikowana prze Polskę 15 grudnia 1992 Dz. U. 1993 Nr 61, poz. 284; uzup. Dz.U.1995, Nr 36, poz. 175 i 176; zm. Dz. U. 1995, Nr 36, poz. 177; 1998, Nr 147, poz. 962, uzup. Dz. U. 2001, Nr 23, poz. 266, 2003, Nr 42, poz. 364.

42 M.A. Nowicki (wprowadzenie i tłumaczenie), Karta Podstawowych Praw Unii Europejskiej, Zakamycze 2001, s. 29-30; S. Hambura, M. Muszyński, Karta Praw Podstawowych z komentarzem, s. 75-79. 
wych. W treści art. 25 Konstytucji formułuje nie jedną, a pięć zasad ustrojowych określających stosunek państwa (władz publicznych) do istniejących kościołów i innych związków wyznaniowych. W tym miejscu wypada jednak zauważyć, iż w literaturze podkreśla się, że stanowią one wyraz kompromisu „zaakceptowanego przez głównych aktorów prac konstytucyjnych” oraz że w tym ujęciu nie są one konfliktogenne ${ }^{43}$. Konstytucja 1997 r. przyjęła ,,technikę dyspersji materii wyznaniowej".

W przestępstwie obrazy uczuć religijnych, stypizowanym w art. 196 k.k., widzi się przepis wywodzący się z treści art. 172 k.k. z 1932 r., kryminalizującego bluźnienie Bogu. Obowiązujące ustawodawstwa państw zaborczych przed wejściem w życie k.k. z 1932 r. znały przestępstwa skierowane przeciwko religii i uczuciom religijnym. W myśl §122 lit. a austriackiej ustawy karnej z dnia 27 maja 1852 r. o zbrodniach, występkach i wykroczeniach, ,zbrodnię obrazy religii popełnia kto mową lub czynami w drukach lub rozszerzanych pismach Bogu bluźni" "44. Podobne rozwiązanie znalazło się w bardzo rozbudowanej treści art. 73 i 74 rosyjskiego kodeksu karnego z dnia 22 marca 1903 r.

Stosując k.k. ros. z 1903 r., Komplet Całej Izby Karnej Sądu Najwyższego postanowieniem z dnia 26 marca 1925 r. (II K 3/1925) wywiódł, że ,istotą przestępstw religijnych jest pogwałcenie wolności religijnej i obraza uczuć religijnych ludzi wierzących w sferze ich najgłębszych uczuć", podkreślając, iż ,wszelkie zamachy na religję mogą doprowadzić do reakcji ze strony ludu w formie niepokojów i zamieszek i podkopać podwaliny bytu państwowego". W dalszej części stwierdził, że ,,bluźnierstwo (blasphemia) dzieli się według k.k. na cztery grupy: a) bluźnierstwo w ścisłem znaczeniu (w rosyjskim tekście wozłożenje chuły przeciwko Bogu, we współistotnej Trójcy wysławianemu, przeciwko Matce Boskiej, Niecielesnym Mocom Niebieskim i Świętym Wybrańcom Bożym, b) sponiewieranie czynne lub zelżenie Sakramentów Świętych, Krzyża Świętego, Relikwij Świętych, Obrazów Świętych, oraz innych przedmiotów, uznawanych przez poszczególne kościoły chrześcijańskie za święte i wyliczonych w załączniku do art. 73 k.k. ros. z 1903 r., a także zelżenie Pisma Świętego, albo Kościoła i jego dogmatów, albo w ogóle wiary chrześcijańskiej, c) profanacja (w tekście rosyjskim koszczunstwo) polegająca na zelżeniu praktyk lub obrzędów kościoła chrześcijańskiego, sponiewieraniu czynem lub zelżeniu przedmiotów, poświęconych przez użycie przy nabożeń-

43 Ks. J. Krukowski, Konstytucyjny system relacji między państwem a kościolem katolickim oraz innymi kościołami i związkami wyznaniowymi, [w:] Ustrój konstytucyjny Rzeczypospolitej Polskiej, red. E. Mojak, t. X, Lublin 2000, s. 101.

44 Sąd Najwyższy Cesarstwa Austro-Węgier na gruncie tego przepisu uznawał, że znamiona tego przestępstwa wyczerpują wyrażenia bluźniercze i obelżywe wobec Jezusa Chrystusa. Podkreślono jednak, że dla wyczerpania znamion przestępstwa konieczne jest ustalenie zamiaru poniżenia Najwyższej Istoty. Zob. J. Rosenblatt, Ustawa karna o zbrodniach, występkach i przekroczeniach, cz. I, Kraków 1914, s. 197-188. 
stwie chrześcijańskiem, wyliczonych w dodatku do art. 74 k.k. ros. z 1903 r., i wreszcie nieprzystojne drwiny z przedmiotów świętych lub przedmiotów wiary, wymienionych w art. 73 k.k. ros. z 1903 r., i d) nieobyczajność i wybryki podczas nabożeństwa chrześcijańskiego lub w świątyni chrześcijańskiej. Pierwsze dwa z tych przestępstw przewidziane są w art. 73 k.k. ros. z 1903 r., trzecie w art. 74 k.k. ros. z 1903 r. i czwarte w art. 75 k.k. ros. z 1903 r. Przestępstwa religijne przeciwko wyznaniom niechrześcijańskim ścigane są z art. 76 i 77 k.k. ros. z 1903 r. Użyty w art. 73 k.k. ros. z 1903 r. wyraz zelżenie (ponoszenje) oznacza cięższą formę zniewagi, świadczącej nie tylko o braku szacunku, ale i pogardzie sprawcy dla przedmiotu znieważonego, nieprzystojne drwiny zaś - jest to okazanie nieposzanowania bez chęci znieważenia”. Dodał, że ,ze względu na okoliczności, wśród których przestępstwo z art. 73 k.k. ros. z 1903 r. lub 74 k.k. ros. z 1903 r., może być dokonane, ustawa przewiduje trzy wypadki: a) dokonanie przestępstwa podczas nabożeństwa lub w kościele (najcięższa forma), b) w kaplicy, w domu modlitwy, albo rozpowszechnianych $\mathrm{w}$ druku, piśmie lub wizerunku albo publicznie i c) przy świadkach w celu wywołania zgorszenia wśród obecnych. W tym więc ostatnim wypadku dla istoty przestępstwa ze strony podmiotowej niezbędny jest zły zamiar bezpośredni (dolus directus), w pozostałych zaś wypadkach dostateczne jest, by sprawca zdawał sobie sprawę, że działanie jego z treści swej stanowi zelżenie religji lub drwiny z niej (dolus eventualis), bluźnierstwo więc dokonane nie publicznie i bez zamiaru wywołania zgorszenia nie jest karalne, jak również nie jest karalna krytyka dogmatów i obrzędów kościoła bez zamiaru ich znieważenia”. Sąd Najwyższy wskazał, że jak ,wynika z tekstu art. 73 k.k. ros. z 1903 r., osobną grupę przestępstw stanowi sponiewieranie czynne lub zelżenie «Sakramentów Świętych, Krzyża Świętego, relikwij świętych i obrazów świętych», ponieważ jednak w załączniku do tego artykułu wśród przedmiotów, uznanych przez kościół katolicki za święte, pomieszczone są między innemi relikwie, krzyże i ewangelje, używane przy nabożeństwie" 45 .

W art. 172 k.k. z 1932r. stwierdzono: „Kto publicznie Bogu bluźni podlega karze więzienia do lat 5". Na tle tego przepisu Sąd Najwyższy w uzasadnieniu wyroku z dnia 27 lutego 1934 r. zauważył, że bluźnierstwo z art. 172

45 Wyrok Izby Drugiej Karnej Sądu Najwyższego w pełnym składzie z dnia 26 marca 1925 r., II K 3/1925, Zbiór Orzeczeń Sądu Najwyższego, Orzeczenia Izby Karnej rok 1925, Warszawa 1926, s. 228-229. W treści tego orzeczenia Sąd Najwyższy wskazał, że rosyjski kodeks karny z 1903 r. przyjął założenie, że istotą przestępstw religijnych jest pogwałcenie wolności religijnej i obraza uczuć religijnych osób wierzących. Zauważył, że przestępstwo to może popełnione być podczas nabożeństwa lub w świątyni, przez rozpowszechnianie druków, pism bądź wizerunków, przy świadkach w celu wywołania zgorszenia wśród obecnych. Stwierdził, że bluźnierstwo dokonane niepublicznie i bez zamiaru wywołania zgorszenia nie jest karalne, podobnie jak krytyka dogmatów i obrzędów kościoła bez zamiaru ich znieważenia. W wypadku bluźnierstwa działanie sprawcy świadczyć ma nie tylko o braku z jego strony szacunku dla przedmiotów wiary chrześcijańskiej, ale i o wykazaniu z jego strony pogardy. 
k.k. z 1932 r. jest działaniem przeciwko każdej religii stojącej na gruncie deistycznym $^{46}$. W uzasadnieniu wyroku z dnia 5 lipca 1938 r. wywiedziono, że ustawodawstwo polskie nie zabrania ani wywodów niezgodnych z panującą religią, ani nawet zaprzeczających istnieniu Boga, byle tylko owe wywody nie stanowiły bluźnierstwa, czyli uwłaczaniu Bogu, naruszeniu czci należnej Bogu w postaci obelg, szyderstw, urągania i innych zniewag. W dalszym ciągu zauważono, że zamieszczanie nawet w dziełach naukowych treści bluźnierczych stanowi przestępstwo ścigane $\mathrm{z}$ art. $172 \mathrm{k.k.}{ }^{47}$.

$\mathrm{Na}$ gruncie kodeksu karnego z 1932 r. J. Markiewicz podkreślał, że bluźnienie oznacza wypowiadanie sformułowań naruszających cześć należną Bogu, ujmowanego zarówno z punktu widzenia czystego deizmu, jako istoty najwyższej, jak i osobowo ${ }^{48}$. W judykaturze podkreślano, że do ustawowej istoty czynów z art. 172 i 173 k.k. z 1932 r. nie należy okoliczność, czy następstwem ich było czyjejś zgorszenie lub obraza uczuć religijnych, wystarcza sama możliwość tych skutków, objęta zamiarem bezpośrednim lub ewentualnym sprawcy (3 K. 2547/37) ${ }^{49}$.

Przepis art. $172 \mathrm{KK} \mathrm{z} 1932$ r. został uchylony przez dekret z 5 sierpnia 1949 r. o ochronie wolności sumienia i wyznania ${ }^{50}$. We wspomnianym dekrecie wprowadzono w art. 5 przestępstwo obrazy uczuć religijnych, w treści którego stwierdzono, że ,kto obraża uczucia religijne, znieważając publicznie przedmiot czci religijnej lub miejsce przeznaczone do wykonywania obrzędów religijnych, podlega karze więzienia do lat 5". Treść art. 5 powtórzył następnie art. 198 k.k. z 1969 r., z tym jednak, że dodano w jego tekście słowo ,publicznego", także miejsce przeznaczone do wykonywania obrzędów religijnych miało być publiczne, ponadto zaś doprecyzował pojecie uczuć religijnych, sformułowane w art. 5 dekretu o znamię ,innych osób”, łagodząc jednocześnie sankcję karną, gdyż sprawca przestępstwa z art. 198 k.k. z 1969 r. podlegać miał karze pozbawienia wolności do lat 2, ograniczenia wolności, albo grzywny. W toku dyskusji nad potrzebą zmiany k.k. z 1932 r., podnoszono, że uczucia religijne są sprawą prywatną i godzenie w nie powinno być ścigane z oskarżenia prywatnego. Postulowano także zawężenie „publicznego znieważenia” do kościołów i świątyń, co uniemożliwiłoby postawienie w stan oskarżenia osób, wypowiadających się o religii, dogmatach $\mathrm{w}$ restauracjach, w środkach komunikacji, na zebraniach ${ }^{51}$. Na tle treści art. 198 k.k. z 1969 r. wypracowano w doktrynie pewne standardy, wskazując,

46 Wyrok Sądu Najwyższego z dnia 27 lutego 1934 r., 2 K 42/34, OSP 1934, z. 2, poz. 23.

47 Wyrok Sądu Najwyższego z dnia 5 lipca 1938 r., 1 K 1895/37, OSNIK 1939, z. IV, poz. 81.

48 J. Markiewicz, Kodeks karny z komentarzem, Lwów 1938, s. 443.

49 Zb. Orz. 1938, z. X, poz. 250.

50 Dz. U. 1949, Nr 45, poz. 334.

51 B. Reiner, M. Staszewski, Zagadnienia wolności sumienia $i$ wyznania $w$ projekcie k.k., „Państwo i Prawo”, 1963, nr 8-9, s. 341. 
że uczucia religijne to stan wewnętrzny jednostki i jej stosunek do otoczenia obraza tych uczuć może zaś nastąpić zarówno przez wypowiedzenie znieważających słów, jak i rozpowszechnienie pisma lub druku, zawierającego takie słowa oraz niszczenie przedmiotu kultu religijnego. Wskazywano, że z treści danej religii wynika, co jest przedmiotem czci religijnej, podnosząc, że może to być krzyż, hostia, święty obraz, figura świętego, Pismo Święte $\mathrm{e}^{52}$, natomiast miejsce przeznaczone do publicznego wykonywania obrzędów religijnych to w pierwszym rzędzie świątynie różnych wyznań, kaplice i wszelkiego rodzaju budynki i pomieszczenia przeznaczone do tych celów przez kościoły i inne związki wyznaniowe. Do miejsc publicznego wykonywania obrzędów religijnych zaliczano także miejsca procesji i pielgrzymek, wykorzystywane za zgodą władz państwowych do publicznego wykonywania wspomnianych obrzędów ${ }^{53}$. Przyjmowano, że nie stanowi przestępstwa z art. 198 k.k. z 1969 r. krytyka dogmatów i założeń wiary. Za obrazę uczuć religijnych nie uznawano także usuwania emblematów religijnych z lokali instytucji państwowych lub społecznych, gdyż uznawano, że jest to zgodne z zasadą rozdziału Kościoła od Państwa, ponieważ usuwający je w takich sytuacjach nie działa w zamiarze wywołania obrazy czuć religijnych ${ }^{54}$. Podkreślano także, iż nie wyczerpuje znamion przestępstwa zniszczenie, uszkodzenie lub usunięcie przedmiotu czci religijnej, jeżeli działaniu nie towarzyszyła chęć znieważenia takiego przedmiotu, a przez to wywołania obrazy uczuć religijnych innych osób ${ }^{55}$. Wskazywano wówczas na fakt, że przestępstwo z art. 198 k.k. z 1969 r. jest czynem umyślnym, który może być popełniony w zamiarze bezpośrednim lub ewentualnym, gdyż wynika to z celowości działania sprawcy, na co wskazuje użycie w treści przepisu słów „znieważa” i „obraża" 56 . Dyspozycja art. 198 k.k. z 1969 r. została zastąpiona obecnie przez treść art. 196 k.k.

Wywodzenie obecnego art. 196 k.k. z treści art. 172 k.k. z 1932 r. wydaje się nieuzasadnione, gdyż obrażanie uczuć religijnych innych osób, publiczne znieważanie przedmiotów czci religijnej lub miejsc przeznaczonych do publicznego wykonywania obrzędów religijnych różni się i to w sposób istotny od „bluźnienia Bogu”. Boga nie można uznać za przedmiot czci religijnej, a raczej za podmiot owej czci. Natomiast wypowiedzi pod adresem Boga jakkolwiek nie byłby on pojmowany w określonej religii, mogą już obrażać uczucia religijne innych osób. Warto pamiętać, że na tle treści art. 172 k.k. z 1932 r. wyrażano w doktrynie pogląd, że wyczerpuje znamiona tego prze-

52 J. Bafia, K. Mioduski, M. Siewierski, Kodeks karny. Komentarz, t. II, Warszawa 1987, s. 208.

53 S. Lelental, System prawa karnego, t. IV, cz. 2, Wrocław 1989, s. 148

54 J. Bafia, K. Mioduski, M. Siewierski, op. cit., s. 208.

55 I. Andrejew, W. Świda, W. Wolter, Kodeks karny z komentarzem, Warszawa 1973, s. 198.

56 O. Chybiński, W. Gutenkunst, W. Świda, Prawo karne. Część szczególna, Warszawa 1971, s. 249 
stępstwa działanie przeciwko dogmatom każdej religii, co może powodować możliwość niepokoju ${ }^{57}$. Bluźnienie pojmowano jako wypowiedź naruszającą cześć należną Bogu, obejmujące obelżywą treść i formę, mogące polegać także na obelżywym geście. Sprawca winien przy tym działać ze świadomością znaczenia swojego postępowania dla uczuć religijnych innych osób, a więc możliwością wywołania oburzenia ${ }^{58}$. Dodać należy, że art. 173 k.k. z 1932 r. kryminalizował publiczne lżenie lub wyszydzanie uznanego prawnie wyznania lub związku religijnego, jego dogmatów, wierzeń lub obrzędów oraz znieważanie przedmiotu jego czci religijnej lub miejsc przeznaczonych do wykonywania obrzędów religijnych. Raczej właśnie w tym przepisie, a nie w art. 172 k.k. z 1932 r. należy upatrywać rozwiązania poprzedzającego treść art. 196 k.k. W projekcie kodeksu zwrócono uwagę, że czynności znieważenia przedmiotu czci religijnej lub miejsca przeznaczonego do wykonywania obrzędów religijnych nie trzeba dokonywać publicznie, aby wywołać u wyznawców danej religii tak samo przykre uczucie, jakie jest skutkiem publicznego lżenia lub wyszydzania wierzeń religijnych. Podniesiono przy tym, iż przykładowe wyliczenie czynności sprawczych utrudni stosowanie ustawy $^{59}$.

Na straży uczuć religijnych stoi dyspozycja art. 196 k.k. Rodzajowym przedmiotem ochrony art. 196 k.k. jest, wynikająca z konstytucyjnej zasady wolności sumienia i wyznania, wolność przekonań, w tym także uczuć obywateli w sprawach wiary i religii, będąca wyrazem tolerancji światopoglądowej państwa. Bezpośrednim przedmiotem ochrony są uczucia religijne innych osób, a więc ich stosunek do określonego wyznania religijnego. Ustawodawca chroni je przed działaniem sprawcy, obrażającego te uczucia i godzącego w nie bezpośrednio Jak stwierdził Trybunał Konstytucyjny w orzeczeniu z dnia 7 czerwca 1994 r. ${ }^{60}$, ,uczucia religijne ze względu na ich charakter podlegają szczególnej ochronie prawa. Bezpośrednio powiązane są bowiem z wolnością sumienia i wyznania, stanowiącą wartość konstytucyjną. Potwierdzają to także akty międzynarodowe, np. Deklaracja o eliminacji wszelkich form nietolerancji $\mathrm{i}$ dyskryminacji z powodu religii lub przekonań uchwalona przez Zgromadzenie Ogólne ONZ dnia 21 listopada 1981 r. Dlatego też działania naruszające uczucia religijne mogą być przedmiotem zakazu ustawowego także wówczas, gdyby były podejmowane za pomocą środków służących realizacji wolności słowa”. Pojęcie uczuć człowieka rozumiane jest w języku potocznym jako przeżycie natury psychicznej ,stan psychiczny, którego istotę stanowi ustosunkowanie się wewnętrzne do aktualnie działających

57 Projekt Kodeksu Karnego Komisji Kodyfikacyjnej Rzeczypospolitej Polskiej. Uzasadnienie części szczególnej, t. V, z. 4, Warszawa 1930, s. 98.

58 J. Makarewicz, Kodeks karny z komentarzem, Lwów 1932, s. 270.

59 Projekt Kodeksu Karnego..., s. 100.

60 Sygn. K 17/93, OTK 1994, cz. I, poz. 11, s. 90. 
bodźców, przeszłych lub przyszłych zdarzeń i wszystkich elementów otaczającego świata oraz własnego organizmu, emocje"61. Niekiedy definiuje się uczucie jako ,przeżycie natury społecznej, synteza wszystkich stanów emocjonalnych, stanowiąca główną motywację ludzkiego postępowania, zwykle przeciwstawiana logice i rozsądkowi" ${ }^{2}$. Uczucia są pewnymi przeżyciami emocjonalnymi, definiowanymi jako stan pobudzenia, zaburzenia równowagi, reakcja na bodziec. Występują w formie ujemnej jako cierpienie, przykrość, niezadowolenie oraz dodatniej - przyjemność, rozkosz, zadowolenia, czasem wyrażają się w reakcjach ekspresywnych radości, żalu, przykrości. Czynnikiem wywołującym emocje są bodźce o charakterze zmysłowym, uwarunkowane zmysłowością człowieka ${ }^{63}$.

Przestępstwo z art. 196 k.k. zasadza się w pierwszym rzędzie na obrazie uczuć religijnych poprzez publiczne znieważenie przedmiotu czci religijnej lub miejsca przeznaczonego do publicznego wykonywania obrzędów religijnych. W języku potocznym „obrazić” to: „wyrazić się o kimś, zachować się względem kogoś w sposób uchybiający jego godności; ubliżyć, znieważyć, naruszyć coś, wykroczyć przeciwko czemuś, np. obrazić uczucia religijne"64 - bądź uchybić czyjejś godności osobistej słowem lub czynem; znieważyć, naruszyć słowem lub czynem jakieś normy prawa lub wartości ${ }^{65}$. Obraza uczuć religijnych jest takim zachowaniem sprawcy, które w odczuciu konkretnej osoby lub grupy osób, a także w ocenie obiektywnej odbierane jest jako obelżywe i poniżające ich uczucia religijne ${ }^{66}$. Poniżający lub obelżywy charakter określonych zachowań należy oceniać obiektywnie, z „uwzględnieniem przekonań, panujących w kręgu kulturowym, z którego wywodzi się pokrzywdzony" ${ }^{67}$, przyjmując jako wzorzec przeciętnego członka danej grupy wyznaniowej ${ }^{68}$. Zachowanie to może przybrać formę wypowiedzi słownej, gestów, pisma, obrazów, przekazu filmowego. Może więc mieć postać werbalną (obelżywe słowa), pisemną (książka, artykuł, ulotka), plastyczną (rysunek, obraz, rzeźba, instalacja, satyra rysunkowa). Może przybrać także formę parodii, obrazu scenicznego bądź filmowego. Stwierdzenie, że określone zachowanie stanowi obrazę uczuć religijnych lub jest znieważeniem przedmiotów czci religijnej, powinno być - jak słusznie stwierdzono w doktrynie

61 Stownik języka polskiego, t. III, s. 578.

62 Uniwersalny słownik języka polskiego, t. IV, red. S. Dubisz, Warszawa 2003, s. 201.

63 Psychologia, red. T. Tomaszewski, Warszawa 1979, s. 566 i n.

64 Stownik języka polskiego, t. II, red. M. Szymczak, Warszawa 1988, s. 422.

65 Uniwersalny stownik języka polskiego, t. II, s. 1073.

66 J. Wojciechowska, [w:] A. Wąsek, R. Zawłocki, Kodeks karny. Część szczególna, wyd. 4, Warszawa 2010, s.899.

67 R. Paprzycki, Prawnokarna analiza zjawiska satanizmu w Polsce, Zakamycze 2002, s. 402.

68 A. Wąsek, Przestępstwa przeciwko przekonaniom religijnym ,, de lege lata” $i$,de lege frerenda”, „Państwo i Prawo”, 1995, nr 7, s. 36; W. Wróbel, [w:] Kodeks karny. Czesść szczególna, red. A. Zoll, t. II, wyd. 4, Warszawa 2013, s. 584-585. 
- dokonane z uwzględnieniem społecznych norm kulturowo-obyczajowych i powszechnie przyjętych kryteriów oceny ${ }^{69}$.

Obrazą uczuć religijnych jest znieważenie publiczne przedmiotu czci religijnej lub miejsca przeznaczonego do publicznego wykonywania obrzędów religijnych. Pod pojęciem ,przedmiotu czci religijnej” rozumie się zwykle przedmiot, który przez określoną wspólnotę religijną, kościół lub związek wyznaniowy uznany jest za przedmiot kultu, godny najwyższego szacunku, a niekiedy wręcz uwielbienia. Do przedmiotów tych zwykło zaliczać się: krzyż, hostię, obrazy i figury świętych, naczynia liturgiczne, szaty pontyfikalne, różaniec, czasami wskazuje się, że przedmiotami czci religijnej będą także „słowa mające charakter sprawowania sakramentów, imiona świętych i rytuały" ${ }^{\prime 70}$. Dyskusyjne w doktrynie jest czy przedmiotem czci religijnej jest Bóg. Według J. Wojciechowskiego, jest on podmiotem kultu, a więc nie może być przedmiotem. W ten sposób zachodzi, zdaniem tego autora, luka w prawie, gdyż niektóre czyny, obrażające uczucia religijne określonych osób mogą w ten sposób znaleźć się poza zakresem odpowiedzialności, choć ciężar gatunkowy takiej obrazy może być większy od zniewagi przedmiotu czy miejsca kultu $^{71}$. Odmiennie W. Wróbel, stwierdzający, że przedmiotem czci religijnej może być sam Bóg, jego wizerunek, postacie świętych czy Matki Boskiej ${ }^{72}$. Jeszcze inaczej widzi tę kwestię A. Wąsek, podkreślając, że przedmiotom, o których mowa w art. 196 k.k., nie musi być oddawana cześć religijna, gdyż są to przedmioty ściśle związane $\mathrm{z}$ oddawaniem czci religijnej, przedmioty przez które oddawana jest cześć religijna ${ }^{73}$. Zdaniem L. Gardockiego, działanie sprawcy polegać może na znieważaniu przedmiotu czci religijnej w sensie przedmiotu materialnego, np. figury przedstawiającej uosobienie bóstwa, obrazu, przedmiotu liturgicznego, a także ,przedmiotu w szerszym sensie obiektu kultu, np. znieważenie Mahometa, Buddy lub Jezusa"74. Podkreślić jednak należy, że Mahomet i Budda byli ludźmi, natomiast Jezus - człowiekiem, który był Bogiem, jedną z osób Trójcy Świętej.

Według M. Makarskiej, poza ustawowymi znamionami przestępstwa z art. 196 KK znajdują się wypowiedzi i zachowania wyrażające negatywny stosunek do przedmiotu czci religijnej lub wykorzystujące ten przedmiot jako element kreacji artystycznej, o ile ze względu na formę nie zawierają

${ }^{69}$ Wyrok SN z 17 lutego 1993 r., sygn. II KRN 24/92, „Wokanda”, 1993, nr 10, s. 8.

${ }^{70}$ J. Wojciechowska, [w:] A. Wąsek, R. Zawłocki, op. cit., s. 899.

71 J. Wojciechowski, Kodeks karny. Komentarz..., s. 340; podobnie J. Warylewski, Pasja czy obraza uczuć religijnych? Spór wokót art. 196 kodeksu karnego, [w:] W kręgu teorii i praktyki prawa karnego... s. 376; M. Filar, Przestępstwa przeciwko wolności, „Nowa Kodyfikacja Karna. Kodek Karny. Krótkie Komentarze”, Warszawa 1998, z. 18, s. 104.

72 W. Wróbel, [w:] Kodeks karny..., s. 586.

${ }^{73}$ A. Wąsek, Przestępstwa przeciwko..., s. 33.

${ }^{74}$ L. Gardocki, Prawo karne..., s. 258. 
elementów poniżających lub obelżywych ${ }^{75}$. Za znieważające przedmiot czci religijnej wypada uznać takie wypowiedzi, zachowania lub kreacje, które oceniane obiektywnie przez pryzmat obowiązujących w danej społeczności norm kulturowych, obrażają uczucia religijne innych osób ${ }^{76}$. Inaczej sprawę widzi J. Warylewski, wskazujący, że kryterium powinny być oceny osób wykształconych, znających się na sztuce ${ }^{77}$. Forma artystyczna lub cel naukowy działania mającego charakter znieważający nie powodują same z siebie wyłączenia odpowiedzialności karnej za obrazę uczuć religijnych bądź znieważenie publiczne przedmiotu czci religijnej. Cel kreacji artystycznej może zakładać, iż w sposób konieczny dojdzie do znieważenia przedmiotu czci religijnej lub miejsca przeznaczonego do publicznego wykonywania obrzędów religijnych. W literaturze podkreśla się, że dzieła artystyczne powinny być analizowane ze szczególną ostrożnością, aby nie ograniczać przy użyciu prawa karnego twórczej ekspresji, o ile nie przekracza ona ewidentnie dopuszczalnych granic ${ }^{78}$.

W doktrynie prezentowany jest pogląd, że nie ma charakteru znieważenia przedmiotu czci religijnej wypowiedź lub zachowanie wyrażające negatywny stosunek do przedmiotu czci religijnej lub wykorzystujący ten przedmiot jako element kreacji artystycznej. Zastrzega się zwykle jednak, że forma i treść takiego przekazu nie powinna zawierać elementów poniżających lub obelżywych. Musi być przy tym zachowana zasada proporcji dóbr i spełniony wymóg subsydiarności oraz specyficzny, artystyczny cel działania sprawcy ${ }^{79}$. Podzielając ten pogląd Sąd Najwyższy, w uchwale z dnia 29 października 2012 r. stwierdził, że przestępstwo określone w art. 196 k.k. popełnia ten, kto w swoim zamiarem bezpośrednim lub ewentualnym obejmuje wszystkie znamiona tego występku. Jednocześnie wywiódł, że charakter danej wypowiedzi bądź kreacji artystycznej powinien być oceniany obiektywnie w odwołaniu do obowiązujących w danej społeczności norm kulturowych. Dodał jednak, przywołując stanowisko W. Wróbla, że ,artystyczny lub naukowy cel działania sprawcy nie jest wystarczający do wykluczenia znieważającego charakteru tych działań ze względu na ich formę" $"$.

75 M. Makarska, Przestępstwa przeciwko wolności sumienia $i$ wyznania $w$ kodeksie karnym z 1997 roku, Lublin 2005, s. 177.

76 R. Paprzycki, Prawnokarna analiza zjawiska..., s. $45 \mathrm{nn}$.

77 J. Warylewski, Pasja czy obraza uczuć religijnych? Spór wokół art. 196 kodeksu karnego..., S. 374 .

78 T. Jasudowicz, Bluźnierstwo a kultura europejska: „pojedynek” między wolnościa ekspresji a wolnościa religii, „Studia Europejskie”, t. II, Warszawa 1998, s. 37; R. Paprzycki, Graj szatanie, „Rzeczpospolita” z 21 września 2000 r.

79 B. Budyn-Kulik, M. Kulik, Wolność działalności artystycznej jako okoliczność wyłaczajaca odpowiedzialność karna, [w:] Prawnokarne aspekty wolności, red. M. Mozgawa, Kraków 2006, s. $245 \mathrm{nn}$.

${ }^{80}$ Uchwała Sądu Najwyższego z dnia 29 października 2012 r., I KZP 12/12, OSNKW 2012, z. 11, poz. 112; zob. także W. Wróbel, [w:] Kodeks karny. Część szczególna..., s. 661. 
Podzielając te rozważania, należy zgodzić się także z wywodami zawartymi w uzasadnieniu wspomnianej uchwały co do tego, że zwrot „znieważać” w tradycji polskiego języka ogólnego odnoszony jest do rzeczy lub miejsca, natomiast termin „obrażać” do uczuć, przy czym obu tych zwrotów można użyć w stosunku do osoby fizycznej, którą można zarówno obrazić, jak i znieważyć. Zgodzić się także należy z zawartym tam stwierdzeniem, iż użyty w treści art. 196 k.k. czasownik „obraża” oraz imiesłów czynny „znieważając" wskazuje na to, że zachowanie sprawcy ma charakter intencjonalny i jest wyrazem umyślności zachowania, któremu towarzyszy zamiar mogący mieć postać zarówno chcenia, jak i godzenia się ${ }^{81}$. Oczywiście godne podkreślenia jest to, że sprawca dopuszczając się przestępstwa z zamiarem ewentualnym w zakresie skutków znieważenia umyślnością musi obejmować także znamię publicznego charakteru znieważenia ${ }^{82}$.

Ekspresja artystyczna: obrazy, rzeźby, instalacje, filmy, fotografie, scenografie sztuk teatralnych, a także karykatury wywołują, wywoływały w przeszłości i chyba zawsze wywoływać będą rozmaite kontrowersje wśród odbiorców. W gruncie rzeczy jest to immanentnie związane z samym procesem tworzenia, w którym tkwi chęć pewnej prowokacji ze strony artystów. Zjawisko to znane było już w starożytności, w dobie średniowiecza, odrodzenia i w późniejszych epokach. Wolność sztuki, twórczości artystycznej, satyry ${ }^{83}$.

Wątpliwości budzić musi natomiast istnienie kontratypu sztuki jako okoliczności wyłączającej bezprawność przekazu ${ }^{84}$. Kontratyp ten byłby kontratypem pozaustawowym. Należy zauważyć, że takowe kontratypy maja opis teoretyczny określający ich warunki i bywają rozważane w orzecznictwie Sądu Najwyższego. Pozwala to najczęściej na określenie w praktyce orzeczniczej opisu kontratypu. W doktrynie wskazuje się, że takowe kontratypy należą do nieskodyfikowanych, gdyż albo wynikają ze zwyczaju albo formułowane są przez naukę prawa i respektowane przez praktykę ${ }^{85}$.

Kontratyp sztuki, gdyby uznać jego istnienie, byłby, jak zauważa T. Gardocka, kontratypem pozaustawowym odnoszącym się do sytuacji, w których

81 Wspomniana uchwała Sądu Najwyższego z dnia 29 października 2012 r.; odmiennie, aczkolwiek niesłusznie, J. Sobczak, [w:] Kodeks karny. Komentarz, red. R. Stefański, Warszawa 2015, s. 123 oraz J. Wojciechowska, [w:] A. Wąsek, Kodeks karny. Komentarz, t. 1, Warszawa 2010, s. 301 .

82 W. Wróbel, [w:] Kodeks karny. Część szczególna..., s. 662-663.

83 Zob. J. Sobczak, Czy istnieje kontratyp sztuki? Regulacje europejskie a rozwiazania polskiego systemu prawnego, [w:] Uniwersalny i regionalny wymiar ochrony praw człowieka. Nowe wyzwania - nowe rozwiazania, red. J. Jaskiernia, t. 3, Warszawa 2014, s. 360-370.

${ }^{84}$ Wypada zauważyć, że w wyroku w sprawie III KK 274/14 Sąd Najwyższy rozważając istnienie w prawie polskim pozaustawowego kontratypu sztuki nie przesądził jednoznacznie czy oskarżony w tej sprawie mógł powołać się na kontratyp sztuki, gdyż - jak podkreślił - nie wyczerpał on znamion przestępstwa z art. 196. OSNKW 2015, z. 9, poz. 72.

85 Zob. M. Cieślak, Polskie prawo karne zarys systemowego ujęcia, Warszawa 1994, s. 218. 
sztuka wiąże się z popełnieniem czynu zabronionego ${ }^{86}$. Zgodzić się także należy z poglądem tej autorki, że kontratyp sztuki - gdyby przyjąć jego istnienie - byłby najbardziej zbliżony do ustawowego kontratypu stanu wyżej konieczności, uregulowanego w art. 26 k.k.

W niemieckiej i angloamerykańskiej doktrynie prawniczej sformułowano pogląd, że przekaz, mający charakter artystyczny, wyłącza odpowiedzialność jego twórcy za treść przekazu. U podstaw tego rozwiązania w literaturze amerykańskiej legło przekonanie, że cenność wypowiedzi artystycznej jest tak wielka, że należy przyznać jej pierwszeństwo przed innymi dobrami, chociażby takimi jak godność czy cześć, z którymi może wchodzić w konflikt ${ }^{87}$. Już wcześniej w nauce angloamerykańskiej podkreślono, że przekazy wizualne różnią się w istocie od werbalnych i formułowanych w formie pisemnej, przy czym konstatuje się, iż dziełem artystycznym jest każdy wytwór kultury stworzony w celu artystycznym. Podkreśla się przy tym, iż twórczość w formie obrazów nie powinna i nie może być poddawana identycznym restrykcjom, jak formułowana w języku, werbalizowana i zapisywana ${ }^{88}$. Z przekonania o wolności ekspresji artystycznej oraz o potrzebie zapewnienia wolności dostępu do dóbr kultury wywodzi się także w nauce niemieckiej tezę o potrzebie wyłączenia bezprawności naruszeń innych wolności i praw treściami utworów. Zauważa się jednak, że „kontratyp sztuki nie usprawiedliwia naruszenia każdego dobra chronionego prawem"89. Stanowisko takie razi woluntaryzmem i w gruncie rzeczy sprowadza się do tego, iż ocena naruszenia nadal spoczywać będzie w rękach organu sprawiedliwości, który powinien jedynie brać pod uwagę fakt, iż do naruszenia dóbr chronionych doszło za pośrednictwem dzieła sztuki. Zważywszy, że nie ma jednej powszechnie akceptowanej definicji sztuki, musi na tym tle powstawać musi szereg wątpliwości i kontrowersji wraz z potrzebą ewentualnego powoływania biegłych z odpowiednich dziedzin nauki ${ }^{90}$. Zauważyć przy tym wypada, że zasadność uznania twórczości artystycznej (sztuki) za okoliczność wyłączającą bezprawność czynu jest kwestionowana przez innych autorów w doktrynie niemieckiej ${ }^{91}$. Twierdzi się przy tym, że uznanie twórczości artystycznej za okoliczność wyłączającą bezprawność czynu godziłoby w spójność systemu prawnego, pozwalało na

86 T. Gardocka, Czy w polskim prawie karnym potrzebny jest kontratyp sztuki ?, „Palestra”, 2015, z 1-2, s. 24.

${ }^{87}$ E.J. Eberle, Arts Speech, http://lsr.nellco.org/cgi/viewcontent.cgi?article=1010\&context=rwu_fp

88 Por. A. Adler, What's left? Hate Speech, Pornography and the Problem for Artistic Expression, „California Law Review”, 1996, t. 8, nr 6, s. 1499.

89 Zob. M. Bächli, Das Recht am eigenen Bild, Basel-Genf-München 2002, s. 111.

90 Zob. M. M. Bieczyński, Pojęcie sztuki w niemieckiej literaturze prawniczej i orzecznictwie Niemieckiego Sądu Konstytucyjnego, Opole 2012, s. 17-72.

91 Zob. K. Schmoller, Strafrecht und die Freiheit der Kunst. Die Suche nach einer Grenze, [w:] Art goes Law, Dialoge zum Wechselspiel zwischen Kunst und Recht, red. D. Pauger, BöhlauWien 2005, s. 203-208. 
popełnianie czynów sprzecznych z prawem, ubierając je w szaty działalności twórczej artystycznej, wreszcie przyznawałoby priorytet sztuce nad innymi chronionymi prawem dobrami.

W nauce polskiej na kontratyp sztuki zwracał uwagę m.in. M. Filar ${ }^{92}$. Potrzebę skonstruowania pozaustawowego kontratypu sztuki postulowali J.J. Nalewajko i R. Kubiak, wskazując, że punktem wyjścia winno być zdefiniowanie dzieła artystycznego, sztuki, i proponując, aby przesłankami do takiej definicji i jednocześnie oceny poszczególnych przejawów ekspresji był: cel artystyczny, „zdrowy i zbawienny” efekt ogólny dzieła, szczerość inspiracji, dobra reputacja autora oraz porównanie z innymi dziełami znajdującymi się w swobodnym obiegu ${ }^{93}$. Koncepcja ta razi niedookreślonością przesłanek. Jak bowiem rozumieć „,szczerość inspiracji”, „,dobrą reputację” i na czym polegać ma ,porównanie z innymi dziełami”? Z jakich przesłanek będzie wynikał cel artystyczny, czy wystarczy tylko oświadczenie twórcy, czy konieczne będą inne warunki i wymogi? W gruncie rzeczy cała koncepcja zdaje się zasadzać na pojęciu dzieła artystycznego jako nowej kategorii prawnej. Dzieło takie winno odpowiadać zrelatywizowanym wymogom estetycznym, porównywalnym do abstrakcyjnego wzorca uznanego przez szerszy krąg odbiorców, zaspakajające istotne potrzeby w zakresie kultury i mające niepowtarzalny indywidualny charakter. W koncepcji tej autorzy nawiązują nie wprost do standardów uniwersalnych, które winny mieć w myśl poglądów doktryny zastosowanie w sytuacji, gdy określone zachowanie może obrażać uczucia religijne. L. Gardocki w takiej sytuacji proponuje odwołanie do przeważających ocen społecznych ${ }^{94}$. R. Paprzycki odwołuje się w takiej sytuacji do ,przekonań panujących w kręgu kulturowym, z którego wywodzi się pokrzywdzony" "95. W doktrynie niemieckiej zauważa się, że dzieło nie jest niemoralne, gdy wprawdzie uraża przeciętne uczucie wstydu i moralności ogółu, lecz nie gorszy człowieka o otwartym umyśle artystycznym, starającego się zrozumieć sztukę ${ }^{96}$.

W gruncie rzeczy tego typu wymogi spełniać mogą zawsze jedynie dzieła eklektyczne. Truizmem będzie przypominanie, iż artyści wyprzedzają zwykle swoją epokę i gusty estetyczne odbiorców. Przypomnieć należy chociażby, że dzieła impresjonistów były odrzucane przez współczesnych im odbiorców. Pomysł J.J. Nalewajki i R. Kubiaka, że efekt działań twórcy stanie się sztuką (dziełem artystycznym), jeśli zostanie uznany przez odpowiedni autorytet,

92 M. Filar, Sztuka a zagadnienie pornografii, „Nowe Prawo”, 1978, nr 10, s. 1432 i n.; idem, Pornografia. Studium z dziedziny polityki kryminalnej, Toruń 1977, s. 142-148.

93 Zob. J.J. Nalewajko, R. Kubiak, Sztuka jako okoliczność wyłączająca bezprawność?, „Palestra", 2000, nr 9-10, s. 31-43.

94 Zob. L. Gardocki, Prawo karne, wyd. 17, Warszawa 2011, s. 264.

95 R. Paprzycki, Graj szatanie, „Rzeczpospolita” z 21 września 2000 r.

96 H. Welzel, Das Deutsche Strafrecht. Eine systematische Darstellung, Berlin 1969, s. 447. 
w niebezpieczny sposób odbiera możliwość oceny zdarzeń wymiarowi sprawiedliwości. Trudno zarówno dziś, jak i w przeszłości znaleźć w jakiejś dziedzinie twórczości artystycznej autorytety niekwestionowane i niepodważalne. Jasną jest rzeczą, że dokonując ustaleń faktycznych każdorazowo sąd może, a czasem nawet powinien, zasięgać opinii biegłych, ale to nie biegli decydują o ocenie materiału dowodowego, lecz sąd, dla którego opinia biegłych jest tylko jednym z licznych dowodów. „Autorytet”, o jakim piszą J.J. Nalewajko i R. Kubiak, stałby ponad sądem i mógłby formułować opinie całkowicie arbitralne, niepodważalne i niekontrolowane.

Na innym stanowisku w odniesieniu do kontratypu dzieł sztuki stoi J. Warylewski, krytykujący zresztą poglądy J.J. Nalewajki i R. Kubiaka ${ }^{97}$. Według J. Warylewskiego w przypadku kontratypu sztuki istnieje modelowa sytuacja kolizji co najmniej dwóch dóbr chronionych przez prawo karne. Opowiadając się za istnieniem kontratypu sztuki, autor ten skonstatował, że winien być on identyfikowany przez zespół znamion, wśród których wymienił to, iż sprawcą czynu, a więc twórcą dzieła, może być jedynie artysta, a efektem jego działania dzieło o charakterze artystycznym - niekoniecznie utwór w rozumieniu art. 1 ustawy o prawie autorskim i prawach pokrewnych. Koniecznym przy tym jego zdaniem jest to, aby artystą kierowała chęć osiągnięcia artystycznego celu. Wskazywał, że konieczne jest dla oceny konkretnego zachowania zbadanie tego, czy sprawca - artysta - brał udział w instytucjonalizowanych wystawach, festiwalach i przeglądach twórczości, warsztatach artystycznych, sprawdzenie jego poziomu wykształcenia profesjonalnego np. ukończenia studiów plastycznych i dotychczasowego dorobku wystawienniczego. Zaproponowane kryteria także są nie do końca jasne. Przecież wielu uznanych artystów nigdy nie skończyło żadnych studiów, wielu przyznawało się, że swoje dzieła stworzyli przypadkiem, a nie motywowani chęcią osiągnięcia artystycznego celu, niektórzy nie brali udziału w żadnych wystawach lub co gorsza ich dzieła były odrzucane przy organizowaniu tego rodzaju imprez, a przecież dzisiaj nikt nie odmawia im miana artysty, a wręcz przeciwnie uznawani są za wybitnych artystów.

Z poglądami J. Warylewskiego korespondują w części wywody M. Budyn-Kulik i M. Kulik, według których ,działalność artystyczna tylko wtedy wypełnia znamiona czynu zabronionego, gdy zamiarem twórcy jest nie tylko osiągnięcie celu artystycznego, lecz również popełnienie czynu zabronionego"98.

97 Zob. J. Warylewski, Przestępstwa przeciwko wolności seksualnej i obyczajowości. Rozdziat XXV kodeksu karnego. Komentarz, Warszawa 2001, s. 206. J. Warylewski zwraca uwagę, że cel artystyczny, czyli działanie motywowane chęcią przekazania idei, uczuć lub przeżyć twórcy, artystyczny charakter dzieła, profesjonalizm i mistrzostwo muszą być uwzględniane przy wyznaczaniu kontratypizacji, ale nie zawsze są możliwe do osiągnięcia, zwłaszcza przez debiutantów. J. Warylewski, Pasja czy obraza uczuć religijnych., Spór wokół art. 196 kodeksu karnego..., s. 367-381.

98 Zob. M. Budyn-Kulik, M. Kulik, op. cit., s. 234-246. 
Autorzy ci akcentują, iż wyłączenie odpowiedzialności przez kontratyp sztuki winno być społecznie opłacalne, podnosząc że istnieje katalog dóbr, w stosunku do których bez żadnych wątpliwości nie może zostać wyłączona w żadnym układzie faktycznym bezprawność czynu stanowiącego przejaw działalności artystycznej. Kontratyp sztuki ich zdaniem ma charakter subsydiarny, co oznacza, że dla jego przyjęcia konieczne jest wykazanie, że zamierzonego przez twórcę celu artystycznego nie można było osiągnąć w inny sposób niż przez poświęcenie dobra innej osoby. Artysta nie może więc sobie uzurpować prawa do publicznego piętnowania postaw niegodnych $\mathrm{z}$ jego poglądami w sposób obraźliwy bądź przykry dla innych. Podnoszą także, że przekonania religijne i moralne stoją wyżej niż odczucia estetyczne.

Jeszcze inną koncepcję zaproponował J. Piskorski, dystansujący się zarówno od rozwiązań lansowanych przez J. J. Nalewajkę i R. Kubiaka, jak i od postulatów M. Budyn- Kulik i M. Kulika. Podnosi on, że kontratyp sztuki ma charakter pozaustawowy, nie znajdując przekonywującego oparcia w przepisach Konstytucji, gwarantującej wolność twórczości artystycznej. Zwraca przy tym uwagę, że wolność ta podlega ograniczeniom wynikającym z treści art. 31 ust. 3 Konstytucji. Podkreśla ponadto, że istnieje obszerny katalog dóbr i wartości, które mają pierwszeństwo przed wolnością twórczości artystycznej, wśród nich są życie, zdrowie i bezpieczeństwo państwa. Wskazuje wreszcie, że sformułowanie kontratypu sztuki może być ,głęboko sprzeczne z intencjami artystów", którzy często świadomie działają na granicy prawa, pragnąc w ten sposób zwrócić uwagę na przedstawiany w dziele problem ${ }^{99}$.

Zauważyć jednak należy, że istotą przestępstwa z art. 196 k.k. jest to, że pokrzywdzony, którego uczucia zostały obrażone przez publiczne znieważenie przedmiotu czci religijnej winien niejako bezpośrednio doznać tej obrazy. Obraza uczuć religijnych nie może sprowadzać się do tego, że pokrzywdzony niejako „poszukuje” zdarzeń, sytuacji, które mogłyby jego uczucia obrażać, stojąc na stanowisku, że obowiązkiem każdego współobywatela bądź współmieszkańca jest takie zachowanie, które nie będzie z jednej strony prowadziło do publicznego znieważenia przedmiotu czci religijnej i w konsekwencji obrażała uczuć religijnych. Prowadzi to do wniosku, że obrażony w uczuciach religijnych może być ten, kto był obserwatorem zniewagi przedmiotu czci religijnej, a nie ten, który dowiedział się o takim znieważeniu, nawet publicznym, po jakimś czasie lub wręcz poszukiwał informacji o takim znieważeniu.

Następną płaszczyzną, której dotyczy wolność presji, jest przekaz pornograficzny.

Wytyczenie granicy miedzy pornografią a sztuką nie jest łatwe do określenia, a być może nawet niemożliwe. Zmienia się bowiem zarówno wrażliwość

99 J. Piskorski, Kontratyp sztuki?, [w:] Wokół problematyki prawnej zabytków i dzieł sztuki, red. W. Szafrański, Poznań 2007, s. 165-172. 
twórcy, jak i odbiorców. Zmieniają się nastawienia do przedstawienia nagiego ciała, stosunku seksualnego, nastawienia do miłości, małżeństwa, do erotyzmu i seksualizmu rozumianych jako zjawiska społeczne. Pomyślane jako „obsceniczne” rysunki z Pompei, zachowane dzięki wybuchowi wulkanu, uchodzą dziś za dzieła sztuki, prezentowane w poważnych wydawnictwach, podobnie jak malowane greckie wazy i amfory, wystawiane w szacownych muzeach, prezentowane tak jednak, aby ukryć obrazy stosunków homoseksualnych i członka męskiego we wzwodzie ${ }^{100}$. Skandalizujące niegdyś opinię publiczną obrazy Édouarda Maneta z lat sześćdziesiątych XIX w., np. Śniadania na trawie (1963) czy Olimpia (1865), podobnie jak pełne erotyzmu rzeźby Auguste'a Rodina uznawane są przez dzisiejszych odbiorców za pozbawione jakichkolwiek związków z sferą erotyczną i odbierane jako szacowne, choć nieco nudne obiekty muzealne. Warto jednak zauważyć, że historycy sztuki nawet w słynnej rzeźbie Gian Lorenza Berniniego Ekstaza Świętej Teresy dopatrują się przedstawienia orgazmu ${ }^{101}$. Oddzielenie sztuki od erotyzmu jest więc niezwykle trudne ${ }^{102}$. Niemniej warto zauważyć, iż człowiek poszukuje treści erotycznych, obscenicznych, a nawet pornograficznych. Powody tych poszukiwań są dość różnie interpretowane, zarówno na gruncie seksuologii, psychologii, jak i historii sztuki. Nie neguje się jednak faktu, że ,zapotrzebowanie" na tego rodzaju przesłania istnieje ${ }^{103}$.

Zauważa się, że popularność pornografii rośnie, a jej znaczenie w kulturze jest coraz większe. Dostarcza ona wzorów dla życia intymnego, przez co ono staje się wprost pornograficzne ${ }^{104}$. Wraz z rozwojem środków przekazu, zmianami technologicznymi, pornografia przestała być obrazem olejnym, akwarelą, grafiką, rysunkiem, ewentualnie przesyconą erotyzmem rzeźbą figuralną, stając się fotografią, obiektem przekazu filmowego, czy często bardzo osobistego przesłania internetowego. L. Williams stwierdza, że dyskusja na temat ekstremalnych i brutalnych treści zawartych w pornografii napędzana jest przez dwie obawy. Pierwsza z nich koncentruje się na tym, że osoby, których ciała zostały wykorzystane do nakręcenia obscenicznych, sprośnych scen, mogły zostać skrzywdzone. Druga z tych obaw sprowadza się do twierdzenia, że skrzywdzeni zostają odbiorcy ${ }^{105}$. Zauważa się także, że wraz z rewolucją

100 W kwestii estetyki przedstawień zob. chociażby U. Eco, Historia piękna, Poznań 2005, s. $154-175$.

101 E. Lucie-Smith, Erotism in Western Art, London 1972, s. 82; por. także K. Piwocki, Dzieje sztuki $w$ zarysie, t. 2, Warszawa 1977, s. 184. Zob. także P. Krakowski, Z rozważań nad sztuka erotyczną, [w:] Sztuka a erotyka. Materiały z sesji Stowarzyszenia Historyków Sztuki Lódź, listopad 1994, red. T. Hrankowska, Warszawa 1995, s. 13-25.

102 Zob. G. Bataille, Erotyzm, Gdańsk 1999, s. 140.

103 Zob. tegoż, Historia erotyzmu, Warszawa 2008, s. 227 nn.

104 W. Klimczyk, Erotyzm ponowoczesny, Kraków 2008, s. 21-22.

105 L. Williams, Hard Core. Władza, przyjemność i ,, szaleństwo widzialności”, Gdańsk 2010, s. 201-206; W. Klimczyk, op. cit., s. 196-227. Zob. także D.B. Sova, 125 zakazanych filmów. His- 
wideo i interaktywnymi grami komputerowymi pornograficzne ruchome obrazy przeniosły się $\mathrm{z}$ wielkich ekranów na małe ekrany telewizorów i z publicznych kin do prywatnych domów ${ }^{106}$.

Fakt, że internet wydaje się zapewniać tak pożądaną anonimowość, a jednocześnie gwarantuje dostęp do treści, które w realnej rzeczywistości wydawać by się mogły trudno dostępne, a co najmniej wymagające ujawnienia tożsamości - co dla wielu odbiorców bywa trudne bądź krępujące - spowodował, że właśnie w internecie współczesny człowiek poszukuje przekazów z obszaru erotyki i seksu ${ }^{107}$. Jest to ubocznym skutkiem pojawienia się nowych koncepcji seksualności, feminizmu i teorii queer ${ }^{108}$. Nie przeczy temu fakt, iż seks, który od końca lat sześćdziesiątych stał się codziennością i na stałe przeniknął do kultury masowej, stał się przedmiotem naukowych, popularnonaukowych i publicystycznych rozważań ${ }^{109}$. Bardziej plastyczny i dosłowny przekaz internetowy wypiera w doskonały sposób to, co przekazywała literatura i sztuki plastyczne ${ }^{110}$. W dużej mierze były one jednak trudno dostępne dla przeciętnego odbiorcy. Drogą internetową udostępnia się filmy o charakterze erotycznym, często obsceniczne i niedopuszczone w wielu krajach do sal kinowych ${ }^{111}$.

Dostępne w internecie obrazy zachowań seksualnych nie mogą być obojętne z punktu widzenia prawa karnego, aczkolwiek prawo karne odnosi się z natury rzeczy do rzeczywistych, a nie wirtualnych zachowań. W internecie

toria cenzury w kinie, Warszawa 2006, passim. Zob. także A. Bazin, Ontologia obrazu fotograficznego, [w:] idem, Film i rzeczywistość, Warszawa 1963, s. 14 i n.

106 L. Williams, Hard Core..., s. 322. Zob. eadem, Seks na ekranie, Gdańsk 2013, passim.

107 Jako przyczyny sięgania po erotykę w sieci wskazuje się z jednej strony chęć autoprezentacji, upublicznienia swoich doświadczeń i przeżyć seksualnych, realizację potrzeb ekshibicjonistycznych. Widzi się w tym także sposób kompensowania niepowodzeń w realnym świecie. Czasem podnosi się, że strony o zawartości erotycznej służą także celom praktycznym, stanowiąc formę pozyskania sponsora lub partnera seksualnego. Motywem zakładania takich storn mogą być także względy finansowe, widoki na dochody uzyskiwane dzięki opłatom pobieranym za udostępnienie zdjęć, filmów czy przekazów. Internetowe sklepy $\mathrm{z}$ akcesoriami seksualnymi zapewniają anonimowość, eliminując lub ograniczając zażenowanie związanie z takimi zakupami. I. Ślęzak, Seks i erotyka w sieci, czyli czego poszukują internauci, [w:] Oblicza Internetu. Opus Universale. Kulturowe, edukacyjne i technologiczne przestrzenie Internetu, red. M. Sokołowski, Elbląg 2008, s. $148-151$.

108 Z. Melosik, Ciało, tożsamość, władza. Teksty kulturowe jako konteksty pedagogiczne, Poznań - Toruń 1996, passim; J. Mizielińska, Płeć, ciało, seksualność od feminizmu do teorii queer, Kraków 2006, s. 63-74 i 163-178.

109 W. Klimczyk, op. cit., s. 160-170.

110 Z. Wróbel, Erotyzm w literaturze nowożytnej, Łódź 1987, passim; P. Krakowski, Z rozważań nad sztuka erotyczna, [w:] Sztuka a erotyka..., s. 13-24; K. Jurecki, Między erotyzmem a pornografią. O sztuce amerykańskiej lat osiemdziesiatych i dziewięćdziesiatych, [w:] Sztuka a erotyka..., s. 415-432; por. także: G. Bataille, op. cit., s. 217-258; D. de Rougemont, Miłość a świat kultury zachodniej, Warszawa 1968, s. 211-227.

111 J. R. Petersen, Stulecie seksu. Historia rewolucji seksualnej1900-1999 wedtug „Playboya”, Poznań 2002, zwłaszcza s. 327-496. 
pojawiają się obrazy, fotografie, krótkie filmy uznawane za pornograficzne, częstokroć prezentujące rozmaite dewiacje seksualne. Zwraca uwagę różnorodność stanów faktycznych prezentowanych przy tej okazji. Filmowe przekazy internetowy mają przy tym różny charakter. $Z$ jednej strony prezentuje się wyreżyserowane, odgrywane przez mniej lub bardziej profesjonalnych aktorów, sceny zgwałcenia bądź stosowania przemocy fizycznej: bicia, znęcania się, z drugiej zamieszczane są przekazy niemające takiego charakteru, a prezentujące wbrew woli zainteresowanych filmowanych osób ich rozebrane ciała lub ich samych w trakcie stosunku seksualnego. Warto zauważyć, że stron internetowych o charakterze seksualnym jest obecnie blisko miliard. Niektóre $\mathrm{z}$ nich mają charakter charakter amatorski, inne są profesjonalne ${ }^{112}$. Stosunkowo nowym zjawiskiem jest uprawianie seksu na odległość, podglądanie scen erotycznych, czasem za zgodą ich uczestników, najczęściej jednak bez, prowadzenie intymnych dialogów połączone z przekazywaniem transmisji i obrazów nagranych kamerą wideo ${ }^{113}$. W literaturze podkreśla się, że wirtualne przygody seksualne są bezpieczniejsze od tych w realnym życiu, gdyż mniejsze jest szeroko rozumiane ryzyko z nim związane: możliwość zapadnięcia na choroby weneryczne, zajścia w ciążę, wykrycie zdrady przez stałego partnera. $Z$ drugiej strony intymne rozmowy prowadzone przez internet stwarzają zagrożenia dla stałości związku. Sceny erotyczne, zaspokajając ciekawość odnoszącą się do seksualności człowieka, stymulują jednocześnie jego potrzeby i pragnienia ${ }^{114}$. Nader często prezentowanie nagich ciał $w$ internecie następuje wbrew woli młodych ludzi, którzy na wykonanie takich zdjęć lub utrwalanie filmów nie tylko nie wyrazili zgody, ale wręcz się temu sprzeciwiali, względnie nie mieli świadomości wykonywania przez partnera seksualnego takich zdjęć bądź filmów. Wiąże się to również z przedmiotowym traktowaniem kobiet w niektórych subkulturach młodzieżowych.

Nie da także zaprzeczyć, że zarówno treści pornograficzne, jak i te, które nazywamy tylko „erotycznymi”, w dużej mierze bazują na nagości, na obrazie nagiego ciała człowieka, zwłaszcza kobiety, w trakcie aktu seksualnego. W literaturze podkreśla się, iż sama nagość przybliża odbiorcę do odpychającego centrum erotyzmu, aczkolwiek nie zawsze kojarzy się i nie musi kojarzyć się z nieprzyzwoitością aktu płciowego ${ }^{115}$. Wynalazek fotografii w zna-

112 Różnica między nimi jest w gruncie rzeczy umowna. Zob. M. Filiciak, Internet i rozrywka, [w:] Humanista w cyberprzestrzeni, red. F. Godzić, Kraków 1999, s. 56; M. Nowak, K. Kierc, Internet z perspektywy nauk społecznych, [w:] Społeczna przestrzeń Interentu, red. D. Batorski, M. Marody, A. Nowak, Warszawa 2006, s. 9.

113 A. Ben-Ze'ev, Miłość w sieci. Internet i emocje, Poznań 2005.

114 F. Bylok, Rynek i konsumpcja w społeczeństwie informacyjnym, [w:] Polskie doświadczenia $w$ ksztaltowaniu społeczeństwa informacyjnego. Dylematy cywilizacyjno-kulturowe, Warszawa 2002, s. 304

115 B. McNair, Seks, demokratyzacja pożądania i media, czyli kultura obnażania, Warszawa 2004, s. 41 nn.; G. Bataille, Historia erotyzmu, Warszawa 2008, s. 199 nn. Stwierdza się nawet, że: 
czącym stopniu wpłynął na jej rozpowszechnienie przez, jak stwierdza się w literaturze, naiwny realizm towarzyszący zdjęciom, które odnosiły się do sytuacji niedostępnych codziennemu oglądowi, a nie dość realistycznie oddawanych poprzez obrazy i ryciny ${ }^{116}$. Zdjęcia nagich postaci zwróciły uwagę na konieczność określenia granic miedzy erotyką a pornografią ${ }^{117}$. Jeszcze większy wpływ na rozwój zjawiska pornografii miał film, który wymagał znacznie mniejszego niż fotografia udział wyobraźni. Zasadnicza różnica polegała jednak na tym, że zdjęcia zwykle odbierano prywatnie, natomiast film odtwarzany był w obecności szerszej widowni. Dlatego, jak stwierdza L.M. Nijakowski, dla rozwoju pornografii filmowej kluczowe znaczenie miał stopień liberalizmu systemu prawnego w danym kraju i swoboda obyczajowa ${ }^{118}$. Wraz z rozwojem kinematografii zaczął kształtować się system cenzury filmowej, także o charakterze obyczajowym ${ }^{119}$. Zauważa się także, że przekazy erotyczne, a zwłaszcza pornograficzne, koncentrują się na pokazywaniu kobiety w stanie uniesienia, a celem pornografii nie jest zrozumienie źródła i natury tych uniesień, ani ich przeżywania, lecz ich oswojenie ${ }^{120}$.

Dopiero ostatnio, wraz ze zmianą norm obyczajowych, wyzwoleniem kobiety z gorsetu konwenansów, powszechnego uznania jej za podmiot mający prawo do seksualności, marzeń i oczekiwań seksualnych, pojawiło się zjawisko przekazów pornograficznych wyraźnie adresowanych do kobiet ${ }^{121}$. Rola

„Z męskiego punktu widzenia najprzyjemniejszym wątkiem w dziejach ludzkości jest ten dotyczący rozbierania się i ubierania kobiety. Zakrywanie i odkrywania ciała jest jednym z najprostszych i najbardziej ekscytujących działań ludzkości. Podniecające jest nie tylko to, co można zobaczyć, ale przede wszystkim to, co myślimy, że można zobaczyć”, zob. G. Sieczkowski, Cały ten seks. Kroniki podkasane, Warszawa 2008, s. 1.

116 S. Sikora, Fotografia między dokumentem a symbolem, Izabelin 2004, passim; L.M. Nijakowski, op. cit., s. 161-164.

117 M. Filar, Pornografia a sztuka, „Nowe Prawo”, 1978, nr 10. Zob. także B. Kunicka-Michalska, Pornografia i wykorzystywanie nieletnich $w$ Internecie. Regulacje polskiego kodeksu karnego, ,Studia Prawnicze”, 2005, nr 4 (166), s. 77-108.

118 Już w wilhelmińskich Niemczech przedstawienie nagiego ciała człowieka było całkowicie niedozwolone. L.M. Nijakowski, op. cit., s. 170.

${ }^{119}$ W 1915 r. Sąd Najwyższy Stanów Zjednoczonych uznał, że film jest przedsięwzięciem o charakterze komercyjnym, a więc nie mają w stosunku do niego zastosowania przepisy stojące na straży wolności słowa. Pozwoliło to na działanie licznych komisji o charakterze cenzorskim, tworzenie kodeksów mających na celu ochronę moralności. Dopiero na kanwie sprawy z 1952 r. Burstyn przeciwko Wilson przyznano filmowi ochronę, odchodząc od koncepcji cenzury prewencyjnej. Ostatecznie jednak nastąpiło to w 1965 r. Od tej chwili przeciwnicy rozpowszechniania filmu muszą dowieść, że ma on charakter ,obsceniczny”. Nadal jednak funkcjonuje system klasyfikacji filmów, podobny do tego, który znany jest w Polsce w ustawie o radiofonii i telewizji. Zob. D.B. Sova, op. cit., s. 15.

120 Zob. A. Giddens, Przemiany intymności. Seksualność, miłość i erotyzm we wspólczesnych społeczeństwach, Warszawa 2006, s. 146. Por. także A. Moye, Pornography, [w:] A. Metcalf, M. Humpries, The sexuality of Men, Londyn 1985, s. $68 \mathrm{nn}$.

121 Pornografia wydawać się może niejednokrotnie bezsensowna w swoim wyuzdaniu, ale tak naprawdę u podstaw jest niezwykle racjonalna. Widoczna w jej obrębie specjalizacja, standaryzacja i schematyzm świadczą o tym dobitnie. Pornografia niczym szkoło powiększające pokazuje ambi- 
kobiety w społeczeństwie, jej prawo do przeżyć seksualnych ulegały w toku historii poważnym zmianom ${ }^{122}$. Przekazami erotycznymi, a może wręcz pornograficznymi, przesycone są liczne pisma adresowane do kobiet, chociażby takie jak „Cosmopolitan”, aczkolwiek nie ma periodyku, który zawierałby wyłącznie treści pornograficzne przeznaczone dla kobiet.

Seksualizacja kultury związana z szeroką zmianą społeczną, będąca - jak stwierdza się w literaturze - pochodną przełomowych wynalazków technologicznych oraz nacisków komercjalnych, prowadzi m.in. do medialnej dostępności seksu, obscenicznego zainteresowania nagością, ekshibicjonizmu. Środki społecznego przekazu tworzą kulturę, w której publiczna nagość, voyeuryzm są dozwolone. Epatują nagością nie tylko pisma uznawane za pornograficzne, lecz także te, które zaliczane są do czasopism poważnych, a nawet popularno-naukowych ${ }^{123}$. Podkreśla się, że w latach dziewięćdziesiątych XX w., „dotrzymując kroku postmodernistycznym nastrojom tej dekady, pornograficzna ikonografia w obfity sposób zamieszczała przyjemne erotyczne obrazki jako przedstawienia mody, a nie pornografii" ${ }^{124}$. Okazało się w tym czasie, iż roznegliżowane modelki na okładkach i towarzyszące im „obiecujące”, przesycone erotyzmem zapowiedzi artykułów, w sposób znakomity wpływają na zwiększenie sprzedaży czasopism. Dodać należy, że niejako przy okazji stwierdzono, że odwoływanie się do nagości i seksu, czasem

walencję naszych czasów, rezygnację z kodeksów ugruntowanych religijnie bądź zwyczajowo zasad na rzecz toczących się wciąż moralnych negocjacji. Pokazuje nasze marzenia o raju, w którym każdy żyje tak jak chce, jak mu dyktuje serce i równoczesną niemożliwość wyswobodzenia się z racjonalnego kieratu. Najważniejszą charakterystyką pornografii wcale nie jest jej nieracjonalność, a jedynie pragnienie by taką być. W. Klimczyk, op. cit., s. $138 \mathrm{nn}$. W literaturze zauważa się, że pornografia ma służyć zrozumieniu mechanizmu rozkoszy, i to rozkoszy kobiecej. Obsesyjne ukazywanie najrozmaitszych form aktu płciowego jest próbą rekonstrukcji logiki przyjemności. L. Williams, Hard Core ..., s. 187. Por. także N. Prause, D.R. Steele, C. Stanley, D. Sabatinelli, G. Hajcak, Modulation of late positive potentials by sex ual images inconsistent with sex addiction, ,Biological Psychology", 2015, nr 109, s. 192-199 http://www.researchgate.net/publication/278037398_Modulation_of_late_positive_potentials_by_sexual_images_in_problem_users_and_controls_inconsistent_with_porn_addiction, [dostęp: 19.07.2015, 12:44].

$\overline{122} \mathrm{~W}$ średniowieczu rozważano nawet czy kobietę w ogóle można uznać za człowieka, zważywszy, że na podobieństwo Boga został stworzony Adam, a Ewa jedynie jako odwzorowanie Adama. Kobieta uważana była przez wieki za stworzenie nieczyste, skłonne do grzechu, zdradliwe, a więc niebezpieczne dla rodu. Żydzi dziękowali Bogu za to, że nie urodzili się kobietą, a w buddyzmie wcielenie wędrującej duszy w kobietę uważano za karę i degradację. W islamie wyraźnie wskazywano, że „mężczyźni mają pierwszeństwo nad kobietami, ponieważ Bóg dał im wyższość nad nimi”. K. Pytko, Staba, piękna czy gorsza?, [w:] Pleć - sex-gender. Trzecia, czwarta, piąta płeć, Warszawa 2014, s. 20-25. Por. A. Kusiak, O historii kobiet, [w:] E. Pakszys, D. Sobczyńska, Humanistyka i pleć, t. II: Kobiety w poznaniu naukowym wczoraj i dziś, Poznań 1997, s. 197-219; E. Pakszys, Feministyczna rewindykacje wobec nauk o życiu albo o roli ptci/rodzaju w poznaniu biologicznym, [w:] E. Pakszys, D. Sobczyńska, Humanistyka i płeć... , t. II, s. 263-283; G.R. Taylor, The Science of Life. A Picture History of Biology, New York-Toronto 1963.

123 Ważną datą dla problematyki pornografii było ukazanie się w 1953 r. pisma „Playboy”.

J.R. Petersen, op cit., passim. Zob. także B. McNair, op. cit., s. 5, 21.

124 Ibidem, s. 159. 
powiązanego z ironią i humorem, jest dobrym zabiegiem w reklamowaniu różnych towarów. Rozwój fotografii cyfrowej, pozwalającej na daleko idącą manipulację, doprowadziły do głębokich przemian społecznych, zwłaszcza w momencie, kiedy pozornie anonimowy, a w każdym razie uchodzący za takowy, internet pozwolił na masowe rozpowszechnianie tego typu zdjęć ${ }^{125}$. Warto zauważyć, że postrzeganie nagości nie jest niezależne od norm kulturowych. Interpretacja wizerunku nagiego człowieka zależy od punktu widzenia lub ram, jakie przyjmuje odbiorcy. W literaturze wskazuje się, że mogą być to ramy sztuki, pornografii, informacji i reklamy. Istotą wydaje się być seksualizacja wstydu ${ }^{126}$.

Jakkolwiek obsceniczne obrazy towarzyszą cywilizacji ludzkiej od samego zarania dziejów, to jednak pornografia jako czyn wyczerpujący znamiona przestępstwa pojawiła się dopiero w epoce nowożytnej. Terminem ,pornografia” określa się ,,pisma, druki, przedstawienia teatralne, filmy, zdjęcia, obrazy, rysunki i inne przedmioty o treści nieprzyzwoitej, obliczone na wywoływanie podniecenia erotycznego u odbiorców" ${ }^{127}$. Nieco odmienne thumaczy ten termin Uniwersalny słownik języka polskiego pod red. S. Dubisza, wskazując, że pornografia to ,pisma, filmy, zdjęcia, itp., pokazujące nagie ciała (często z odsłoniętymi organami płciowymi), stosunki seksualne w sposób naruszający społeczne normy obyczajowe". W doktrynie zwykło się odróżniać pornografię ,twardą” od „miękkiej”. Pornografia miękka według tego słownika to „pornografia łagodna, pozbawiona agresji i patologii”. Natomiast pornografia twarda to ,,pornografia pełna agresji, przestawiająca często patologiczne stosunki płciowe"128. Niekiedy wyróżnia się w literaturze dodatkowo pornografię dziecięcą (pedofilię). Wskazuje się zwykle, że określenie ,pornografia" pochodzi od greckiego słowa porno, używanego na określenie prostytucji i słowa graphos - ,piszę”. Określenie to nie było jednak znane w klasycznej

125 K. Olechnicki, Fotoblogi, pamiętniki z opcją przekazu. Fotografia i fotoblogerzy w kulturze konsumpcyjnej, Warszawa 2009, s. 83-102; L. Manovich, Język nowych mediów, Warszawa 2006, s. 124-127; B. Kunicka-Michalska, Przestępstwa przeciwko wolności seksualnej i obyczajności popetniane za pośrednictwem systemu informacyjnego, Warszawa 2004, s. 89; Z. Lew-Starowicz, Seks w sieci i nie tylko, Kraków 2003, s. 58 nn.

126 L.M. Nijakowski, op. cit., s. 328; B.A. Eck, Nudity and Framing: Classifying Art., Pornography, Information and Ambiguity, ,Sociological Forum”, 2001, t. 16, nr 4, s. 604.

127 Zob. Stownik języka polskiego, t. II, s. 823.

128 Zob. Uniwersalny słownik języka polskiego, t. III, s. 387. J.R. Kirk zalicza do pornografii twardej treści, które ukazują akty bestialskie, tortury, oddawanie moczu, kazirodztwo, zniewalanie, gwałt, pseudodziecięcą pornografię oraz sadomasochizm. Do pornografii miękkiej zalicza stosunek dopochwowy między jedną kobieta a jednym mężczyzną. J.R. Kirk, Szkodliwość pornografii, Gdańsk 1998, s. 3. J. Warylewski zwraca uwagę, że w tym ujęciu brak miejsca na pornografię dziecięcą. Zob. J. Warylewski, Pornografia - próba definicji, [w:] Pornografia, red. M. Mozgawa, Warszawa 2011, s. 23. Z.L. Starowicz do pornografii miękkiej zalicza ekspozycję genitalną, praktyki masturbacyjne, stosunki w różnych pozycjach i typowe w danej obyczajowości zachowania seksualne. Jako pornografię twardą traktuje treści ze scenami przemocy, pedofilii i zoofilii. Z.L. Starowicz, Seksuologia sądowa, Warszawa 2000, s. 408-409. 
grece $^{129}$. Od połowy XIX w. termin ,pornografia” używany był w nieco innym niż obecnie znaczeniu i określano nim utwory literackie, a także naukowe, które zajmowały się zjawiskiem prostytucji. Odnoszono ten termin także do sztuk teatralnych i sztuk operowych, których tematem były kurtyzany ${ }^{130}$. W literaturze podnosi się, ze określenia tego użyto prawdopodobnie po raz pierwszy na początku XIX w. w odniesieniu do powieści Justyna czyli nieszczesścia cnoty markiza Donatiena Alphonse François de Sade'a. Zauważyć należy, że de Sade pozostawił trzy wersje Justyny... Pierwsza z nich, Niedole cnoty (Les Infortunes de la vertu), napisana została w 1787 r., a wydana dopiero w 1930 r., druga, zatytułowana Justyna czyli nieszczęścia cnoty, została wydana w 1791, trzecia - najobszerniejsza, opublikowana została w $1797 \mathrm{r}$. pod tytułem Justyna - nowa Justyna ${ }^{131}$. Według Briana McNaira pornografia w dzisiejszym rozumieniu tego słowa zaistniała w Europie dopiero w 1530 r., wraz opublikowaniem przez włoskiego poetę Aretino serii sonetów o treści pornograficznej, które rozpowszechniano wraz z szesnastoma śmiałymi ilustracjami Geromano, ucznia samego Rafaela ${ }^{132}$.

W prawie europejskim aż do połowy XVII w. brak było jakiejkolwiek karnoprawnej reglamentacji pornografii. Termin ten zresztą nie występował ani w języku prawnym, ani w prawniczym. To co dzisiaj określane jest dzisiaj nosi miano pornografii określone było dawniej jako treści niemoralne, sprośne, obleśne, obsceniczne, plugawe, nieobyczajne - czyli takie, które naruszają poczucie wstydu i moralności płciowej. Dopiero w 1642 r. w Austrii ordonans Ferdynanda III zakazał sprzedaży przedmiotów sprośnych oraz uznał za przestępstwo drukowanie, sprzedawanie lub rozpowszechnianie książek lub paszkwili ,przeciw religii, służbie króla, dobru Państwa i czystości obyczajów”. Nieco później, bo w 1668 r., pojawiła się próba zdefiniowania pornografii, a w zasadzie dzieł obscenicznych, w rozprawie Johannesa Dawida Schrebera z Miśni De libris obsceanis (O księgach nieprzyzwoitych). Stwier-

129 Zob. F.S.P. Dufour, Historia prostytucji od czasów najdawniejszych do XX w., t. 1: Czasy przedchrześcijańskie, Gdynia 1997, s. 63-131 nn.; C. Reinsberg, Obyczaje seksualne starożytnych Greków, Gdynia 1998, s. 68-107.

${ }^{130}$ H.N. Parker, Love's body anatomized: the ancient erotic handbooks and the rhetoric of sexulity, [w:] Pornography and representation in Ancient Rome, red. A. Richlin, New York 1992, s. 90; A. Krawulska-Ptaszyńska, Społeczne skutki upowszechnienia pornografii, „Ruch Prawniczy, Ekonomiczny i Socjologiczny", 1997, z. 1, s. 145.

131 Zob. M. Bratuń, Postowie, [w:] D.-A.-F. de Sade, Justyna czyli nieszczęścia cnoty, Łódź 1987, s. 238-239. Por. także K. Matuszewski, Sade. Msza okrucieństwa, Gdańsk 2008, s. 42-45. Zob. też M. Praz, Zmysty, śmierć i diabet w literaturze romantycznej, Gdańsk 2010, s. 106-111; R. Shattuck, Zakazana wiedza. Od Prometeusza do pornografii, Kraków 1999, s. 277 nn.

132 Zob. idem, Mediated Sex. Pornography \& Postmodern Culture, Londyn-Nowy Jork-Sydney-Auckland 1996, s. 42-43. Zob. także J. Warylewski, uwagi do art. 202 k. k., [w:] A. Wąsek, R. Zawłocki, Kodeks karny. Czesść szczególna, komentarz do art. 117-221, t. I, wyd. 4, Warszawa 2010, s. 1100-1101. Por. także J. Warylewski, Przestępstwa przeciwko wolności seksualnej i obyczajności. Rozdziat XXV Kodeksu karnego. Komentarz, Warszawa 2001, s. 189-191. 
dził on, że obsceniczne są te pisma, których autor „wyraźnie ku nierządnej mowie zmierza, a bezczelne części lub akty wstydliwe lubieżnych ludzi tak opisuje, że niewinne i delikatne uszy odstrasza". Po Austrii podobne zakazy wprowadzono w Anglii w 1727 r. i we Francji w 1797 r. Kodeks karzacy Królestwa Polskiego z 1818 r. przewidywała karę zamknięcia w domu aresztu publicznego od trzech miesięcy do roku, gdy ktoś „,publicznie mową, pismem, sztychem lub drukiem dobre obyczaje kazi”. Sytuacji, gdy takiego przestępstwa dopuszczał się drukarz lub księgarz, należało orzec przypadek zakazanych towarów, a w razie stwierdzenia, iż po raz trzeci dopuścił się takiego występku, tracił on prawo wykonywania zawodu ${ }^{133}$.

W doktrynie podkreśla się, że wszystkie definicje pornografii są w mniejszym lub większym stopniu ułomne ${ }^{134}$. Wydają się wystarczająco precyzyjne w potocznym rozumieniu tego terminu, jednak w obszarze prawa karnego budzą najczęściej wątpliwości. W literaturze, jeszcze w okresie międzywojennym, akcentowano, że powodem kryminalizacji pornografii jest niebezpieczeństwo obrażenia poczucia wstydliwości i publicznej moralności oraz możliwość wywołania podniecenia płciowego ${ }^{135}$. Podkreślano także, że decydujące znaczenie ma zamiar sprawcy, który aby wyczerpać znamiona przestępstwa, winien działać w celu rozbudzenia lub podniecenia pobudliwości płciowej albo oddziaływania na uczucia seksualne ${ }^{136}$. Nieco inaczej spoglądał

133 Cyt. za J. Warylewski, uwagi do art. 202 k. k., op. cit., s. 1101.

134 Próby zdefiniowania pornografii dzieli się zwykle na dwie grupy, wyróżniając definicje subiektywistyczno-moralistyczne, opierające się na elemencie zamiaru sprawcy, aby określoną prezentacją wywołać podniecenie seksualne u odbiorcy i definicje obiektywno-pragmatyczne, zasadzające się nie na elemencie zamiaru sprawcy lecz obiektywnej treści i na obiektywnych skutkach (domniemanych lub rzeczywistych) określonej prezentacji. Zob. M. Filar, Przestępstwa seksualne w polskim prawie karnym, Toruń 1985, s. 113-118. Wskazuje się, że istotne znaczenie ma podział na ,pornografię klasyczną” i ,pornografię dewiacyjno-perwersyjną”. Pierwsza z nich stanowi prezentację przejawów seksu niesprzecznych z jego naturalnym biologicznym ukierunkowaniem i w formach wykonawczych tolerowanych społecznie, jeżeliby nawet niektóre $\mathrm{z}$ nich uwzględniały wyłącznie warstwę hedonistyczną seksu, z wykluczeniem warstwy prokreacyjnej, lub przybierały formy wyszukane. Zaliczamy tu głównie prezentację nagości, heteroseksualny petting, w tym także w formie fellatio i cunnilingus, oraz heteroseksualne stosunki, także w formach akrobatycznych i wyszukanych. Pornografia dewiacyjno-perwersyjna obejmowałaby prezentacje seksu sprzecznego z jego biologicznym ukierunkowaniem oraz seksu w nietolerowanych społecznie (lub także i prawnie) formach, które zakładają eksploatację jednego z uczestników stosunku, w szczególności eksploatację polegającą na naruszaniu w związku z aktem seksualnym innych, pozaseksualnych dóbr prawnie chronionych. Zaliczymy tu więc prezentacje seksu homoseksualnego i lesbijskiego we wszystkich jego wariantach, seks sadystyczny i połączony z gwałtem i przemocą, seks pedofilski, kazirodczy, nekrofilski i zoofilski. Zob. M. Filar, Pornografia. Studium ..., s. 140.

135 L. Peiper, Komentarz do kodeksu karnego, Kraków 1936, s. 580 nn.

136 S. Śliwiński, Prawo karne materialne. Część szczególna, Warszawa 1948, s. 136-137; S. Śliwiński wykluczał, aby pornograficzny charakter mogły mieć dzieła dotyczące anatomii ciała ludzkiego o chorobach wenerycznych, prostytucji jako zagadnieniu społecznym, dzieła medycyny sądowej odnoszące się do przestępstw seksualnych, komentarze i opracowania dotyczące przestępstw seksualnych, ilustracje, filmy i fotografie sporządzone dla celów naukowych, zauważając jednak, że 
na problem pornografii M. Siewierski, który w treści komentarza do Kodeksu karnego z 1969 r. zauważył, że pornografia ma na celu podniecenie pobudliwości płciowej, przy czym rozstrzygające znacznie ma „subiektywny nastrój woli twórcy", odbijający się w samym dziele ${ }^{137}$. Stanowisko to zdawał się podzielać M. Filar, podnoszący, że do okoliczności, które mogą decydować o uznaniu prezentacji pewnych treści za pornografię należy charakter prezentowanych czynności seksualnych, które stają się pornograficznymi, jeżeli w zdecydowany sposób odbiegają od uznawanych standardów społecznych w tym zakresie. Zauważyć przy tym należy, że pojęcie „uznawanych standardów społecznych" jest wyjątkowo nieostre, a same standardy różnią się w zależności od tego, jaka grupa społeczna staje się przedmiotem dociekań. Zmieniają się one także w czasie. Zdaniem M. Filara pornograficzny charakter mają przekazy, w których przedstawia się przejawy płciowości i życia płciowego człowieka, koncentruje się wyłącznie na technicznych aspektach życia płciowego z oderwaniem od warstwy intelektualnej i osobistej, ukazuje się ludzkie organy płciowe w ich funkcjach seksualnych, w bezpośrednim zetknięciu podczas stosunku, sprowadzając do rejestracji zdepersonalizowanej i odhumanizowanej i akcentującej stronę technologii seksu. Cechy te winny wskazywać jednoznacznie, że jedyną lub główną intencją twórcy było wywołanie podniecenia seksualnego u odbiorcy. Wszystkie te elementy winny wystąpić łącznie. Kryterium pomocniczym jest walor estetyczny. Im jest on niższy, tym bliżej takim treściom do pornografii ${ }^{138}$.

J. Warylewski stoi na stanowisku, że pornografia w wąskim, czyli normatywnym rozumieniu tego słowa oraz synonimiczne $\mathrm{z}$ nią treści pornograficzne, którym to terminem posługuje się chociażby art. $202 \S 1-4 \mathrm{~b} \mathrm{K.K.}$ z 1997 r., to ,treści zawarte w dającym się wyodrębnić przekazie informacyjnym (prezentacji) bądź w jego istotnych i odpowiednio spójnych fragmentach, w formie materialnej lub zdematerializowanej, utrwalone za pomocą dowolnego nośnika lub nieutrwalone, charakteryzujące się tym, że przedstawiają w jakiejkolwiek formie autentyczne lub tylko wyobrażone (wykreowane) przejawy połciowości lub życia seksualnego człowieka, w wymiarze ograniczonym (sprowadzonym) do funkcji fizjologicznych oraz aspektów technologiczno-biologicznych"139. Autor ten zwraca uwagę, że terminem „treści pornograficzne” posługuje się art. 202 K.K., natomiast określenie ,pornogra-

zamieszczenie takowej ikonografii w czasopiśmie powoduje zerwanie związku z celem godziwym. Odnosił to także do twórczości artystycznej.

137 M. Siewierski, [w:] J. Bafia, K. Mioduski, M. Siewierski, Kodeks karny. Komentarz, s. 147.

138 M. Filar, Pornografia, „Przegląd ustawodawstwa gospodarczego”, 1993, nr 8-9, s. 24 nn.; idem, Przestępstwa seksualne..., s. 113.

139 J. Warylewski, Pornografia - próba definicji..., s. 25. Por. także idem, Przestępstwa seksualne, Gdańsk 2001, s. 254 nn.; idem, Sprośne rysunki, [w:] Fascynujące ścieżki filozofii prawa, red. J. Zajadło, Warszawa 2008, s. 41-55. 
fia" występuje w ratyfikowanych przez Polskę i obowiązujących umowach międzynarodowych, a także $\mathrm{w}$ aktach prawa unijnego. W judykaturze podkreśla się, że termin treści pornograficzne, użyty w dyspozycji art. 202 K.K. jest pojęciem prawnym, a nie medycznym czy seksuologicznym. Wskazuje się przy tej okazji, że biegły seksuolog posiada wiadomości specjalne w zakresie ustalenia hipotetycznego wpływu danej prezentacji na potencjalnego odbiorcę, w płaszczyźnie jego reakcji emocjonalnych w tym seksualnych, ale nie jest $\mathrm{w}$ stanie zastąpić sądu w ocenie, czy przekaz ma charakter pornograficzny. Podkreślono przy tym, że istotą pornografii jest przekaz określonej idei (treści), a nie jedynie udokumentalizowana rejestracja danego zdarzenia faktycznego. Wskazano, że dzieła artystyczne, a także naukowe, mogą jednocześnie zawierać treści pornograficzne, a brak karalności produkcji, prezentacji i rozpowszechniania takich dzieł wynika $\mathrm{z}$ istnienia pozaustawowego kontratypów sztuki i nauki. Sformułowanie „treści pornograficzne związane z prezentowaniem przemocy", użyte w art. 202 § 3 K.K., obejmuje swoim zakresem także przedstawianie odegranych przez aktorów scen przemocy, jak też tego rodzaju sceny wytworzone za pomocą różnych innych technik wizualizacji $^{140}$.

Społeczność międzynarodowa podejmowała już w początkach XX w. próbę ograniczenia rozpowszechniania pornografii. W dniu 4 maja 1910 r. zawarto tzw. porozumienie paryskie zobowiązujące państwa do utworzenia lub wyznaczenia urzędu, który zbierałby dane mogące zapobiec wwozowi literatury nieprzyzwoitej oraz ułatwiał walkę z rozpowszechnianiem pism, rysunków, obrazów i przedmiotów nieprzyzwoitych. Polska ratyfikowała porozumienie paryskie ${ }^{141}$. Na zaproszenie rządu francuskiego zorganizowano w $1923 \mathrm{r}$. konferencję w Genewie, której wynikiem było podpisanie konwencji w sprawie zwalczania obiegu i handlu wydawnictwami pornograficznymi ${ }^{142}$. Polska ratyfikowała tę umowę międzynarodową w dniu 8 marca 1927 r. Powołana konwencja (podobnie jak i umowa paryska z 1910 r.), uznała, że należy pozostawić każdemu państwu staranie o ustalenie definicji pojęcia ,pornograficzny" (obscène).

W ratyfikowanej przez Polskę Dyrektywie Parlamentu Europejskiego i Rady z dnia 13 grudnia 2011 r. w sprawie zwalczania niegodziwego traktowania w celach seksualnych i wykorzystywania seksualnego dzieci oraz pornografii dziecięcej, zastępującej decyzję ramową Rady 2004/68/WSiSW ${ }^{143}$ stwierdzono, iż pornografią dziecięcą są: „obrazy przedstawiające niegodziwe

140 Zob. wyrok Sądu Najwyższego z dnia 23 listopada 2010r. IV K.K. 173/10, LEX nr 667510, glosa aprobująca M. Budyn-Kilk, LEX/L 2011.

141 Dz. U. z 1922, Nr 21, poz. 167.

142 Tekst konwencji z 12 września 1923 r. zam. Dz. U. z 1927, Nr 71, poz. 621.

143 Dz. Urz. UE L 2011, nr 335, str. 1. Tytuł Dyrektywy został zmieniony przez sprostowanie z dnie 21 stycznia 2012 r. sprost. Dz. Urz. UE L 2012, nr 18, str. 7. 
traktowanie dzieci w celach seksualnych oraz inne szczególnie groźne formy niegodziwego traktowania w celach seksualnych i wykorzystywania seksualnego dzieci, jest przedmiotem coraz intensywniejszego obiegu i upowszechnia się poprzez wykorzystanie nowych technologii i internetu". Wspomniana Dyrektywa odwołuje się w swej treści do Konwencji o prawach dziecka, przyjętej przez Zgromadzenie Ogólne Narodów Zjednoczonych dnia 20 listopada 1989 r. ${ }^{144} \mathrm{~W}$ tym kontekście należy pamiętać, że w rozumieniu Konwencji ,«dziecko» oznacza każdą istotę ludzką w wieku poniżej 18 lat, chyba że zgodnie z prawem odnoszącym się do dziecka uzyska ona wcześniej tożsamość".

Wspomniana Dyrektywa Parlamentu Europejskiego i Rady poprzedzona była najpierw decyzją Rady z dnia 29 maja 2000 r. w sprawie zwalczania pornografii dziecięcej w internecie 2000/375/WSiSW ${ }^{145}$, która odwoływała się do Rezolucji Rady i przedstawicieli rządów Państw Członkowskich zebranych w Radzie w dniu 17 lutego 1997 r. w sprawie nielegalnych i szkodliwych treści rozpowszechnianych w internecie ${ }^{146}$ oraz wspólnego działania Rady 96/700/WSiSW z dnia 29 listopada 1996 r. ustanawiającego program zachęty i wymiany dla osób odpowiedzialnych ze zwalczanie handlu ludźmi i wykorzystywanie seksualnych dzieci ${ }^{147}$ oraz wspólne działanie 97/154/ WSiSW z dnia 24 lutego 1997 r. przyjęte przez Radę na podstawie art. K. 3 Traktatu Unii Europejskiej, dotyczące działań mających na celu zwalczanie handlu ludźmi i seksualnego wykorzystywania dzieci ${ }^{148}$. Decyzja z 29 maja 2000 r. uwzględniała również zalecenie przyjęte przez Radę w dniu 24 września 1998 r. w sprawie rozwoju konkurencyjności europejskiego przemysłu usług audiowizualnych i informacyjnych przez wspieranie krajowych programów ramowych w celu zapewnienia skutecznego i porównywalnego poziomu ochrony nieletnich i godności ludzkiej ${ }^{149}$.

Kolejnym aktem poprzedzającym Dyrektywę Parlamentu Europejskiego i Rady z dnia 13 grudnia 2011 r. w sprawie zwalczania niegodziwego traktowania w celach seksualnych i wykorzystywania seksualnego dzieci oraz pornografii dziecięcej, zastępująca decyzję ramową Rady 2004/68/WSiSW była Dyrektywa ramowa Rady 2004/68/WSiSW z dnia 22 grudnia 2003 r., dotycząca zwalczania seksualnego wykorzystania dzieci i pornografii dziecięcej $^{150}$. Dokument ten przyjmując, że dziecko oznacza każdą osobę w wieku poniżej 18 lat, definiował pornografię dziecięcą jako materiał zawierający

\footnotetext{
144 Dz. U. 1991 Nr 120, poz. 526.

145 Dz. Urz. UE L 2000, nr 138, str. 1.

146 Dz. Urz. UE C 1997, nr 70, str. 1.

147 Dz. Urz. UE L 1996, nr 322, str. 7.

148 Dz. Urz. UE L 1997, nr 63, str. 2.

149 Dz. Urz. UE L 1998, nr 270, str. 58.

150 Dz. Urz. UE L 2004, nr 13, str. 44. W myśl art. 11 tej dyrektywy uchylone zostało wspólne działanie z dnia 24 lutego 1997 r., przyjęte przez Radę na podstawie art. K. 3 Traktatu o Unii Eu-
} 
treści pornograficzne, które przedstawia lub prezentuje: rzeczywiste dziecko uczestniczące w czynności wyraźnie seksualnej lub poddającego się takiej czynności, w tym lubieżne okazywanie narządów płciowych lub miejsc intymnych dziecka; rzeczywistą osobę, która sprawia wrażenie, że jest dzieckiem, uczestniczącą lub poddającą się czynności wyraźnie seksualnej; realistyczne obrazy nieistniejącego dziecka, uczestniczącego lub poddającego się czynności wyraźnie seksualnej. Wspomniana definicja została uzupełniona przez Dyrektywę Parlamentu Europejskiego i Rady 2011/92/UE w sprawie zwalczania niegodziwego traktowania w celach seksualnych i wykorzystywania seksualnego dzieci oraz pornografii dziecięcej, zastępująca decyzję ramową Rady 2004/68/WSiSW w art. 2c ${ }^{151}$, w którym stwierdzono, że ,pornografia dziecięca” oznacza: „,wszelkie materiały ukazujące dziecko uczestniczące w rzeczywistych lub symulowanych zachowaniach o wyraźnie seksualnym charakterze; wszelkie przedstawienia organów płciowych dziecka w celach głównie seksualnych; wszelkie materiały ukazujące osobę wyglądającą na dziecko uczestniczącą w rzeczywistych lub symulowanych zachowaniach o wyraźnie seksualnym charakterze oraz przedstawienia organów płciowych osób wyglądających jak dziecko, w celach głównie seksualnych; realistyczne obrazy dziecka uczestniczącego w zachowaniach o wyraźnie seksualnym charakterze lub realistyczne obrazy organów płciowych dziecka, w celach głównie seksualnych"152.

W Dyrektywie Parlamentu Europejskiego i Rady z dnia 13 grudnia 2011 r. w sprawie zwalczania niegodziwego traktowania w celach seksualnych i wykorzystywania seksualnego dzieci oraz pornografii dziecięcej, zastępująca decyzję ramową Rady 2004/68/WSiSW zauważono, iż „,usuwanie u źródła treści zawierających pornografię dziecięcą jest często niemożliwe w przypadku, gdy oryginalne materiały znajdują się poza terytorium Unii, ze względu na brak woli współpracy ze strony państwa, w którym znajdują się serwery, lub ze względu na to, że procedura prowadząca do usunięcia tych materiałów w danym państwie jest wyjątkowo długotrwała. Można zatem ustanowić także mechanizmy blokowania dostępu z terytorium Unii do stron internetowych,

ropejskiej dotyczące działań mających na celu zwalczanie handlu ludźmi i seksualnego wykorzystywania dzieci.

151 J. Warylewski w swoim niezwykle poważnym i potrzebnym studium mylnie stwierdza, że definicja ta znajduje się w art. 2b. R. Warylewski, Pornografia-próba definicji..., s. 25.

${ }^{152}$ Przy okazji stwierdzono, że „prostytucja dziecięca” oznacza „wykorzystywanie dziecka do czynności seksualnych, w ramach którego oferuje się lub obiecuje pieniądze lub inne formy wynagrodzenia lub świadczenia w zamian za udział dziecka w czynnościach seksualnych, niezależnie od tego czy zapłata, obietnica lub świadczenie przekazywane są danemu dziecku czy osobie trzeciej”, a „przedstawienie pornograficzne” oznacza „skierowane do publiczności ukazywanie na żywo, w tym za pośrednictwem technologii informacyjno-komunikacyjnych". Art. 2d i e Dyrektywy Parlamentu Europejskiego i Rady 2011/92/UE w sprawie zwalczania niegodziwego traktowania w celach seksualnych i wykorzystywania seksualnego dzieci oraz pornografii dziecięcej, zastępująca decyzję ramową Rady 2004/68/WSiSW, Dz. Urz. UE L 2011, nr 335, str. 1. 
w odniesieniu do których ustalono, że zawierają pornografię dziecięcą lub służą do jej rozpowszechniania. Środki podejmowane przez państwa członkowskie na mocy niniejszej dyrektywy w celu usunięcia lub, w odpowiednich przypadkach, blokowania stron internetowych zawierających pornografię dziecięcą mogą opierać się na różnych rodzajach działań publicznych, np. legislacyjnych, nielegislacyjnych, sądowych lub innych. W tym kontekście niniejsza dyrektywa nie stanowi uszczerbku dla dobrowolnych działań podejmowanych przez dostawców usług internetowych w celu zapobiegania niewłaściwemu wykorzystywaniu świadczonych przez nich usług ani dla jakiegokolwiek wsparcia tych działań ze strony państw członkowskich”. W art. 5 zobowiązano Państwa Członkowskie do podjęcia środków niezbędnych do zapewnienia karalności czynów umyślnych związanych z pornografią dziecięcą. Wskazano, że nabywanie lub posiadanie pornografii dziecięcej, świadome uzyskiwanie dostępu za pomocą technologii informacyjno-komunikacyjnych do pornografii dziecięcej podlegać winno sankcji karnej w wymiarze conajmniej roku pozbawienia wolności. Natomiast dystrybucja, rozpowszechnianie lub przesyłanie pornografii, a także oferowanie, dostarczanie lub udostępnianie pornografii dziecięcej winno być karane karą pozbawienia wolności wymiarze conajmniej dwóch lat. Produkcja pornografii dziecięcej zagrożona być winna maksymalną karą trzech lat pozbawienia wolności. W art. 25 ust. 1 wspomnianej Dyrektywy zobowiązano Państwa Członkowskie do podjęcia niezbędnych środków dla zapewnienia szybkiego usunięcia stron internetowych zawierających lub rozpowszechniających pornografię dziecięcą „utrzymywanych na ich terytorium" oraz do dążenia, aby zapewnić usunięcie takich stron ,utrzymywanych poza ich terytorium”. Stwierdzono także w ust. 2 art. 25, że Państwa Członkowskie mogą podejmować środki służące blokowaniu stron internetowych zawierających lub rozpowszechniających pornografię dziecięcą wśród użytkowników internetu. Dodano jednak, że środki te musza być wprowadzane w oparciu o przejrzystą procedurę i dostarczać odpowiednich gwarancji, w szczególności w celu zapewnienia ograniczenia blokowania do tego co jest konieczne $\mathrm{i}$ wspomniane oraz informowania użytkowników o powodach takiego blokowania. Zauważono, iż wspomniane gwarancje mogą również obejmować możliwość uzyskania zadośćuczynienia sądowego.

W obowiązującym kodeksie karnym pornografia nadal uznawana jest za przestępstwo i to w kilku odmianach. Ścigane jest zarówno publiczne prezentowanie treści pornograficznych w taki sposób, że może to narzucić ich odbiór osobie, która sobie tego nie życzy (art. $202 \S 1$ k.k.), jak i prezentowanie małoletniemu poniżej lat piętnastu treści pornograficznych albo udostępnianie mu przedmiotów mających taki charakter albo rozpowszechniania treści pornograficznych w sposób umożliwiający takiemu małoletniemu zapoznanie się z nimi (art. $202 \$ 2$ k.k.). Ponadto za przestępstwo uznano produkowanie 
w celu upowszechnienia, utrwalanie lub sprowadzanie, a także przechowywanie lub posiadanie albo rozpowszechnianie lub publiczne prezentowanie treści pornograficznych $\mathrm{z}$ udziałem małoletniego albo treści pornograficzne związane z prezentowaniem przemocy lub posługiwaniem się zwierzęciem (art. $202 \S 3$ k.k. $)^{153}$. Wypada w tym miejscu ze strachem zauważyć, że literalna językowa wykładnia tego przepisu mogłaby zaprowadzić na ławę oskarżonych wszystkich tych, którzy w domowych bibliotekach przechowują dramat „Romeo i Julia” Williama Shakespeare'a, „Lolitę” Vladimir Nobokova czy „Justynę” Markiza de Sade'a, zważywszy, że wobec mało precyzyjnego pojęcia pornografii dla niektórych przedstawicieli organów ścigania mogło by się okazać ważnym to, że zarówno Julia, jak i Lolita to z dzisiejszego punktu widzenia nieletnie, w dziele Markiza de Sade'a czytelnik epatowany jest stosowaniem przemocy. Przestępstwem jest także utrwalanie treści pornograficznych z udziałem małoletniego poniżej lat piętnastu (art. $202 \S 4$ k.k.) oraz sprowadzanie, przechowywanie, lub posiadanie takich treści z udziałem małoletniego poniżej lat piętnastu, a także produkowanie, rozpowszechnianie, prezentowanie, przechowywanie lub posiadanie treści pornograficznych przedstawiających wytworzony lub przetworzony wizerunek małoletniego uczestniczącego w czynności seksualnej (art. $202 \S 4$ b k.k.). Rzeczywiście groźnym zjawiskiem jest przestępstwo z art. 191a k.k. ${ }^{154}$, polegające na utrwalaniu wizerunku nagiej osoby lub osoby w trakcie czynności seksualnej przy użyciu wobec takiej osoby przemocy, groźby bezprawnej lub podstępu albo na rozpowszechnianiu takiego wizerunku bez zgody takiej osoby ${ }^{155}$.

153 Zob. J. Warylewski, Pornografia, [w:] idem, Przestepstwa przeciwko dobrom indywidualnym, „System Prawa Karnego”, t. X, Warszawa 2012, s. 809-882; idem, [w:] Kodeks karny. Komentarz, red. R.A. Stefański, wyd. 2, Warszawa 2015, s. 1266-1278.

154 Jak wskazuje M. Mozgawa, występek ten, pomieszczony w rozdziale przestępstw przeciwko wolności winien znaleźć się w ramach rozdziału kodeksu karnego grupującego przestępstwa przeciwko wolności seksualnej i obyczajności, gdyż dobrem chronionym jest w tym przepisie obyczajność, intymność i prywatność człowieka. M. Mozgawa, Przestępstwa przeciwko wolności, [w:] Kodeks karny. Praktyczny komentarz, red. M. Mozgawa, Warszawa 2010, s. 391. Zob. także W. Wróbel, Opinia prawna o rzadowym projekcie ustawy o zmianie ustawy - Kodeks karny, ustawy - Kodeks postepowania karnego, ustawy - Kodeks karny wykonawczy, ustawy - Kodeks karny skarbowy oraz niektórych innych ustaw, druk sejmowy nr 1394.

155 B. Filek, Wizerunek osoby nagiej jako znamię przestępstwa z art. 191 a $\$ 1$ k.k., „Prokuratura i Prawo", 2012, nr 7-8, s. 61-77. Stanowisko to wypracowane przez M. Mozgawę, Kodeks karny. Praktyczny..., s. 391 akceptuje go J. Kosonoga wskazując, że z treści przepisu art. 191a § 1 k.k. wynika, że w pojęciu nagości chodzi o intymne części ciała, zob. J. Kosonoga, Karnoprawna ochrona intymnego wizerunku osoby, [w:] Studia i analizy Sadu Najwyższego, t. V, red. K. Slebzak, Warszawa 2011, s. 224. Zdaniem B. Fileka wizerunek osoby na fotografii przedstawiający ją bez ubrania, ale od pasa do głowy włącznie nie będzie stanowił przedmiotu czynności wykonawczej czynu zabronionego $\mathrm{z}$ art. 191a $\S 1$ k.k. Ten ostatni autor wyraża także pogląd, że zakresu pojęcia wizerunku osoby należy wyłączyć wizerunek nagich zwłok ludzkich. To ostatnie stanowisku wydaje się dość dyskusyjne, zob. B. Filek, op. cit, s. 61 nn. Pogląd ten podziela R. Krajewski zauważając, że gdyby doszło do utrwalania i rozpowszechniania nagich zwłok człowieka to w grę wchodziłaby odpowiedzialność za znieważenie zwłok z art. 262 \& 1 k.k Zob. R. Krajewski, Przestęsstwo utrwa- 
Przyznać należy, że kodeks karny kryminalizuje pierwszym rzędzie wszelkie działania odnoszące się do pornografii z udziałem małoletniego. Dla „purytanów", a tych przecież w społeczeństwie nie brakuje, może jednak okazać się pornografią obraz przestawiający nagiego amorka czy aniołka z zaznaczonymi męskimi genitaliami. Historia ludzkości w ogólności, a historia sztuki w szczególności, zna przecież przykłady zasłaniania brązowymi liśćmi klonowymi (wcale nie figowymi) genitaliów męskich na rzeźbach antycznych bądź renesansowych, czy zamalowywania takich przekazów nawet na obrazach uznanych mistrzów. W dużej mierze ściganie pornografii zdaje się być uwarunkowane religijnie, zwłaszcza przez trzy główne religie monoteistyczne, których duchowni uznają tego rodzaju przekazy za wyjątkowo grzeszne, negując to, że człowiek w swojej cielesności stworzony został przez Boga na jego obraz i podobieństwo ${ }^{156}$. Zauważyć przy tym wypada, że przekaz literacki, nawet najbardziej wyuzdany i obsceniczny, a także obrazy i rzeźby nie pociągają za sobą oskarżeń o pornografię. Organy ścigania, a także opinia publiczna dostrzegają pornografię głównie - jeśli nie wyłącznie - w treściach serwowanych filmów i przekazach internetowych.

Odpowiadając na pytanie, czy sztuka jest pornografią i jakie są ich wzajemne relacje, wypada przypomnieć, że funkcją normy prawnej nie jest dawanie definicji filozoficznych lub wybieranie między takimi definicjami, lecz ochrona bieżących interesów społecznych ${ }^{157}$. Generalna linia podziału między sztuką a pornografią przebiega więc między stoicką koncepcją sztuki jako imitacją natury, mającą do spełnienia funkcje wychowawcza, a koncepcją idealistyczno-epikurejską, ujmującą sztukę jako aktywność ducha, która spełnia rolę hedonistyczną. To przeciwstawienie rodzić musiało konflikt między treścią a formą. Doktryna chrześcijańska przejęła koncepcję stoicką, czyniąc ze sztuki funkcję religii i środek ekspresji dla gloryfikacji Boga. Rozwiązania te przyjęły świeckie teorie totalitarystyczne, głosząc hasła sztuki zaangażowanej. Koncepcja hedonistyczna nadal jednak jest żywa albo w rozwiązaniach odrodzenia, albo w koncepcjach romantycznych. Dla prawnika oznacza to konieczność uznania, że sztuka pozostaje poza sferą ocen moralnych lub też,

lania i rozpowszechniania wizerunku osoby nagiej lub osoby w trakcie czynności seksualnej, „Prokuratura i Prawo”, 2012, nr 5, s. 20-40. R. Krajewski wskazuje, także że pojęcie „osoba naga” dotyczy różnych postaci nagości w rozmaitych kontekstach zauważając jednak, że nie można popadać w tym zakresie w jakąkolwiek przesadę. Wizerunkiem osoby nagiej jego zdaniem będzie sytuacja, gdy taka osoba znajduje się in puris naturalibus, a także wówczas, gdy widać jej narządu płciowe oraz zasadniczo także i wtedy, gdy widoczne są pośladki takiej osoby oraz u kobiety piersi, chodź jak przyznaje ten autor w tym zakresie mogą zachodzić pewne wątpliwości, zob. R. Krajewski, op. cit., s. 20-40; J. Sobczak, M. Gołda-Sobczak, Prawo do informacji a utrwalanie wizerunku osoby nagiej bez jej zgody, „Etyka w mediach”, t. 8: Kodyfikacja czy modyfikacja norm, Opole 2011, s. $49-58$.

156 D. Øistein Endsjø, Seks a religia, Warszawa 2011, s. 15-18 i 395-416; R. Tannahill, Historia seksu, Warszawa 2013, s. 135-164 oraz 329-332.

157 M. Filar, Sztuka a zagadnienie..., s. 1432. 
że - tak jak każdy inny rodzaj ludzkiej aktywności - podlega takim ocenom i sądom. W konsekwencji powoduje to konieczność przyjęcia albo teorii ontologicznego wyłączania sztuki i sprośności albo teorię koegzystencji sztuki i sprośności. Według pierwszej z tych koncepcji sztuka nie może być sprośna, a więc nie może być pornografią. Tak więc dzieło pornograficzne nie jest sztuką. Zgodnie z drugą dopuszczalna jest możliwość koegzystencji dzieła sztuki ze sprośnością. W dalszej konsekwencji istnieje konieczność rozstrzygnięcia kwestii odpowiedzialności karnej za stworzenie, posiadanie, rozpowszechnianie dzieła sztuki, które jest sprośne, a więc pornograficzne. Tej teorii zdaje się hołdować obecnie obowiązujący kodeks karny, a także poprzedzające go kodyfikacje dotyczące odpowiedzialności karnej.

Z teorią ontologicznego wyłączania sztuki i sprośności współgra wychodząca $z$ innych przesłanek filozoficznych teoria esencjonalnej moralności sztuki, funkcjonująca w kilku wariantach. W literaturze wyróżnia się teorię puryfikacji estetycznej, puryfikacji inspiracyjno-celowościowej i teorię adekwatności socjalnej ${ }^{158}$. Elementem decydującym o puryfikacji, czyli oczyszczeniu przekazu, jest formalno-estetyczny poziom dzieła, a więc taki, w którym wartość artystyczna jest niepodważalna (teoria puryfikacji estetycznej). Oddanie oceny formalno-estetycznego poziomu dzieła w ręce prawników nie jest jednak rozwiązaniem najszczęśliwszym. Według zwolenników puryfikacji inspiracyjno-celowościowej czynnikiem oczyszczającym jest inspiracja i zamiar autora. Dociekanie istnienia tego zamiaru wydaje się niezwykle trudne, o ile nie wręcz niemożliwe. Według teorii adekwatności socjalnej kryterium puryfikacyjnym jest to, że dzieło sztuki nie może naruszać dobra prawnego ${ }^{159}$. Tak więc ta teoria, sformułowana przez R. Latagliatta, jest w gruncie rzeczy zgodna z teorią ontologicznego wyłączenia sztuki i sprośności.

Wspomniana wyżej teoria koegzystencji występuje w wariancie skrajnie moralistycznym bądź w teorii przewagi interesów. Pierwsza z tych koncepcji w przypadku występowania w dziele zarówno elementów artyzmu, jak i sprośności, przy ostatecznej ocenie dawała bezwzględny prymat tym ostatnim. Wynikało to z przekonania, że wszystko co sprośne, pornograficzne nie może być nigdy uznane za dzieło sztuki. Koncepcja teorii przewagi interesów występowała bądź w wariancie absolutnego priorytetu sztuki, bądź w wariancie teorii oceny kwantytatywnej. W pierwszym z tych wariantów przekaz artystyczny ważniejszy jest od zawartych w nim elementów pornograficznych, a więc jeśli dzieło ma wartość artystyczną, to jego sprośność jest z natury rzeczy wyłączona. W wariancie kwantytatywnym koniecznością jest ilościowa analiza interesu społecznego sprowadzającego się do zapewnienia swobody

158 Zob. M. Filar, Sztuka a zagadnienie..., s. 1434 odwołujący się do poglądów E. Battagliniego, L'arte e la tutela penale del pudowe, „Rivista Penale”, 1931, s. 462.

159 R. Latagliatt, Enciclopedia del ditto, Mediolan 1959, s. 64, cyt. za M. Filar, Sztuka a zagadnienie..., s. 1436. 
przepływu myśli i idei wyrażanych za pomocą przekazu artystycznego oraz interesu społecznego polegającego na zakazie rozpowszechnienia przekazów pornograficznych. Odmianą teorii kwantytatywnej jest koncepcja dobra publicznego. W polskiej doktrynie prawniczej ta ostatnia koncepcja była dość popularna $^{160}$.

W literaturze podkreśla się, że emocja estetyczna, jakiej doznaje się obcując z dziełem sztuki, oglądając obraz, czy czytając książkę, nie eliminuje innych emocji, w tym także emocji erotycznych. Niewątpliwie seks inspiruje twórców, zarówno wielkich pisarzy, jak i malarzy bądź figuratywnych rzeźbiarzy. W strofach Owidiusza, Rabelais'go, w Romeo i Julii Shakespeare'a, w Tristanie i Izoldzie, w Madame Bovary Gustava Flauberta, w niektórych fraszkach Jana Kochanowskiego, Ignacego Krasickiego, Kacpra Twardowskiego, w Dziejach grzechu i w Walce z szatanem Stefana Żeromskiego, w płótnach Rubensa, Boticellego, Tycjana, w Szale Władysława Podkowińskiego, w Mai nagiej Francesco Goi, dopatrzeć się by można nie tylko erotyzmu, sprośności, ale przy odpowiednim nasileniu złej woli także pornografii.

Wypada w tym miejscu zastanowić się, czy istotnie państwo środkami karnymi winno zwalczać przekazy literackie bądź wizualne kierując się jedynie tym, że w ich treści występuje opis stosunku seksualnego lub przedstawiona jest postać nagiej kobiety. Czy konieczne jest angażowanie organów ścigania i sądów w tym tylko celu, aby zadowolić garstkę, motywowanych najczęściej religijnie, polityków, duchownych czy działaczy społecznych dopatrujących się wszelkiego zła w nagiej postaci człowieka, w opisie aktu seksualnego bądź takowych pieszczot. Wydaje się, że na tak postawione pytania należy udzielić zdecydowanie odpowiedzi negatywnej, aczkolwiek przyznać należy, że przekaz pornograficzny może mieć i ma wpływ na rozwój psychofizyczny małoletniego. Pamiętać trzeba, że nie do uniknięcia jest zarówno dzisiaj, jak i był w przeszłości, wpływ takiego przekazu na młodą osobę, która zbyt wcześnie jak na swój wiek obejrzała jakieś obrazy, czy przeczytała chociażby Chłopów Władysława Reymonta, Popioły Stefana Żeromskiego ze sceną gwałtu w tomie drugim, XIII Księgę Pana Tadeusza czy nawet Krzyżowców Zofii Kossak. Zauważyć należy, że mimo olbrzymiej literatury dotyczącej problemu pornografii i odpowiedzialności za przestępstwa seksualne, także w postaci rozpowszechniania pornografii, pozostaje nadal bez odpowiedzi kwestia stosunku sztuki do przekazu pornograficznego ${ }^{161}$. Za szczególnie niebezpieczne zjawi-

160 Zwolennikiem tej teorii był A. Forel, Zagadnienia seksualizmu, Warszawa 1926, s. 140 oraz dopuszczający możliwość koegzystencji sztuki i pornografii L. Lernell, Przestępczość seksualna, [w:] Seksuologia społeczna, red. K. Imieliński, Warszawa 1977, s. 419 oraz A. Osęka, Lament nad upadkiem pornografii, „Kultura”, 1976, nr 31-33.

161 Zwrócić wypada uwagę na fakt, że nie ma jednej powszechnie obowiązującej i niebudzącej wątpliwości definicji sztuki. Zob. J. Sobczak, Wolność sztuki, twórczości satyrycznej i satyry..., s. 360-370. W kwestii pojmowania sztuki w niemieckiej doktrynie prawnej zob. niezwykle ważne 
sko wypada uznać chęć oddania oceny, czy określony przekaz jest sztuką oraz czy jako sztuka wypełnia znamiona pornografii, w ręce organów ścigania, a następnie sądów. Jednocześnie należy stwierdzić, że wytyczenie ścisłych granic sztuki, a także pornografii wydaje się być niemożliwe.

Wytyczenie granic wolności sztuki jest niezmiernie trudne, jeśli nie wręcz niemożliwe, gdyż z natury rzeczy artysta chce prowokować odbiorców, stara się w ten sposób przykuć ich uwagę, a także zyskać poklask. Nie wolno zapominać, że z wolnością ekspresji artystycznej łączy się konstytucyjnie gwarantowana wolność korzystania z dóbr kultury.

Wolność korzystania z dóbr kultury niesie w sobie zakaz tworzenia przez władze publiczne ograniczeń dostępu do nich. Wolność ta ma charakter szeroki, przez co może wchodzić w konflikt $\mathrm{z}$ innymi, potwierdzonymi w aktach prawa międzynarodowego, zagwarantowanych w konstytucjach wolnościami i prawami, w tym także z prawem własności. Ograniczenie w dostępie do dóbr kultury może wynikać z potrzeby ochrony tych dóbr i być dyktowane chęcią zachowania ich w stanie niepogorszonym. Akty prawa międzynarodowego niewątpliwie nakładają na państwa obowiązek tworzenia przepisów prawnych uniemożliwiających ograniczenie dostępu do dóbr kultury. Wolność ta ma charakter prawa podmiotowego, co w większości wypadków prowadzić powinno do możliwości formułowania skargi, także konstytucyjnej.

\section{Bibliografia}

Adler A., What's left? Hate Speech, Pornography and the Problem for Artistic Expression, „California Law Review”, 1996, t. 8, nr 6.

Aleksandrowicz A., Twórczość satyryczna Adama Naruszewicza, Warszawa 1964.

Andrejew I., Świda W., Wolter W., Kodeks karny z komentarzem, Warszawa 1973.

Arct M., Stownik wyrazów obcych, Warszawa 1938.

Bächli M., Das Recht am eigenen Bild, Basel - Genf - München 2002.

Bafia J., K. Mioduski K., Siewierski M., Kodeks karny. Komentarz, t. II, Warszawa 1987.

Bataille G., Erotyzm, Gdańsk 1999.

Bataille G., Historia erotyzmu, Warszawa 2008.

Battaglini E., L'arte e la tutela penale del pudowe, „Rivista Penale”, 1931.

Bazin A., Ontologia obrazu fotograficznego, [w:] idem, Film i rzeczywistość, Warszawa 1963.

Bem A. G., Teorya poezji polskiej z przykładami w zarysie popularnym analitycznodziejowym, Petersburg 1989.

Ben-Ze'ev A., Miłość w sieci. Internet i emocje, Poznań 2005.

Bereza A., Problemy teorii stylizacji w satyrze, Warszawa 1966.

i świetnie udokumentowane wywody M. M. Bieczyński, op. cit., s. 17-72. Por. także M. Filar, Sztuka a zagadnienie..., s. 1432 i n. 
Bieczyński M. M., Pojęcie sztuki w niemieckiej literaturze prawniczej i orzecznictwie Niemieckiego Sądu Konstytucyjnego, Opole 2012.

Bratuń M., Posłowie, [w:] D.-A.-F. de Sade, Justyna czyli nieszczęścia cnoty, Łódź 1987.

Brodziński K., O satyrze, Warszawa 1822.

Brodziński K., Pisma estetyczno-krytyczne, Wrocław 1964.

Buchwald-Pelcowa P., Satyra czasów saskich, Wrocław 1966.

Buchwald-Pelcowa P., Satyra, [w:] Literatura polska. Przewodnik encyklopedyczny, t. II, Warszawa 1985.

Budyn-Kulik B., Kulik M., Wolność działalności artystycznej jako okoliczność wytaczająca odpowiedzialność karna, [w:] Prawnokarne aspekty wolności, red. M. Mozgawa, Kraków 2006.

Bylok F., Rynek $i$ konsumpcja w społeczeństwie informacyjnym, [w:] Polskie doświadczenia w ksztaltowaniu spoleczeństwa informacyjnego. Dylematy cywilizacyjno-kulturowe, Warszawa 2002.

Cegielski H., Nauka poezji, Poznań 1879.

Chrzanowski I., Z dziejów satyry polskiej XVIII wieku, Warszawa 1909.

Chybiński O., Gutenkunst W., Świda W., Prawo karne. Część szczególna, Warszawa 1971.

Cieślak M., Polskie prawo karne zarys systemowego ujęcia, Warszawa 1994.

Dąbrowski J., ,"The medium is the message” - graffiti writing jako McLuhanowski środek przekazu, [w:] Street art. Między wolnościa a anarchia, red. M. Duchowski, E.A. Sekuła, Warszawa 2011.

Dee I.I.H., Satyra jako gra retoryczna, [w:] Nowa proza amerykańska. Szkice krytyczne, Warszawa 1983.

Dufour F.S.P., Historia prostytucji od czasów najdawniejszych do XX w., t. 1: Czasy przedchrześcijańskie, Gdynia 1997.

Dziemidok B., O komizmie, Warszawa 1967.

Eberle E. J. Arts Speech, http://1sr.nellco.org/cgi/viewcontent.cgi?article=1010\&context=rwu_fp.

Eck B.A., Nudity and Framing: Classifying Art., Pornography, Information and Ambiguity, ,Socjological Forum”, 2001, t. 16, nr 4.

Eco U., Historia piękna, Poznań 2005.

Ellliot R.C., The Power of Satire, Princeton 1960.

Elsberg J., Woprosy tieorii satiry, Moskwa 1957.

Fabiani B., Niziołki, łokietki, karlikowie: Z dziejów karlów nadwornych w Europie, Warszawa 1980.

Filar M., Pornografia. Studium z dziedziny polityki kryminalnej, Toruń 1977.

Filar M., Pornografia a sztuka, „Nowe Prawo”, 1978, nr 10.

Filar M., Pornografia, „Przegląd ustawodawstwa gospodarczego”, 1993, nr 8-9.

Filar M., Pornografia. Studium z dziedziny polityki kryminalnej, Toruń 1977.

Filar M., Przestępstwa przeciwko wolności, ,Nowa Kodyfikacja Karna. Kodeks Karny. Krótkie Komentarze", Warszawa 1998, z. 18.

Filar M., Przestępstwa seksualne w polskim prawie karnym, Toruń 1985.

Filar M., Sztuka a zagadnienie pornografii, „Nowe Prawo” 1978, nr 10. 
Filek B., Wizerunek osoby nagiej jako znamie przestepstwa $z$ art. 191 a $\$ 1$ k.k. „Prokuratura i Prawo", 2012, nr 7-8.

Filiciak M., Internet i rozrywka, [w:] Humanista w cyberprzestrzeni, red. F. Godzić, Kraków 1999.

Floryan W., Satyry Kasickiego a Boi-Leau, [w:] „Księga referatów zjazdu naukowego im. I. Krasickiego, Warszawa 1936.

Forel A., Zagadnienia seksualizmu, Warszawa 1926.

Frybes S., W krainie groteski. Problemy satyry galicyjskiej drugiej połowy XIX w., Warszawa 1979.

Galle H., Stylistyka i teorya literatury, Warszawa 1915.

Garczyński S., Anatomia komizmu, Poznań 1989.

Gardocka T., Czy w polskim prawie karnym potrzebny jest kontratyp sztuki?, „Palestra", 2015, z. 1-2.

Gardocki L., Europejskie standardy wolności wypowiedzi a polskie prawo karne, „Państwo i Prawo”, 1993, z. 3.

Gardocki L., Prawo karne, wyd. 17, Warszawa 2011.

Konwencja o ochronie Praw Człowieka i Podstawowych Wolności, t. I, red. L. Garlicki, Warszawa 2010.

Garlicki L., Komentarz do art. 30 Konstytucji w: Konstytucja Rzeczypospolitej Polskiej. Komentarz, red. L. Garlicki, t. III, Warszawa 2003.

Garlicki L., Uwagi do art. 9 i 10 Konwencji o Ochronie Praw Człowieka i Podstawowych Wolności, [w:] Konwencja o Ochronie Praw Człowieka i Podstawowych Wolności, t. I, red. L. Garlicki, Warszawa 2010.

Giddens A., Przemiany intymności. Seksualność, miłość i erotyzm we wspótczesnych społeczeństwach, Warszawa 2006, s. 146. Por. także A. Moye, Pornography, [w:] A. Metcalf, M. Humpries, The sexuality of Men, Londyn 1985.

Głowiński M., Okopień-Sławińska A., Sławiński J., Zarys teorii literatury, Warszawa 1986.

Grochowski R., Granice prawne i etyczne reklamy, Poznań-Opole 2010.

Grzędzielska M., Kostkiewiczowa T., Satyra, w: ,Słownik literatury polskiego Oświecenia”, red. T. Kostkiewiczowa, wyd. II, Wrocław - Warszawa - Kraków, 1996.

Hambura S., Muszyński M., Karta Praw Podstawowych z komentarzem, BielskoBiała 2001.

Hofmański P., Komentarz do wybranych przepisów Europejskiej Konwencji o ochronie praw człowieka i podstawowych wolności, w: „Standardy prawne Rady Europy. Tekst i komentarze. Prawo Karne”, Warszawa 1997.

Hopensztand D., Satyry Krasickiego w: „Stylistyka teoretyczna w Polsce”, red. K. Budzyk, Warszawa 1946.

Hordecka A., Mitologiczny świat reklam, Kraków 2002.

J. Warylewski J., Pasja czy obraza uczuć religijnych., Spór wokół art. 195 kodeksu karnego, w: L. Leszczyński, Ed. Skrętowicz, Z. Hołda (red.), „W kręgu teorii i praktyki prawa karnego", Lublin 2005.

Jan Paweł II, Encyklika Centesimus annus, pol. wyd. Wrocław 1991.

Jan Paweł II, Encyklika Veritatis Splendor, pol. wyd. Lublin 1995.

Jastrzębski Z., Kpina i terror, „Teksty”1972, z. 3. 
Jasudowicz T., Bluźnierstwo a kultura europejska: „pojedynek” między wolnościa ekspresji a wolnościa religii, „Studia Europejskie”, t. II, Warszawa 1998.

Jurecki K., Między erotyzmem a pornografia. O sztuce amerykańskiej lat osiemdziesiatych i dziewięćdziesiątych, w: „Sztuka a erotyka. Materiały sesji Stowarzyszenia Historyków Sztuki”, Warszawa 1995.

Kamiński I. C., Ograniczenia swobody wypowiedzi dopuszczalne w Europejskiej Konwencji Praw Człowieka. Analiza krytyczna, Warszawa 2010.

Kamiński I. C., Swoboda wypowiedzi w orzeczeniach Europejskiego Trybunatu Prawa Człowieka w Strasburgu, wyd. III, Kraków 2006.

Kamiński I.C., Ograniczenia swobody wypowiedzi dopuszczalne w Europejskiej Konwencji Praw Człowieka. Analiza krytyczna, Warszawa 2010.

Karasek S., Koncepcja wolności w encyklice „, Veritatis splendor” Jana Pawła II, Lublin 1994.

Kirk J. R., Szkodliwość pornografii, Gdańsk 1998.

Klimczyk W., Erotyzm ponowoczesny, Kraków 2008.

Klimczyk W., Erotyzm ponowoczesny, Kraków 2008.

Konwencja o Ochranie Praw Człowieka i Podstawowych Wolności sporządzona w Rzymie 4 listopada 1950r. zmieniona następnie Protokołami nr 3, 5 i 8 oraz uzupełniona Protokołem nr 2 ratyfikowana prze Polskę 15 grudnia 1992 Dz. U. 1993 Nr 61, poz. 284; uzup. Dz.U.1995, Nr 36, poz. 175 i 176; zm. Dz. U. 1995, Nr 36, poz. 177; 1998, Nr 147, poz. 962, uzup. Dz. U. 2001, Nr 23, poz. 266, 2003, Nr 42, poz. 364.

Kosonoga J., Karnoprawna ochrona intymnego wizerunku osoby, [w:] Studia i analizy Sądu Najwyższego, t. V, red. K. Ślebzak, Warszawa 2011.

Kowalczyk St., Koncepcja wolności odpowiedzialnej w encyklice Veritatis Splendor Jana Pawła II, [w:] „Wolność we współczesnej kulturze. Materiały V Światowego Kongresu Filozofii Chrześcijańskiej KUL - Lublin 20-25 sierpnia 1996”, Lublin 1997.

Kowalczyk St., Wolność natura i prawem człowieka, Sandomierz 2000.

Krajewski R., Przestepstwo utrwalania i rozpowszechniania wizerunku osoby nagiej lub osoby w trakcie czynności seksualnej, „, Prokuratura i Prawo”, 2012, nr 5.

Krakowski P., Z rozważań nad sztuka erotyczna, [w:] Sztuka a erotyka. Materiaty z sesji Stowarzyszenia Historyków Sztuki Łódź, listopad 1994, red. T. Hrankowska, Warszawa 1995.

Krakowski P., Z rozważań nad sztuka erotyczna, [w:] Sztuka a erotyka. Materiały sesji Stowarzyszenia Historyków Sztuki, Warszawa 1995.

Krawulska-Ptaszyńska A., Społeczne skutki upowszechnienia pornografii, „Ruch Prawniczy, Ekonomiczny i Socjologiczny", 1997, z. 1.

Krukowski A., Materialna treść czynu a okoliczności wyłączające bezprawność karna, „Nowe Prawo”, 1971, nr 12.

Krukowski J., Konstytucyjny system relacji między państwem a kościołem katolickim oraz innymi kościołami i związkami wyznaniowymi, [w:] Ustrój konstytucyjny Rzeczypospolitej Polskiej, t. X, red. E. Mojak, Lublin 2000.

Kunicka-Michalska B., Pornografia i wykorzystywanie nieletnich $w$ Internecie. Regulacje polskiego kodeksu karnego, ,Studia Prawnicze”, 2005, nr 4(166). 
Kunicka-Michalska B., Przestępstwa przeciwko wolności seksualnej i obyczajności popetniane za pośrednictwem systemu informacyjnego, Warszawa 2004.

Kusiak A., O historii kobiet, [w:] E. Pakszys, D. Sobczyńska, Humanistyka i pleć, t. II: Kobiety w poznaniu naukowym wczoraj i dziś, Poznań 1997.

Lamentowicz W., O wolnościach i ich granicach, [w:] Historia. Idee. Polityka, księga dedykowana profesorowi Janowi Baszkiewiczowi, red. F. Ryszka, Warszawa 1995.

Lanowski E., Nie igra się z humorem Prasa polityczna i jej rysuneczki, [w:] Humor europejski, Lublin 1994.

Lelental S., System prawa karnego, t. IV, cz. 2, Wrocław 1989.

Lemański J., Satyra polska. Antologia, Warszawa 1958.

Lernell L., Przestępczość seksualna, [w:] Seksuologia społeczna, red. K. Imieliński, Warszawa 1977.

Lewisohn C., Street Art.: The Graffiti Revolution, Tate Publishing 2008.

Lew-Starowicz Z., Seks w sieci i nie tylko, Kraków 2003.

Literatura polska, red. J. Krzyżanowski, Cz. Hernas, Warszawa 1985.

Literatura polska. Przewodnik encyklopedyczny, t. II, Warszawa 1985.

Lucie-Smith E., Erotism in Western Art, London 1972.

Makarewicz J., Kodeks karny z komentarzem, Lwów 1932.

Makarska M., Przestępstwa przeciwko wolności sumienia i wyznania w kodeksie karnym z 1997 roku, Lublin 2005, s. 177.

Manovich L., Język nowych mediów, Warszawa 2006.

Marek A., Waszczyński J., Obrona konieczna w prawie karnym na tle teorii i orzecznictwa Sądu Najwyższego, Warszawa 1979.

Markiewicz J., Kodeks karny z komentarzem, Lwów 1938.

Matuszewski K., Sade. Msza okrucieństwa, Gdańsk 2008.

Mayenowa M.R., Poetyka opisowa, Warszawa 1949.

McNair B., Seks, demokratyzacja pożądania i media, czyli kultura obnażania, Warszawa 2004.

Melosik Z., Ciało, tożsamość, władza. Teksty kulturowe jako konteksty pedagogiczne, Poznań-Toruń 1996.

Międzynarodowy Pakt Praw Obywatelskich i Politycznych otwarty do podpisu w Nowym Jorku dnia 19 grudnia 1966 r. ratyfikowany przez Polskę 3 marca 1977 r. Dz. U. 1977 Nr 38, poz. 167.

Mighet G., The Anatomy of Satire, Princeton 1962.

Mizielińska J., Płeć, ciało, seksualność od feminizmu do teorii queer, Kraków 2006.

Mozgawa M., Kodeks karny. Praktyczny komentarz, Warszawa 2010.

Mozgawa M., Przestępstwa przeciwko wolności, [w:] Kodeks karny. Praktyczny komentarz, red. M. Mozgawa, Warszawa 2010.

Nalewajko J. J., Kubiak R., Sztuka jako okoliczność wyłączająca bezprawność?, „Palestra", 2000, nr 9-10.

Nowak M., Kierc K., Internet z perspektywy nauk społecznych, [w:] Społeczna przestrzeń Interentu, red. D. Batorski, M. Marody, A. Nowak, Warszawa 2006.

Nowak-Dłużewski J., Satyra polityczna konfederaci targowickiej i sejmu grodzieńskiego, Warszawa 1935.

Nowak-Dłużewski J., Satyra polityczna Sejmu Czteroletniego, Warszawa 1933. 
Nowicki M. A. (wprowadzenie i tłumaczenie), Karta Podstawowych Praw Unii Europejskiej, Zakamycze 2001.

Øistein Endsjø D., Seks a religia, Warszawa 2011.

Olechnicki K., Fotoblogi, pamiętniki z opcja przekazu. Fotografia i fotoblogerzy w kulturze konsumpcyjnej, Warszawa 2009.

Orzeczenie ECHR Hachette Filipacchi Associés przeciwko Francji, wyrok z dnia 12 listopada 2007 r., skarga nr 71111/01, http://hudoc.echr.coe.int/eng?i=00181066.

Orzeczenie ECHR Handyside przeciwko Wielkiej Brytanii, skarga nr 5493/72, wyrok z dnia 7 grudnia 1976 r., http://hudoc.echr.coe.int/eng?i=001-57499.

Orzeczenie ECHR Müller i inni przeciwko Szwajcarii, wyrok z dnia 24 maja 1988, skarga nr 10737/84, http://hudoc.echr.coe.int/eng?i=001-57487.

Orzeczenie ECHR Otto-Preminger-Institut przeciwko Austrii, wyrok z dnia 20 września 1994 r., skarga nr 13470/87, http://hudoc.echr.coe.int/eng?i=001-57897.

Orzeczenie ECHR Sunday Times przeciwko Wielkiej Brytanii, wyrok z dnia 26 kwietnia 1979 r., skarga nr 6538/74, http://hudoc.echr.coe.int/eng?i=001-57584.

Orzeczenie ECHR Wingrove przeciwko Wielkiej Brytanii, wyrok z dnia 25 listopada 1996 r., skarga nr 17419/90, http://hudoc.echr.coe.int/eng?i=001-58080.

Osęka A., Lament nad upadkiem pornografii, „Kultura”, 1976, nr 31-33.

Pakszys E., Feministyczna rewindykacje wobec nauk o życiu albo o roli płci/rodzaju w poznaniu biologicznym, [w:] E. Pakszys, D. Sobczyńska, Humanistyka i płeć, t. II Kobiety w poznaniu naukowym wczoraj i dziś, Poznań 1997.

Paprzycki R., Graj szatanie, ,Rzeczpospolita” z 21 września 2000 r.

Paprzycki R., Prawnokarna analiza zjawiska satanizmu w Polsce, Zakamycze 2002.

Parker H.N., Love's body anatomized: the ancient erotic handbooks and the rhetoric of sexulity, [w:] Pornography and representation in Ancient Rome, red. A. Richlin, New York 1992.

Peiper L., Komentarz do kodeksu karnego, Kraków 1936.

Petersen J. R., Stulecie seksu. Historia rewolucji seksualnej 1900-1999 wedtug „Playboya”, Poznań 2002.

Piskorski J., Kontratyp sztuki?, [w:] Wokół problematyki prawnej zabytków i dziet sztuki, red. W. Szafrański, Poznań 2007.

Piwocki K., Dzieje sztuki w zarysie, t. 2, Warszawa 1977.

Pokrzywniak J.T., J. Goryczewski. Thumacz, satyryk i krytyk; ,Satyra prawdę mówi” czyli rzecz o fatszywych przesłankach, „Pamiętnik Literacki”, 1984, z. 4.

Prause N., Steele D.R., Stanley C., Sabatinelli D., Hajcak G., Modulation of late positive potentials by sex ual images inconsistent with sex addiction, „Biological Psychology", 2015, nr 109.

Prawa człowieka, geneza, koncepcje, ochrona, red. B. Banaszak, Wrocław 1993.

Praz M., Zmysty, śmierć i diabeł w literaturze romantycznej, Gdańsk 2010.

Projekt Kodeksu Karnego Komisji Kodyfikacyjnej Rzeczypospolitej Polskiej. Uzasadnienie części szczególnej, t. V, z. 4, Warszawa 1930.

Promiński M., Gorzkie migdały poezji, „Kurier Literacko-Naukowy”, 1936, nr 28.

Pytko K., Staba, piękna czy gorsza?, [w:] Pleć - sex-gender. Trzecia, czwarta, piąta pteć, Warszawa 2014. 
Quintero R., A Companion to Satire, Blackwell Publishing.

Reiner B., Staszewski M., Zagadnienia wolności sumienia $i$ wyznania $w$ projekcie k.k., „Państwo i Prawo”, 1963, nr 8-9.

Reinsberg C., Obyczaje seksualne starożytnych Greków, Gdynia 1998.

Roch-Bajorek G., Władcy ust. Granice swobody wypowiedzi polityków $i$ wypowiedzi o politykach $w$ świetle orzecznictwa Europejskiego Trybunału Praw Człowieka w Strasburgu, Toruń 2010.

Rosenblatt J., Ustawa karna o zbrodniach, wystepkach i przekroczeniach, cz. I, Kraków 1914.

Rotfeld A. D. (red.), Prawa Człowieka. Międzynarodowe zobowiązania Polski (Wybór dokumentów), red. A. D. Rotfeld, Warszawa 1989.

Rougemont D. de, Mitość a świat kultury zachodniej, Warszawa 1968.

Satyra, [w:] Stownik literatury polskiej XIX wieku, red. J. Bachórz, A. Kowalczykowa, Wrocław-Warszawa-Kraków 1991.

Sawecka H., Humor i satyra, [w:] Humor europejski, red. M. Abramowicz, D. Bertrand, T. Strużyński, Lublin 1994.

Schmoller K., Strafrecht und die Freiheit der Kunst. Die Suche nach einer Grenze, [w:] Art goes Law, Dialoge zum Wechselspiel zwischen Kunst und Recht, red. D. Pauger, Böhlau-Wien 2005.

Shattuck R., Mediated Sex. Pornography \& Postmodern Culture, Londyn-Nowy Jork-Sydney-Auckland 1996.

Shattuck R., Zakazana wiedza. Od Prometeusza do pornografii, Kraków 1999.

Sieczkowski G., Cały ten seks. Kroniki podkasane, Warszawa 2008.

Sikora S., Fotografia między dokumentem a symbolem, Izabelin 2004.

Skwarczyńska S., O pojęciu literatury stosowanej, [w:] Szkice i felietony, „Rocznik Literacki" Warszawa 1937-1938.

Skwarzyński M., Bluźnierstwo w świetle standardów ochrony praw człowieka, [w:] Odpowiedzialność karna artysty za obrazę uczuć religijnych, red. F. Ciepły, Warszawa 2014.

Słownik terminów literackich, red. J. Sławiński, Wrocław 1988.

Słowiński M., Błazen dzieje postaci i motywu, Warszawa 1993.

Słownik języka polskiego, t. III, red. M. Szymczak, Warszawa 1989.

Stownik literatury polskiego Oświecenia, wyd. II, Wrocław-Warszawa-Kraków 1996.

Słownik literatury polskiej XIX wieku, red. J. Bachusz, A. Kowalczykowa, Wrocław-Warszawa-Kraków 1997.

Słownik wyrazów obcych PWN, Warszawa 1978.

Sobczak J., Gołda-Sobczak M., Prawo do informacji a utrwalanie wizerunku osoby nagiej bez jej zgody, „Etyka w mediach”, vol. 8: Kodyfikacja czy modyfikacja norm, Opole 2011.

Sobczak J., Piesiewicz P., Graffiti - dzieło sztuki czy forma dewastacji obiektów architektonicznych, [w:] Street art. Między wolnościa a anarchia, red. M. Duchowski, E. A. Sekuła, Warszawa 2011.

Sobczak J., Prawo do prywatności a wolność słowa i druku, [w:] Wolności i prawa jednostki oraz ich gwarancje w praktyce, red. L. Wiśniewski, Warszawa 2006. 
Sobczak J., Prawo prasowe. Komentarz, Warszawa 2008.

Sobczak J., Ramy prawne satyry politycznej, [w:] Fenomen radości, red. A. Grzegorczyk, J. Grad, P. Szkudlarek, Poznań 2007.

Sobczak J., Sobczak W., Uwagi do art. 10 Karty Praw Podstawowych Unii Europejskiej, [w:] Karta Praw Podstawowych Unii Europejskiej, red. A. Wróbel, Warszawa 2013.

Sobczak J., Swoboda wypowiedzi w orzecznictwie Trybunatu Praw Człowieka w Strasburgu, cz. I, „Ius Novum”, 2007, nr 2-3.

Sobczak J., Swoboda wypowiedzi w orzecznictwie Trybunału Praw Człowieka w Strasburgu, cz. II „Ius Novum”, 2007, nr 4.

Sobczak J., Uwagi do art. 11 Karty Praw Podstawowych Unii Europejskiej, [w:] Karta Praw Podstawowych Unii Europejskiej, red. A. Wróbel, Warszawa 2013.

Sobczak J., Uwagi do art. 13 Karty Praw Podstawowych Unii Europejskiej, [w:] Karta Praw Podstawowych Unii Europejskiej, red. A. Wróbel, Warszawa 2013.

Sobczak J., [w:] Kodeks karny. Komentarz, red. R. Stefański, Warszawa 2015.

Sobczak J., Wolność ekspresji artystycznej, [w:] Media - czwarta władza?, t. 2, red. M. Gołda-Sobczak, W. Machura, J. Sobczak, Poznań-Opole 2011.

Sobczak J., Wolność ekspresji artystycznej. Standardy europejskie i rzeczywistość polska, [w:] Rada Europy a przemiany demokratyczne $w$ państwach Europy Środkowej $i$ Wschodniej w latach 1989-2009, red. J. Jaskiernia, Toruń 2010.

Sobczak J., Wolność sztuki, twórczości artystycznej i satyry. Czy istnieje kontratyp sztuki? Regulacje europejskie a rozwiazania polskiego systemu prawnego, [w:] Uniwersalny $i$ regionalny wymiar ochrony praw czlowieka. Nowe wyzwanianowe rozwiązania, t. III, red. J. Jaskiernia, Warszawa 2014.

Sobczak J., Wolność środków społecznego przekazu czy wolność ekspresji w orzecznictwie Trybunatu Sprawiedliwości w Strasburgu, [w:] Kulturowe instrumentalium wolności. Etyka i prawo, red. R. Paradowski, Poznań 2015.

Sobczak J., Wolność wypowiedzi prasowej a zniewaga, „Środkowoeuropejskie Studia Polityczne", 2012, nr 1.

Sova D. B., 125 zakazanych filmów. Historia cenzury w kinie, Warszawa 2006.

Starowicz Z. L., Seksuologia sadowa, Warszawa 2000.

Stępień T., O satyrze, Katowice 1996.

Sznajderman M., Błazen. Maski metafory, Gdańsk 2000.

Ślęzak I., Seks i erotyka w sieci, czyli czego poszukuja internauci, [w:] Oblicza Internetu. Opus Univerasale. Kulturowe, edukacyjne i technologiczne przestrzenie Internetu, red. M. Sokołowski, Elbląg 2008.

Śliwiński S., Prawo karne materialne. Część szczególna, Warszawa 1948.

Tannahill R., Historia seksu, Warszawa 2013.

Taylor G. R., The Science of Life. A Picture History of Biology, New York-Toronto 1963.

Tomaszewski B., Poetyka, Poznań 1935.

Psychologia, red. T. Tomaszewski, Warszawa 1979.

Toscani O., Reklama uśmiechnięte ścierwo, Warszawa 2009.

Tymiec R., Satyra a ochrona czci w polskim prawie cywilnym, [w:] Wybrane zagadnienia prawa cywilnego, red. M. Warciński, K. Zaradkiewicz, Warszawa 2006. 
Uchwała Sądu Najwyższego z dnia 29 października 2012 r., I KZP 12/12, OSNKW 2012, z. 11, poz. 112.

Uniwersalny słownik języka polskiego, red. S. Dubisz, Warszawa 2003.

Warylewski J., Pasja czy obraza uczuć religijnych? Spór wokót art. 196 kodeksu karnego, [w:] W kręgu teorii i praktyki prawa karnego. Księga poświęcona pamięci Profesora Andrzeja Wąska, Lublin 2005.

Warylewski J., Pornografia - próba definicji, [w:] Pornografia, red. M. Mozgawa, Warszawa 2011.

Warylewski J., Pornografia, [w:] idem, Przestęstwa przeciwko dobrom indywidualnym, „System Prawa Karnego”, t. X, Warszawa 2012.

Warylewski J., Przestępstwa przeciwko wolności seksualnej i obyczajowości. Rozdziat XXV kodeksu karnego. Komentarz, Warszawa 2001.

Warylewski J., Przestępstwa seksualne, Gdańsk 2001.

Warylewski J., Sprośne rysunki, [w:] Fascynujące ścieżki filozofii prawa, red. J. Zajadło, Warszawa 2008.

Warylewski J., uwagi do art. 202 k. k., [w:] Kodeks karny. Część szczególna, komentarz do art. 117 - 221, t. I, 4 wyd., red. A. Wąsek, R. Zawłocki, Warszawa 2010.

Warylewski J., [w:] Kodeks karny. Komentarz, wyd. 2, red. R. A. Stefański, Warszawa 2015.

Warzynica-Zalewska E., Pojęcie humoru, jego rola w powieściopisarstwie polskim drugiej połowy XIX w., „Przegląd Humanistyczny”, 1992, nr 6.

Wasilewski P., Wolność prasowej wypowiedzi satyrycznej. Studium cywilistyczne na tle porównawczym, Warszawa 2012.

Wąsek A., Przestęstwa przeciwko przekonaniom religijnym ,de lege lata” $i$,de lege frerenda”, „Państwo i Prawo”, 1995, nr 7.

Welzel H., Das Deutsche Strafrecht. Eine systematische Darstellung, Berlin 1969.

Wielka Encyklopedia Powszechna PWN, t. XXIV, Warszawa 2004.

Wielka Encyklopedia Powszechna, t. X, Warszawa 1967.

Williams L., Hard Core. Władza, przyjemność i ,szaleństwo widzialności”, Gdańsk 2010.

Williams L., Seks na ekranie, Gdańsk 2013.

Wilska M., Błazen na dworze Jagiellonów, Warszawa 1998.

Wiśniewski L., Prawo a wolność człowieka - pojęcie i konstrukcja prawna, [w:] Podstawowe prawa jednostki i ich sadowa ochrona, red. L. Wiśniewski, Warszawa 1997.

Wojciechowska J., [w:] A. Wąsek, R. Zawłocki, Kodeks karny. Część szczególna, wyd. 4, Warszawa 2010.

Wojciechowska J., [w:] A. Wąsek, Kodeks karny. Komentarz, t. 1, Warszawa 2010.

Wojtyczek K., Granice ingerencji ustawodawczej w sfere praw człowieka w Konstytucji RP, Kraków 1991.

Wolter W., O kontratypach i braku społecznej szkodliwości czynu, „Państwo i Prawo", 1963, nr 10.

Woźnikowski W., Pamflet polityczny w czasach Stanisława Augusta, Wrocław 1973.

Wróbel W., Opinia prawna o rzadowym projekcie ustawy o zmianie ustawy - Kodeks karny, ustawy - Kodeks postepowania karnego, ustawy - Kodeks karny wyko- 
nawczy, ustawy - Kodeks karny skarbowy oraz niektórych innych ustaw, druk sejmowy nr 1394.

Wróbel W., [w:] Kodeks karny. Część szczególna, t. II, wyd. 4, red. A. Zoll, Warszawa 2013.

Wróbel Z., Erotyzm w literaturze nowożytnej, Łódź 1987.

Wróblewska E., Satyra polityczna Wielkiej Emigracji, Poznań 1977.

Wyrok Izby Drugiej Karnej Sądu Najwyższego w pełnym składzie z dnia 26 marca 1925 r., II K 3/1925, Zbiór Orzeczeń Sądu Najwyższego, Orzeczenia Izby Karnej rok 1925, Warszawa 1926.

Wyrok Sądu Najwyższego z dnia 23 listopada 2010 r. IV K.K. 173/10, LEX nr 667510, glosa aprobująca M. Budyn-Kilk, LEX/L 2011.

Wyrok Sądu Najwyższego z dnia 27 lutego 1934 r., 2 K 42/34, OSP 1934, z. 2, poz. 23.

Wyrok Sądu Najwyższego z dnia 5 lipca 1938 r., 1 K 1895/37, OSNIK 1939, z. IV, poz. 81.

Wyrok SN z 17 lutego 1993 r., sygn. II KRN 24/92, „Wokanda”, 1993, nr 10.

Wyrok Trybunału Konstytucyjnego z 12 stycznia 1999 r., sygn. P 2/98.

Wyrok Trybunału Konstytucyjnego z 12 stycznia 2000 r., P11/99.

Wyrok Trybunału Konstytucyjnego z 7 lutego 2001 r., K27/00, OTK ZU 2001, Nr 2, poz. 29.

Wyrzykowski M., Granice praw i wolności - granice władzy, [w:] Obywatel, jego wolności i prawa, oprac. B. Oliwa-Radzikowska, Warszawa 1998.

Zoll A., „Pozaustawowe” okoliczności wytaczające odpowiedzialność karna w świetle konstytucyjnej zasady podziału władzy, [w:] W kręgu teorii i praktyki prawa karnego. Księga poświęcona pamięci prof. Andrzeja Waska, red. L. Leszczyński, Ed. Skrętowicz, Z. Hołda, Lublin 2005.

Zoll A., Stosunek kontratypów do ustawowej określoności czynu, „Państwo i Prawo”, $1975, \mathrm{nr} 4$.

\section{FREEDOM OF ARTISTIC EXPRESSION. EUROPEAN REGULATIONS AND THE SOLUTIONS FOUND IN THE POLISH LEGAL SYSTEM}

Summary

In the Polish Constitution Act (1997), freedom of artistic expression seems to be of secondary importance. It is mentioned as one of the economic, social and cultural freedoms and rights in the Second Chapter of the Constitution ("Civil Freedoms, Rights and Obligations"). It can be found in Article 73 alongside the freedom of scientific research, the freedom of education, and the freedom of presenting the results of the scientific research.

All the aforementioned freedoms mentioned in Article 73 of the Constitution are considered to be substantive rights, meaning that (1) the scope of their inquiry is not 
limited by the dispositions implicated by Article 81 of the Constitution, and (2) once they are not obeyed, one may lodge a constitutional complaint.

Consequently, the limits of those freedoms are delineated exclusively by the contents of Article 31 of the Constitution (by Paragraph 3 of this Article in particular). Furthermore, the fact that freedom of artistic expression is mentioned in Article 73 implies the interdiction of any restriction of that freedom.

Freedom of artistic expression, however, is not absolute. Since artistic activity may threaten someone's dignity, privacy, religious freedom, or a freedom of conscience, there might actually be limits to this freedom.

The European Court of Justice has repeatedly emphasized the opinion that all the freedoms of expression, regardless of the content and the means of communication, are guaranteed by Article 10 of the Convention for the Protection of Human Rights and Fundamental Freedoms. Moreover, the Court, while interpreting Article 10 of the Convention, paid close attention to the issue of critique and its limits. However, the issue of political satire has never been raised by the Court.

As a result, Polish judicature and doctrine are left to their own devices and have no European legal advice on the matter. On the one hand, satirists are allowed to ridicule people's opinions and attitudes. On the other hand, they are to obey certain rules of critique. The paper provides some examples of cases supporting the thesis that although there are no explicit European standards on political and religious satire, some general standards in the matter were established within the European Council's legal system.

\title{
LA LIBERTÉ D'EXPRESSION ARTISTIQUE. LES RÈGLEMENTS EUROPÉENS VIS-À-VIS DES NORMES DU SYSTÈME JURIDIQUE POLONAIS
}

\author{
Résumé
}

La liberté d'expression artistique occupe une position plutôt basse dans le catalogue des droits de l'homme et des libertés énoncés dans la Constitution de la République de Pologne promulguée en 1997. Ses auteurs ont mis la liberté d'expression dans le même groupe que la liberté de la recherche scientifique, la liberté d'accès à la culture, la liberté de l'enseignement et la liberté de publier les résultats de recherche. Tous ces droits sont contenus dans l'article 73 dans le cadre des libertés et des droits économiques, sociaux et culturels, dans le chapitre II de la Constitution : Libertés, droits et devoirs de l'homme et du citoyen.

Les libertés mentionnées dans l'art. 73 de la Constitution ont le caractère des droits, subjectifs ce qui permet de formuler une plainte constitutionnelle en cas de violation de ces droits, et l'étendue de ces libertés n'est pas limitée par les dispositions de l'article 81 de la Constitution. Ainsi, les limites de ces libertés ne peuvent être désignées que par la disposition de l'article 31 de la Constitution - en particulier 
son alinéa 3. L'article 73 de la Constitution, garantissant la liberté de création artistique ainsi que de recherche scientifique, interdit aux pouvoirs publics d'entreprendre des actions visant à limiter ou supprimer la liberté de recherche, la liberté d'expression artistique et la liberté de publier les résultats de recherche. Toutefois, la liberté d'expression artistique, qui est ancré dans la Constitution, n'a pas de caractère absolu et elle peut être soumise à certaines restrictions légales. Les activités artistiques peuvent également sérieusement menacer les autres - ne respectant pas leur dignité, leur vie privée, leur liberté de conscience et de religion.

La Cour européenne des droits de l'homme a souligné à plusieurs reprises que la protection de la liberté d'expression, résultant de l'art. 10 de la Convention européenne, couvre toutes sortes d'expressions des pensées et des opinions ou des informations, quel que soit leur contenu et le mode de communication. En interprétant l'art. 10 de la Convention européenne des droits de l'homme et des libertés fondamentales, la Cour européenne des droits de l'homme de Strasbourg s'est exprimé très largement sur les limites de la critique et son étendue - d'ailleurs, dans différents contextes. Mais la Cour européenne n'a pas traité une question de satire politique. Alors, dans ce champ, la jurisprudence et la doctrine polonaise sont restées seules et privées d'indications découlant de la loi européenne. Le législateur reconnaît le droit d'un auteur satirique de présenter d'une manière ridicule des attitudes et opinions d'autres personnes. Cependant, l'auteur ne peut pas échapper à l'obligation de choisir une forme appropriée de la critique.

Bien que la Cour européenne des droits de l'homme de Strasbourg n'ait pas développé - à ce jour - des règles pour la satire, y compris politique et religieuse, ses jugements cités ci-dessus conduisent à la conclusion que, dans le système juridique du Conseil de l'Europe, une certaine norme concernant les déclarations relatives aux symboles religieux et généralement aux questions de la foi a été développée. 